\title{
ELECTROREFINING OF HIGH PURITY MANGANESE
}

by

\author{
Xiangzhi Cao
}

B.Eng., Central South University, China, 2014

\section{A THESIS SUBMITTED IN PARTIAL FULFILLMENT OF THE REQUIREMENTS FOR THE DEGREE OF}

MASTER OF APPLIED SCIENCE

in

THE FACULTY OF GRADUATE AND POSTDOCTORAL STUDIES

(Materials Engineering)

THE UNIVERSITY OF BRITISH COLUMBIA

(Vancouver)

October 2016

(C) Xiangzhi Cao, 2016 


\begin{abstract}
Manganese is an important industrial metal used as an additive for production of various steels, non-ferrous alloys, electronic components and special chemicals. The traditional electrowinning process is not suitable for the production of high-purity manganese. Therefore, a novel ion exchange - electrorefining process for production of high-purity manganese is proposed to solve the problems.
\end{abstract}

The ammonium chloride - manganese chloride electrolyte was selected as the most promising for refining. The physical properties of the electrolyte were first studied. The density increases when increasing concentrations of the ammonium chloride and manganese chloride. The maximum electrical conductivity is obtained with high concentrations of ammonium chloride and high temperature. Viscosity is minimized by high temperature and by low concentrations of manganese chloride.

The electrorefining process introduces impurities into the anolyte from the dissolving anode. The purification of the electrolyte by cementation and ion exchange were investigated. This thesis reports the uptake of copper, nickel, cobalt, cadmium, zinc and manganese from manganese chloride solution onto the chelating resin Lewatit ${ }^{\circledR}$ MDS TP220 and Purolite S930Plus in batch and column experiments. The results demonstrate the ability for Lewatit ${ }^{\circledR}$ MDS TP220 to remove contaminants to an extent satisfying the quality criteria required for electrorefining. However, cementation of impurities by manganese powder and ion exchange with Purolite S930Plus are not suitable for purification to satisfy the quality criteria. 
In the electrorefining process, the individual and synergistic effects of selected impurities on manganese deposit quality were first investigated. The purity of manganese deposit did not change significantly in the presence of impurities. An addition of $0.15-5.0 \mathrm{mg} / \mathrm{Zn}^{2+}$ to the catholyte increases the cathodic current efficiency. The parameters of current density, deposition time, and cathode usage frequency were investigated. Current density, deposition time and cathode usage frequency could affect current efficiency, specific energy consumption and surface morphology. With increasing the current density, the cathodic current efficiency first increased, reached a maximum value and then decreased. With increasing deposition time from 24 hours to 48 hours, the manganese current efficiency decreased and the deposit became more dendritic. The more times the cathode was used, the lower the current efficiency. 


\section{Preface}

This thesis is original, unpublished, independent work by the author, Xiangzhi Cao. 


\section{Table of Contents}

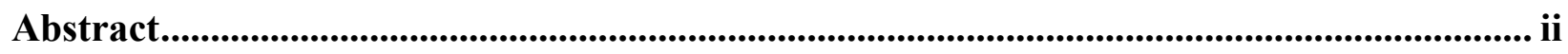

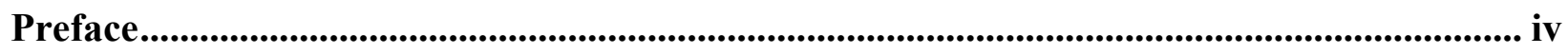

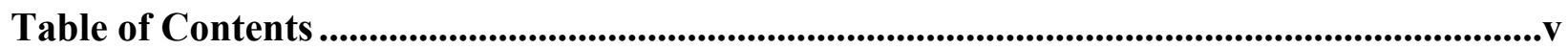

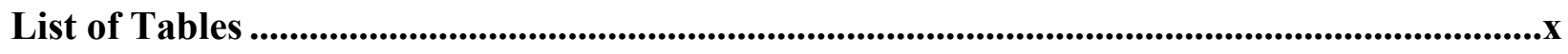

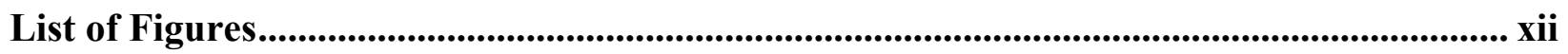

List of Symbols .................................................................................................................................... xvii

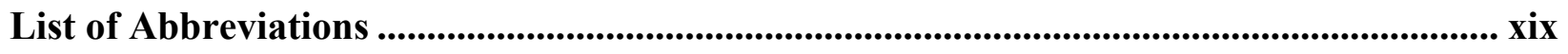

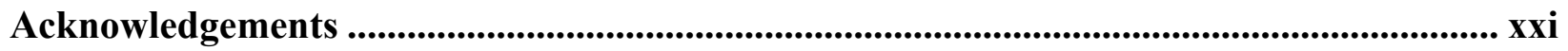

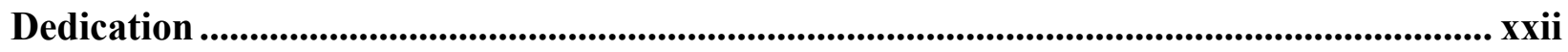

Chapter 1: Introduction ..........................................................................................................................1

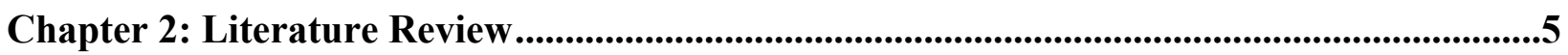

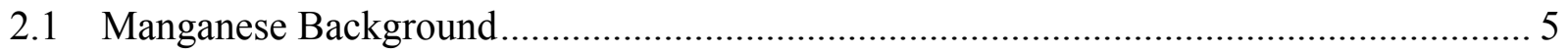

2.1.1 Physical Properties of Manganese .................................................................. 5

2.1.2 Chemical Properties of Manganese ................................................................ 6 
2.1.3 The Applications of Manganese

2.2 Previous Studies on Manganese Separation and Recovery from Solutions ……….......... 8

2.2.1 Sulfide Precipitation of Metals from $\mathrm{Mn}^{2+}$ Solution.............................................. 9

2.2.2 Hydroxide Precipitation of Metals from $\mathrm{Mn}^{2+}$ Solution ........................................... 11

2.2.3 Adsorption and Ion Exchange from $\mathrm{Mn}^{2+}$ Solution .............................................. 13

2.2.4 Solvent Extraction from $\mathrm{Mn}^{2+}$ Solution ................................................................ 17

2.2.4.1 D2EHPA-phosphoric Acid Extractant ............................................................ 18

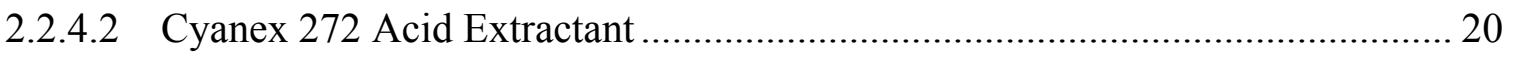

2.2.4.3 PC-88A Acid Extractant ......................................................................... 22

2.3 Previous Studies on Manganese Recovery from Solution .............................................. 23

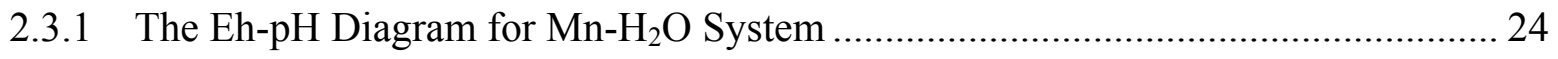

2.3.2 Manganese Electrowinning from Sulfate Media …................................................. 26

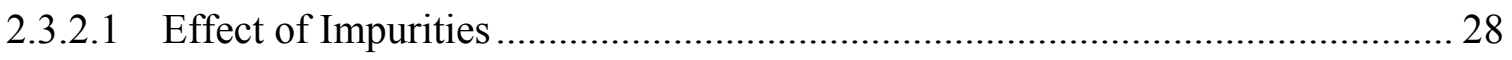

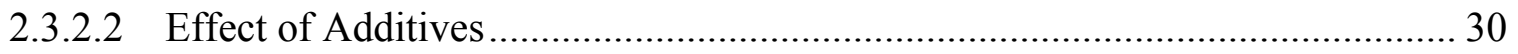

2.3.3 Manganese Electrowinning from Chloride Media.................................................. 32 


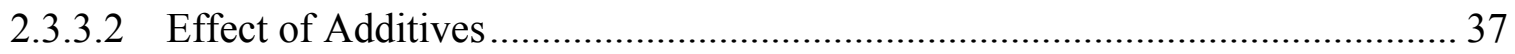

Chapter 3: Physical Properties of Manganese Electrorefining Electrolytes .............................39

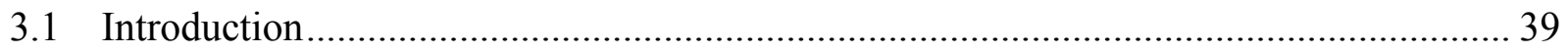

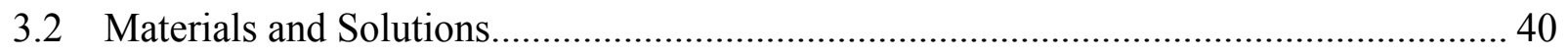

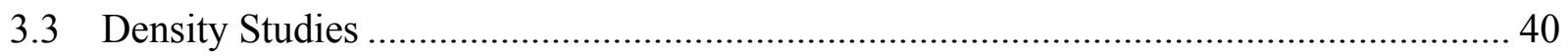

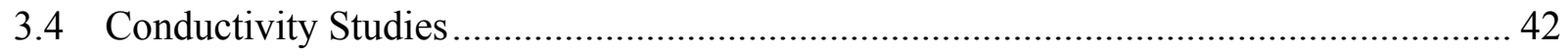

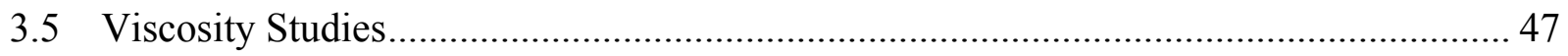

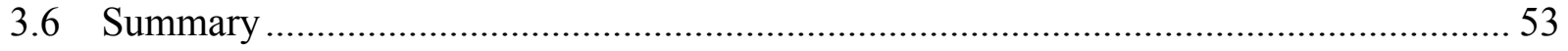

Chapter 4: Purification by Cementation and Ion Exchange .........................................................54

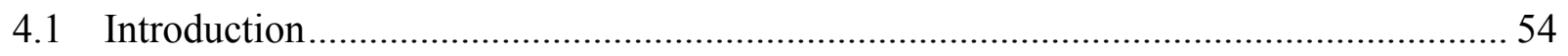

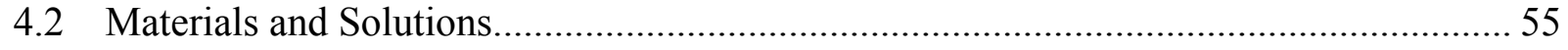

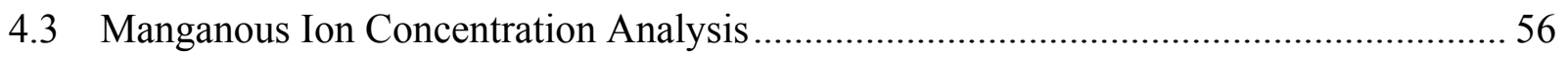

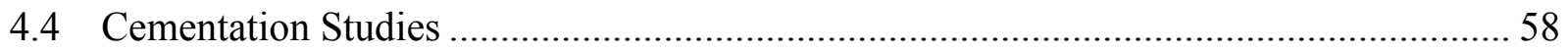

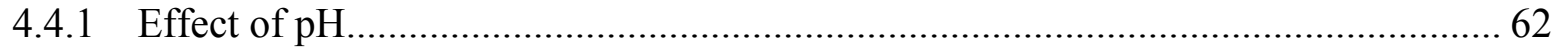


4.5 Equilibrium Ion Exchange Studies

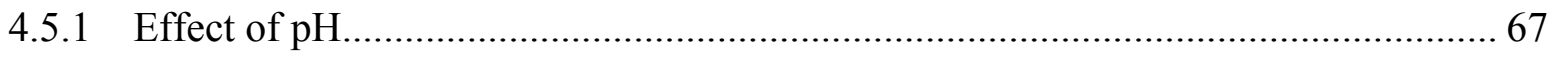

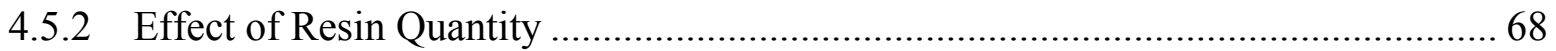

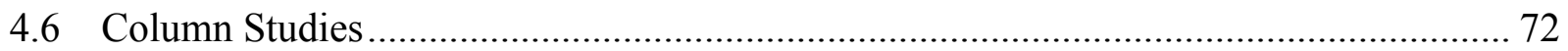

4.6.1 Effect of Resin Quantity ........................................................................ 74

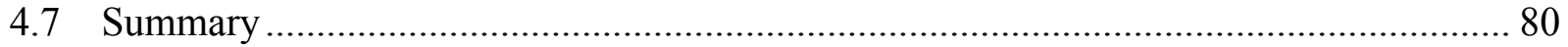

Chapter 5: Electrorefining of Manganese .....................................................................................82

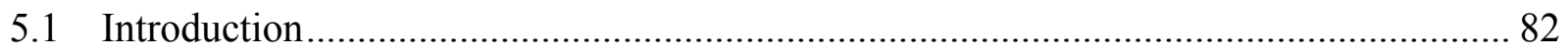

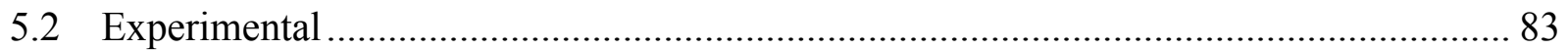

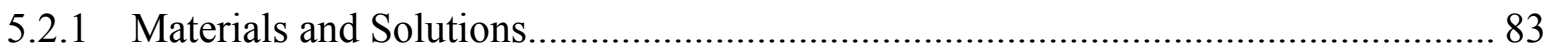

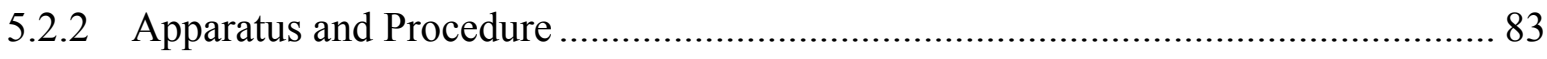

5.2.3 Evaluation Factors and Analytical Methods ….............................................. 87

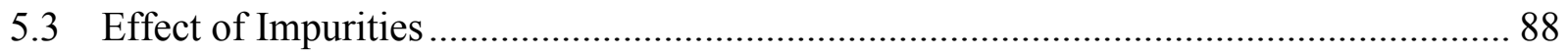

5.4 Effect of Operation Conditions ......................................................................... 95

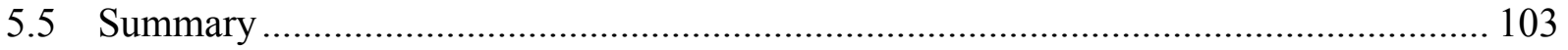




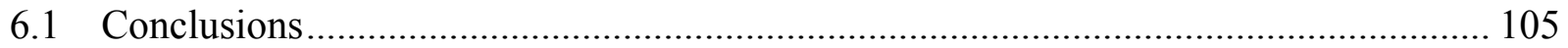

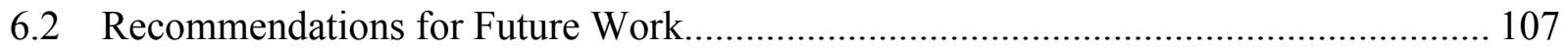

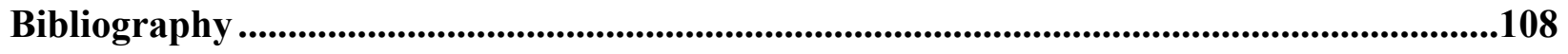

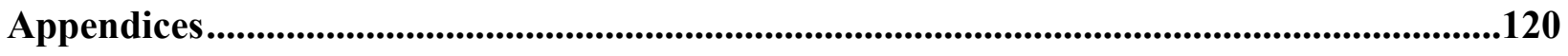

Appendix A Calibrations for Conductivity Meter and Viscometer .................................... 120

Appendix B XRD Patterns................................................................................... 121 


\section{List of Tables}

Table 2.1 Basic information and classifications of manganese[10], [11] ............................... 5

Table 2.2 2011-2013 Mine production (Unit: thousand metric tons)[16] ............................... 8

Table 2.3 Heavy metal removals using chemical precipitation[21] .................................... 12

Table 2.4 Resin metal loading selectivity orders in weakly acidic aqueous solution[36] ........... 17

Table 2.5 Summary of $\mathrm{Mn}$ separation from $\mathrm{Co}$ and $\mathrm{Ni}$ and recovery from manganese

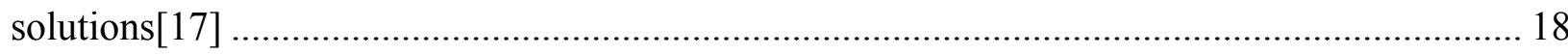

Table 2.6 Comparison of $\mathrm{pH} 50$ values for the extraction of various metals from sulphate

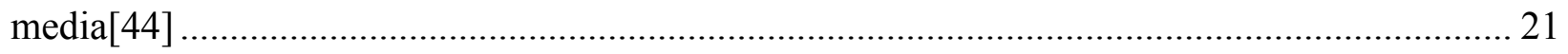

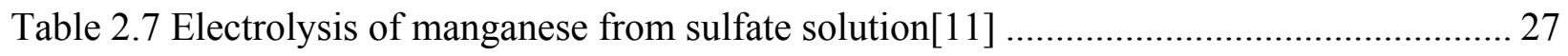

Table 2.8 the maximum admissible impurity content in industrial manganese electrolytes[60].. 30

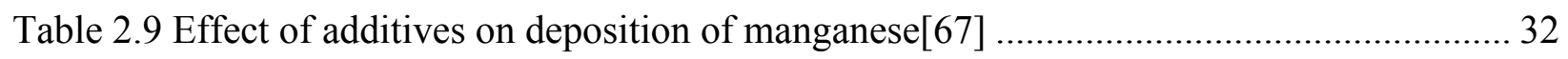

Table 2.10 Optimum conditions for manganese electrodeposition[3]

Table 2.11 Kinetics of $\gamma-\mathrm{Mn} \rightarrow \mathrm{a}-\mathrm{Mn}$ transition after electrolysis[70] .............................. 37

Table 3.1 Experimental conditions for the conductivity studies......................................... 44

Table 3.2 Measured conductivities of $\mathrm{MnCl}_{2}-\mathrm{NH}_{4} \mathrm{Cl}$ solutions at different temperatures .......... 44 
Table 3.3 Experimental conditions for the viscosity studies

Table 3.4 Measured viscosities of $\mathrm{MnCl}_{2}-\mathrm{NH}_{4} \mathrm{Cl}$ solutions at different temperatures

Table 4.1 Properties of commercial chelating resins 56

Table 4.2 Selected standard reduction potentials in aqueous solutions at $25^{\circ} \mathrm{C}[10]$ 61

Table 4.3 Cementation conditions 62

Table 4.4 Experimental conditions for the $\mathrm{pH}$ effect studies 68

Table 4.5 Removal rates of metals with various resins, \% 68

Table 4.6 Experimental conditions for the resin dosage effect studies. 69

Table 4.7 Experimental conditions for the resin quantities effect column studies 75

Table 5.1 Experimental conditions for the effect of impurities 89

Table 5.2 Experimental data for impurities use 90

Table 5.3 Experimental conditions for the effect of operation conditions 95

Table 5.4 Experimental data for optimizing operation conditions 96 


\section{List of Figures}

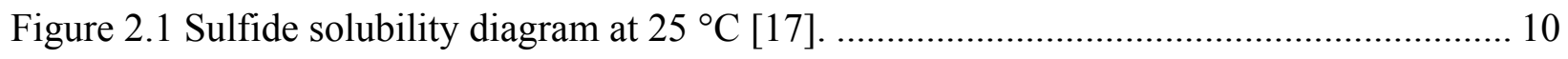

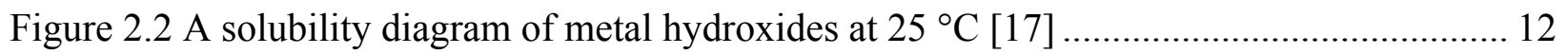

Figure 2.3 Sorption of certain metals on a chelating resin whose functional group is

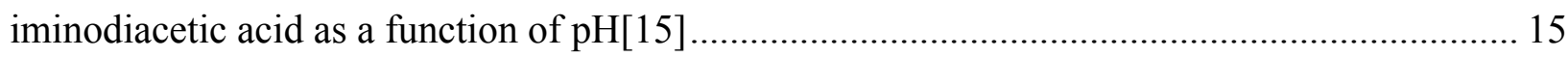

Figure 2.4 Extraction of Metals by CYANEX 272 Extractant from Sulfate Solutions[45] ......... 21

Figure 2.5 Extraction of Metals by CYANEX 272 Extractant from Chloride Solutions[45]....... 22

Figure 2.6 The $\mathrm{Mn}-\mathrm{H}_{2} \mathrm{O}$ Eh-pH diagram at $25^{\circ} \mathrm{C}$ and $0.1 \mathrm{M} \mathrm{Mn}$ species[52] .......................... 25

Figure 2.7 Process for production of electrolytic manganese (EM)[53] .................................. 26

Figure 2.8 Flow sheet of the electrolytic manganese metal plant[51] ....................................... 34

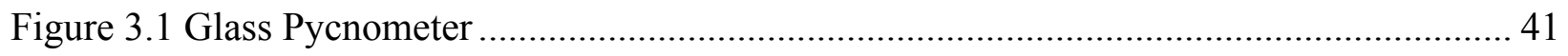

Figure 3.2 Densities of different concentrations of $\mathrm{MnCl}_{2}-\mathrm{NH}_{4} \mathrm{Cl}$ solutions at $25^{\circ} \mathrm{C}$.................. 42

Figure 3.3 Specific conductivities of $\mathrm{MnCl}_{2}-1.5 \mathrm{M} \mathrm{NH}_{4} \mathrm{Cl}$ solutions at different temperatures .. 45

Figure 3.4 Specific conductivities of $\mathrm{MnCl}_{2}-2.0 \mathrm{M} \mathrm{NH}_{4} \mathrm{Cl}$ solutions at different temperatures .. 45

Figure 3.5 Specific conductivities of $\mathrm{MnCl}_{2}-2.5 \mathrm{M} \mathrm{NH}_{4} \mathrm{Cl}$ solutions at different temperatures .. 46 
Figure 3.6 Arrhenius plots of viscosity of $\mathrm{MnCl}_{2}-1.5 \mathrm{M} \mathrm{NH} \mathrm{NH}_{4} \mathrm{Cl}$ solutions at different

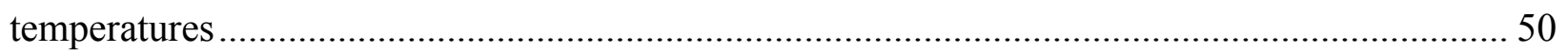

Figure 3.7 Arrhenius plots of viscosity of $\mathrm{MnCl}_{2}-2.0 \mathrm{M} \mathrm{NH} \mathrm{NH}_{4} \mathrm{Cl}$ solutions at different

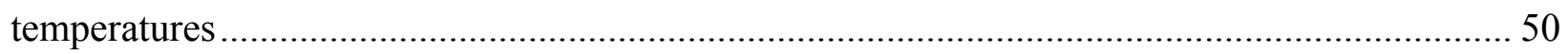

Figure 3.8 Arrhenius plots of viscosity of $\mathrm{MnCl}_{2}-2.5 \mathrm{M} \mathrm{NH} \mathrm{NH}_{4} \mathrm{Cl}$ solutions at different

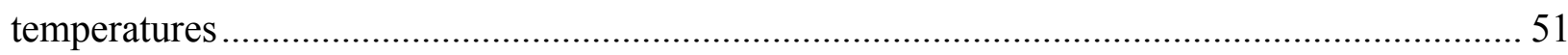

Figure 3.9 Comparison of calculated and tested values of viscosities ................................. 52

Figure 4.1 Potentiometric determinations of manganous ions with permanganate (blue = titration

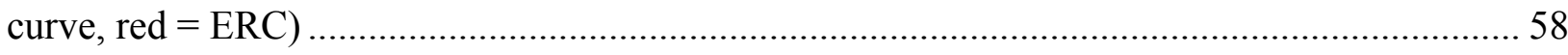

Figure 4.2 Experimental apparatus for cementation tests .............................................. 60

Figure 4.3 Schematic Diagram of Experimental Setup ....................................................... 61

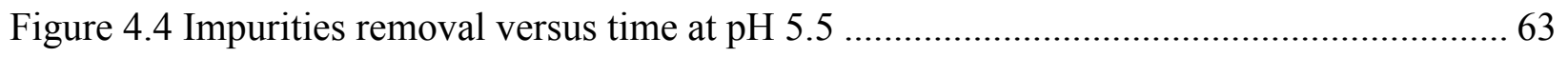

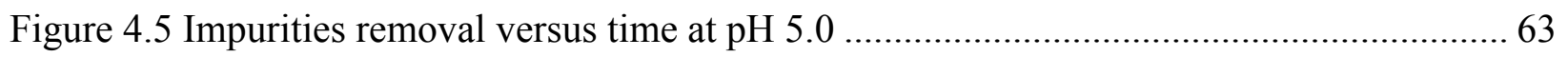

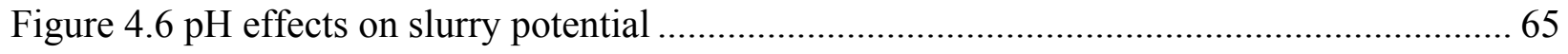

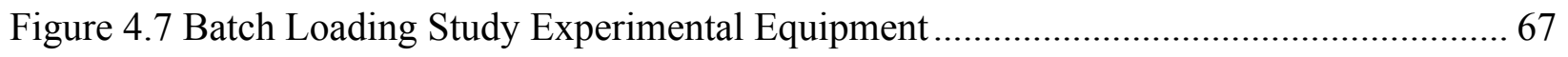

Figure 4.8 Effect of resin dosage on removal of impurities by Lewatit® MDS TP220 resin ( $p H 5$,

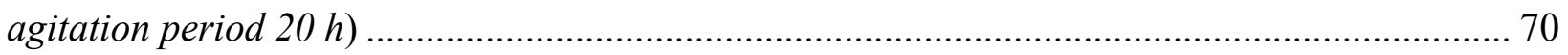


Figure 4.9 Effect of resin dosage on removal of impurities by Purolite S930Plus resin ( $p H 5$,

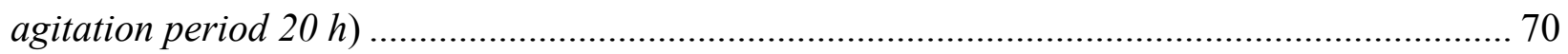

Figure 4.10 Lewatit ${ }^{\circledR}$ MDS TP220 resin dosage effect on the metal ions adsorption ( $p H 5$,

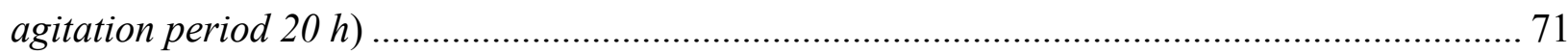

Figure 4.11 Purolite S930Plus resin dosage effect on the metal ions adsorption ( $p H$ 5, agitation

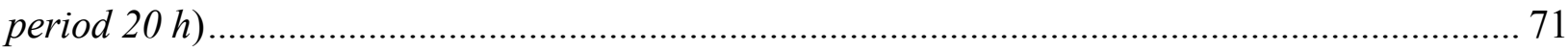

Figure 4.12 Column Loading Study Experimental Equipment ............................................ 74

Figure 4.13 Breakthrough curves of $\mathrm{Cu}^{2+}, \mathrm{Ni}^{2+}, \mathrm{Cd}^{2+}, \mathrm{Zn}^{2+}, \mathrm{Co}^{2+}$ and $\mathrm{Mn}^{2+}$ from a flow-through column test with manganese chloride solution by $3 \mathrm{~g}$ TP220 resin 76

Figure 4.14 Breakthrough curves of $\mathrm{Cu}^{2+}, \mathrm{Ni}^{2+}, \mathrm{Cd}^{2+}, \mathrm{Zn}^{2+}, \mathrm{Co}^{2+}$ and $\mathrm{Mn}^{2+}$ from a flow-through column test with manganese chloride solution by $3 \mathrm{~g}$ S930Plus resin 77

Figure 4.15 Breakthrough curves of $\mathrm{Cu}^{2+}, \mathrm{Ni}^{2+}, \mathrm{Cd}^{2+}, \mathrm{Zn}^{2+}, \mathrm{Co}^{2+}$ and $\mathrm{Mn}^{2+}$ from a flow-through column test with manganese chloride solution by $1 \mathrm{~g}$ TP220 resin. 78

Figure 5.1 Experimental apparatus for electrorefining tests ............................................. 86

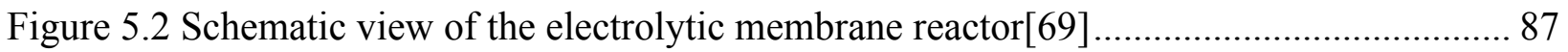

Figure 5.3 Effect of impurities on manganese electrorefining 90 
Figure 5.4 Manganese deposits produced from the solutions with different amount of impurities at $-10{ }^{\circ} \mathrm{C}, 500 \mathrm{~A} / \mathrm{m}^{2}, 24$ hours of deposition. 92

Figure 5.5 Scanning electron microscope (SEM) diagrams for sample a (Feed solution) 93

Figure 5.6 Scanning electron microscope (SEM) diagrams for sample e (Feed solution+200 ppb) 93

Figure 5.7 XRD diagram for sample a (Feed solution) 94

Figure 5.8 XRD diagram for sample e (Feed solution $+200 \mathrm{ppb})$ 94

Figure 5.9 Effect of current density on the current efficiency and specific energy consumption 97

Figure 5.10 Effect of cathode usage frequency on the current efficiency and specific energy consumption. 98

Figure 5.11 Manganese deposits produced from solutions with different operation conditions at $10{ }^{\circ} \mathrm{C}$ 100

Figure 5.12 Scanning electron microscope diagrams for sample g (Current density at $250 \mathrm{~A} / \mathrm{m}^{2}$, $48 \mathrm{~h})$ 101

Figure 5.13 Scanning electron microscope diagrams for sample h (Current density at $400 \mathrm{~A} / \mathrm{m}^{2}$, $30 \mathrm{~h})$ 101 
Figure 5.14 Scanning electron microscope diagrams for sample i (Current density at $500 \mathrm{~A} / \mathrm{m}^{2}$, $24 \mathrm{~h})$ 101

Figure 5.15 Scanning electron microscope diagrams for sample $\mathrm{j}$ (Current density at $750 \mathrm{~A} / \mathrm{m}^{2}$, $16 \mathrm{~h})$ 102

Figure 5.16 Scanning electron microscope diagrams for sample k (Current density at $1000 \mathrm{~A} / \mathrm{m}^{2}$, $12 \mathrm{~h})$ 102

Figure 5.17 Scanning electron microscope diagrams for sample 1 (Current density at $500 \mathrm{~A} / \mathrm{m}^{2}$, $48 \mathrm{~h})$ 102

Figure 5.18 Scanning electron microscope diagrams for sample m (Current density at $500 \mathrm{~A} / \mathrm{m}^{2}$, $24 \mathrm{~h}$, cathode $2^{\text {nd }}$ time use) 103

Figure 5.19 Scanning electron microscope diagrams for sample $\mathrm{n}$ (Current density at $500 \mathrm{~A} / \mathrm{m}^{2}$, $24 \mathrm{~h}$, cathode $3^{\text {rd }}$ time use) 103 


\section{List of Symbols}
$A_{c}$
Effective cathode area, in $\mathrm{m}^{2}$
C, Co
Initial and final concentrations, in $\mathrm{mg} / \mathrm{L}$
$d$
Density, in $\mathrm{g} \mathrm{cm}^{-3}$
$E_{M n}$
Electrochemical equivalent, in $\mathrm{g} /(\mathrm{A} \cdot \mathrm{h})$
$E_{\eta}$
Activation energy for viscous flow, in $\mathrm{KJ} / \mathrm{mol}$
$I_{c}$
Current density, in $\mathrm{A} / \mathrm{m}^{2}$
$k$
Conductivity, in $\mathrm{mS} / \mathrm{cm}$
$K_{s}$
Solubility constant
$m$
Mass, in $\mathrm{g}$
$M$
Molarity, in $\mathrm{mol} / \mathrm{L}$
$\frac{\Delta M c}{\Delta t}$
Weight gain of the cathode mass over $\Delta t$, in $\mathrm{g} / \mathrm{h}$
$\eta$
Viscosity, in cp
$\eta_{c}$
Cathode current efficiency, \% 
$p$

$Q_{e}$

$R$

$t$

$\Delta t$

V

$W_{M n}$
Purity, \%

Resin capacities, in $\mu \mathrm{g} / \mathrm{g}$

Gas constant, in $\mathrm{J} \cdot \mathrm{mol}^{-1} \cdot \mathrm{K}^{-1}$

Temperature, in ${ }^{\circ} \mathrm{C}$ or $\mathrm{K}$

Time interval, in $\mathrm{h}$

Volume, in L

Specific energy consumption, in $\mathrm{KWh} / \mathrm{t}$ 


\section{List of Abbreviations}

$\mathrm{AC}$

$\mathrm{ACE}$

BV

CCE

CNTs

CV

Cyanex 272

D2EHPA

EDTA

EM

EP

ERC

HDPE

ICP-MS
Activated carbon

Anodic current efficiency

Bed volume, in $\mathrm{ml}$

Cathodic Current Efficiency

Carbon nanotubes

Cell voltage, in $\mathrm{V}$

Bis-(2,4,4-trimethylpentyl) phosphinic acid

Di-(2-ethylhexyl) phosphoric acid

Ethylenediaminetetraacetic acid

Electrolytic manganese

End point of the titration

Endpoint Recognition Criterion

High-density polyethylene

Inductively Couple Plasma Mass Spectrometry 
ORP

PC88A

ppb

ppm

PVDF

RPM

SEM

SEC

SHE

$\mathrm{TBABr}$

$\mathrm{TEABr}$

$\mathrm{TPABr}$

ULSI

XRD
Oxidation-Reduction Potential

2-ethylhexyl phosphonic acid mono-2-ethylhexyl ester

parts per billion, $\mu \mathrm{g} / \mathrm{L}$

parts per million, $\mathrm{mg} / \mathrm{L}$

Polyvinylidene fluoride

Rotations per minutes

Scanning Electron Microscope

Specific Energy Consumption

Standard hydrogen electrode

Tetra butyl ammonium bromide

Tetra ethyl ammonium bromide

Tetra propyl ammonium bromide

Ultra large-scale integration

X-ray powder diffraction 


\section{Acknowledgements}

I would like to express my sincere gratitude to my supervisor, Dr. David Dreisinger, for his guidance, positive attitude and useful feedback throughout the entire course of my research work. It has been an honor to be one of his students.

I am highly grateful to Dr. Jianming Lu for his patient assistance and instruction with my experimental setup and answering my numerous questions. I also want to thank Dr. Bé Wassink for giving me invaluable suggestions during my research time.

I am deeply grateful to my fellow graduate students and staff in this department for their kind and patient support and help during this study.

In addition, thank you to Dr. Dreisinger, the department of Materials Engineering at UBC and 5N Plus and Mitacs Accelerate for providing the financial assistance necessary to undertaken this thesis.

Many thanks to my friends in Vancouver who have been always there for me. Thanks for your kindly advice and company. Hope everyone has a bright future.

Finally, I would like to thank my family for their understanding and encouragement throughout my studies. This would have been impossible without your support. 
Dedication

Ta be loved and love 


\section{Chapter 1: Introduction}

Manganese (Mn) is a naturally occurring element that is found in rock, soil and water. It is ubiquitous in the environment and comprises about $0.1 \%$ of the earth's crust. The most important source of manganese in the atmosphere results from the air erosion of dusts or soils[1]. Manganese does not exist in nature in the pure elemental state but instead combines with other elements in nearly 300 different minerals. Mn is extracted from several economically important oxide minerals including pyrolusite $\left(\mathrm{MnO}_{2}\right)$, psilomelane $\left(\mathrm{BaMn}_{9} \mathrm{O}_{16}(\mathrm{OH})_{4}\right)$, manganite $\left(\mathrm{Mn}_{2} \mathrm{O}_{3} \mathrm{H}_{2} \mathrm{O}\right)$, rhodochrosite $\left(\mathrm{MnCO}_{3}\right)$, and wad[2]. Manganese is an important industrial metal used as an additive for production of various steels, non-ferrous alloys, electronic components and specialty chemicals.

Either pyrometallurgical or hydrometallurgical processes can produce manganese. The typical manganese produced via pyrometallurgical routes is ferromanganese and silicomanganese. These products are not pure due to the presence of iron or silicon. Pure manganese metal is conventionally produced by hydrometallurgical processes (leaching, purification and electrowinning). Manganese electrodeposition from ammonium sulfate and chloride media has been well studied[3]. The most production of electrolytic manganese is from ammonium sulfate media due to some disadvantages of chloride media such as the removal of chlorine from the anolyte and consumption of ammonia at the anode[4]. However, sulfate media is not suitable for the production of high-purity manganese. The electrowinning process in the sulfate system requires sulfur dioxide gas $\left(\mathrm{SO}_{2}\right)$ or selenium compound addition to control the structure and morphology of manganese, increase the manganese quality, and stabilize the catholyte[5]. 
Accordingly, manganese produced from sulfate media contains sulfur $(0.002-0.1 \%)$ and selenium at levels that disqualify the product from use in high purity applications.

It is a promising way to produce the high-purity manganese by chloride media. It is reported that manganese can be electrorefined in halide media[6]. In such a situation, the impure manganese is the anode material, and then manganese is electrodeposited from a diaphragm cell (used to separate the cathode and anode to eliminate the contamination of the impurities from the anode). The anolyte solution in such a process will contain impurity elements and must be purified for small amounts of nickel, cobalt, copper, zinc, etc. before cathode deposition. There are many purification methods such as hydrolytic precipitation, sulfide precipitation, electrochemical methods, cementation, and ion exchange. The precipitation of metals in solutions as metal hydroxides is the most common way to remove metals from solutions in hydrometallurgical processes. But hydrolytic precipitation can only remove some impurities to some levels. It cannot be used for the level of purification required to achieve the high purity $\operatorname{Mn}[7]$. The precipitation and separation of metal sulfides from manganese is based on different sulfide solubilities of metals at a certain $\mathrm{pH}$ and temperature. Sulfide precipitation can effectively remove heavy metal impurities $(\mathrm{Ni}, \mathrm{Co}, \mathrm{Cu}$ et al.)[8]. However, sulfur from sulfides may be introduced to the manganese deposit if residual sulfide ion remains in the purified solution. Therefore cementation and ion exchange may be the most suitable technologies for this purification application. Manganese powder may be used to remove impurities by cementation as the manganese metal reduction potential is lower than all other metal reduction potentials $(\mathrm{Co}$, 
$\mathrm{Ni}, \mathrm{Cu}, \mathrm{Zn}$, etc.). Note that residual levels of contaminants must be in the range of less than 0.1 $\mathrm{mg} / \mathrm{L}$ to prevent contamination of the final manganese product to achieve $99.999 \%$ purity.

A fundamental study on electrorefining of high purity manganese in chloride media was performed. The objectives of this project are:

(1) To test the density, conductivity and viscosity of the different concentrations of $\mathrm{MnCl}_{2}$ $\mathrm{NH}_{4} \mathrm{Cl}$ solutions at different temperatures and find the high electrical conductivity and low viscosity solution for the following step.

(2) To investigate whether manganese powder could be used to remove the impurities from solutions at different $\mathrm{pH}$ values.

(3) To explore ion exchange removal of impurities by using equilibrium studies and column studies (Lewatit ${ }^{\circledR}$ MDS TP220 and Purolite S930Plus) and compare the performance of the two different resins.

(4) To explore the effects of the different concentrations of selected impurities added into the synthetic electrolyte feed solutions on the manganese refining process.

(5) To study the individual and synergistic effects of selected additives on the manganese electrorefining process and the quality of the manganese deposit.

(6) To optimize the operating parameters, including current density, electrolysis time and cathode usage frequency, in the manganese electrorefining process based on chloride media. 
In this thesis, previous studies on the manganese separation and recovery from solutions, and other background information are reviewed in Chapter 2. Chapter 3 describes the results of density, conductivity and viscosity of the different concentrations of $\mathrm{MnCl}_{2}-\mathrm{NH}_{4} \mathrm{Cl}$ solutions at different temperatures. The cementation study by manganese powder and the equilibrium studies and column studies of the Lewatit ${ }^{\circledR}$ MDS TP220 and Purolite S930Plus are presented in Chapter 4. Chapter 5 describes the results of electrorefining of manganese under different conditions. Finally, conclusions and recommendations of this research are presented in Chapter 6. 


\section{Chapter 2: Literature Review}

\subsection{Manganese Background}

\subsubsection{Physical Properties of Manganese}

Manganese is a gray-white metal that resembles iron. But it is harder and very brittle and its primary uses in a metallic form are as an alloying, de-sulfurizing, and deoxidizing agent for steel, cast iron, and nonferrous metals. Due to its high tendency to oxidize, annealing colors are often evident[9]. It is an important trace element and may be essential for utilization of vitamin B. Some basic information and classification of manganese are summarized in Table 2.1.

Table 2.1 Basic information and classifications of manganese[10], [11]

\begin{tabular}{llll}
\hline & Name: Manganese & $\bullet$ & Group in periodic table: 7 \\
- & Symbol: $\mathrm{Mn}$ & Melting point: $1519 \mathrm{~K}$ \\
- & Atomic number: 25 & Period in periodic table: 4 \\
- & Atomic weight: $54.938045(5)$ & B & Block in periodic table: d-block \\
& Standard state: solid at $298 \mathrm{~K}$ & Color: silvery metallic \\
& Boiling point: $2334 \mathrm{~K}$ & Classification: Metallic
\end{tabular}

Manganese belongs to group 7 and period 4 of the periodic table with an atomic number of 25 and atomic mass of 54.94. Six isotopes have been identified, of which only ${ }^{55} \mathrm{Mn}$ is stable. The other isotopes, ${ }^{51} \mathrm{Mn},{ }^{52} \mathrm{Mn},{ }^{54} \mathrm{Mn},{ }^{56} \mathrm{Mn}$, and ${ }^{57} \mathrm{Mn}$, have half-lives ranging from 46 min to $310 \mathrm{~d}$. Manganese exists in four allotropic forms: $\alpha, \beta, \gamma$, and $\delta$. 


\subsubsection{Chemical Properties of Manganese}

Manganese exhibits certain similar chemical properties to its neighbors in the periodic table, iron and chromium. The electronic configuration is $1 s^{2} 2 s^{2} p^{6} 3 s^{2} p^{6} d^{5} 4 s^{2}$.

Manganese has many oxidation states from -3 to +7 . But the most common oxidation states of manganese are $+2,+3,+4,+6$ and $+7 . \mathrm{Mn}^{2+}$ often competes with $\mathrm{Mg}^{2+}$ in biological systems. Manganese compounds in oxidation state +7 are restricted to the unstable oxide $\mathrm{Mn}_{2} \mathrm{O}_{7}$ and compounds of the intensely purple permanganate anion $\mathrm{MnO}_{4}{ }^{-}$. These two are powerful oxidizing agents. Compounds with oxidation states +5 (blue) and +6 (green) are strong oxidizing agents and are vulnerable to disproportionation[12]. The most stable oxidation state $(+2)$ for manganese has a pale pink color. There are many manganese (II) compounds, for example manganese (II) sulfate $\left(\mathrm{MnSO}_{4}\right)$, manganese (II) chloride $\left(\mathrm{MnCl}_{2}\right)$ and the mineral rhodochrosite (manganese (II) carbonate). Manganese dissolves in acids with liberation of hydrogen and formation of Mn (II) salts. Manganese metal dissolves readily in dilute sulphuric acid to form solutions containing the aquated $\mathrm{Mn}(\mathrm{II})$ ion together with hydrogen gas via the reaction below, and nitric acid dissolves manganese with evolution of hydrogen, nitrogen, and dinitrogen monoxide[11].

$$
\mathrm{Mn}(\mathrm{s})+\mathrm{H}_{2} \mathrm{SO}_{4}(\mathrm{aq})=\mathrm{Mn}^{2+}(\mathrm{aq})+\mathrm{SO}_{4}^{2-}(\mathrm{aq})+\mathrm{H}_{2}(\mathrm{~g})
$$

Reaction 2.1

\subsubsection{The Applications of Manganese}

Manganese plays an important part in industrial metallurgy and it is used as an additive for production of various steels, non-ferrous alloys, electronic components and special chemicals[4]. 
The rapidly growing demand for manganese has made it increasingly important to develop processes for economical recovery of manganese from low-grade manganese ores and other secondary sources. World manganese mine production was 17 million tonnes in 2013, an increase of 7.6\% compared with 15.8 million tonnes in 2012. South Africa was the largest producer in 2013, followed by China and Australia. The top three countries accounted for $41 \%$ of the total production in 2013. Other major producing countries include Gabon, Brazil, India, Kazakhstan, Ukraine, Malaysia, Mexico and Burma. Table 2.2 shows the mine production in 2011-2013. Manganese metal is essential to metallurgical industries, with major applications in production of steel and aluminum alloys. Manganese is often used by the steel industry in deoxidizing and desulfurizing additives and as an alloying constituent. Aluminum that contains $1.5 \%$ of manganese has an increased resistance against corrosion due to the formation of grains absorbing impurities, which would lead to galvanic corrosion[13]. Electrolytic manganese is a constituent of nonferrous metals as it improves strength, ductility, and hot-rolling properties in aluminum production[14]. Nonferrous applications of manganese include production of dry-cell batteries, plant fertilizer components, and colorant for bricks.

With the recent remarkable development of the advanced electronics industry, the higher-purity materials are increasingly required for the market. High-purity $\mathrm{Mn}$ is also essential as a raw material for CuMn alloys used as interconnection in Ultra Large-Scale integration (ULSI) for FeMn, PtMn, PtPdMn and GaMnAs alloys used as an optical isolator. Thus, the demand for high-purity Mn continues to grow rapidly[15]. 
Table 2.2 2011-2013 Mine production (Unit: thousand metric tons)[16]

\begin{tabular}{lccclccc}
\hline Country & $\mathbf{2 0 1 1}$ & $\mathbf{2 0 1 2}$ & $\mathbf{2 0 1 3}$ & Country & $\mathbf{2 0 1 1}$ & $\mathbf{2 0 1 2}$ & $\mathbf{2 0 1 3}$ \\
\hline Australia & 3200 & 3080 & 3100 & Kazakhstan & 390 & 380 & 390 \\
\hline Brazil & 1210 & 1330 & 1400 & Mexico & 171 & 188 & 200 \\
\hline China & 2800 & 2900 & 3100 & South Africa & 3400 & 3600 & 3800 \\
\hline Gabon & 1860 & 1650 & 2000 & Ukraine & 330 & 416 & 350 \\
\hline India & 895 & 800 & 850 & Malaysia & 225 & 429 & 250 \\
\hline Burma & 234 & 115 & 120 & Other countries & 1740 & 920 & 950 \\
\hline Total (rounded) & 16000 & 15800 & 17000 & & & & \\
\hline
\end{tabular}

\subsection{Previous Studies on Manganese Separation and Recovery from Solutions}

The increasing demand of manganese in recent years is driven by soaring growth of the world steelmaking industry. There has been great interest in manganese recovery from secondary manganese materials including Mn-bearing steel scraps, spent electrodes, waste electrolytes, spent catalysts, and from industrial mineral processing waste effluents[17]. The purity of the recovered manganese product is one of the most important factors to control the material properties and market uses. Since impurities at a low level influence the material properties, high purity materials are required to prepare well-controlled materials and devices[18]. The main methods for purification include sulfide precipitation, ion exchange, hydroxide precipitation, oxidative precipitation and solvent extraction. 


\subsubsection{Sulfide Precipitation of Metals from $\mathrm{Mn}^{2+}$ Solution}

Metal sulfide precipitation is an important process in hydrometallurgical treatment of ores and effluents to remove impurities[8]. The thermodynamic equilibria involved in metal sulfide precipitation by gaseous hydrogen sulfide $\left(\mathrm{H}_{2} \mathrm{~S}\right)$ can be expressed as:

$$
\begin{gathered}
\mathrm{H}_{2} \mathrm{~S}(\mathrm{~g})=2 \mathrm{H}^{+}+\mathrm{S}^{2-} \quad \mathrm{K}_{\mathrm{p}}=\left[\mathrm{H}^{+}\right]^{2}\left[\mathrm{~S}^{2-}\right] / \mathrm{P}_{\mathrm{H}_{2} \mathrm{~S}} \\
\mathrm{M}^{\mathrm{n}+}+\frac{n}{2} \mathrm{~S}^{2-}=\mathrm{MS}_{\mathrm{n} / 2} \quad \mathrm{~K}=\frac{1}{\left[\mathrm{M}^{\mathrm{n}+}\right]\left[\mathrm{S}^{2-}\right]^{\mathrm{n} / 2}}=\frac{1}{\mathrm{~K}_{\mathrm{s}}}
\end{gathered}
$$

Equation 2.1

Equation 2.2

Where $K_{s}$ is the solubility product of the metal sulfide. These relationships can be written in the forms:

$$
\begin{gathered}
\mathrm{pH}=-\frac{1}{2}\left(\log \mathrm{K}_{\mathrm{p}}-\log \mathrm{P}_{\mathrm{H}_{2} \mathrm{~S}}+\log \left[\mathrm{S}^{2-}\right]\right) \\
\log \left[\mathrm{M}^{\mathrm{n}+}\right]=\log \mathrm{K}_{\mathrm{S}}-\frac{\mathrm{n}}{2} \log \left[\mathrm{S}^{2-}\right]
\end{gathered}
$$

The concentration of sulfur species is a strong function of $\mathrm{pH}$. For a given $\mathrm{P}_{\mathrm{H}_{2} \mathrm{~S}}$, each can be plotted on a sulfide solubility diagram as shown in Figure 2.1. 


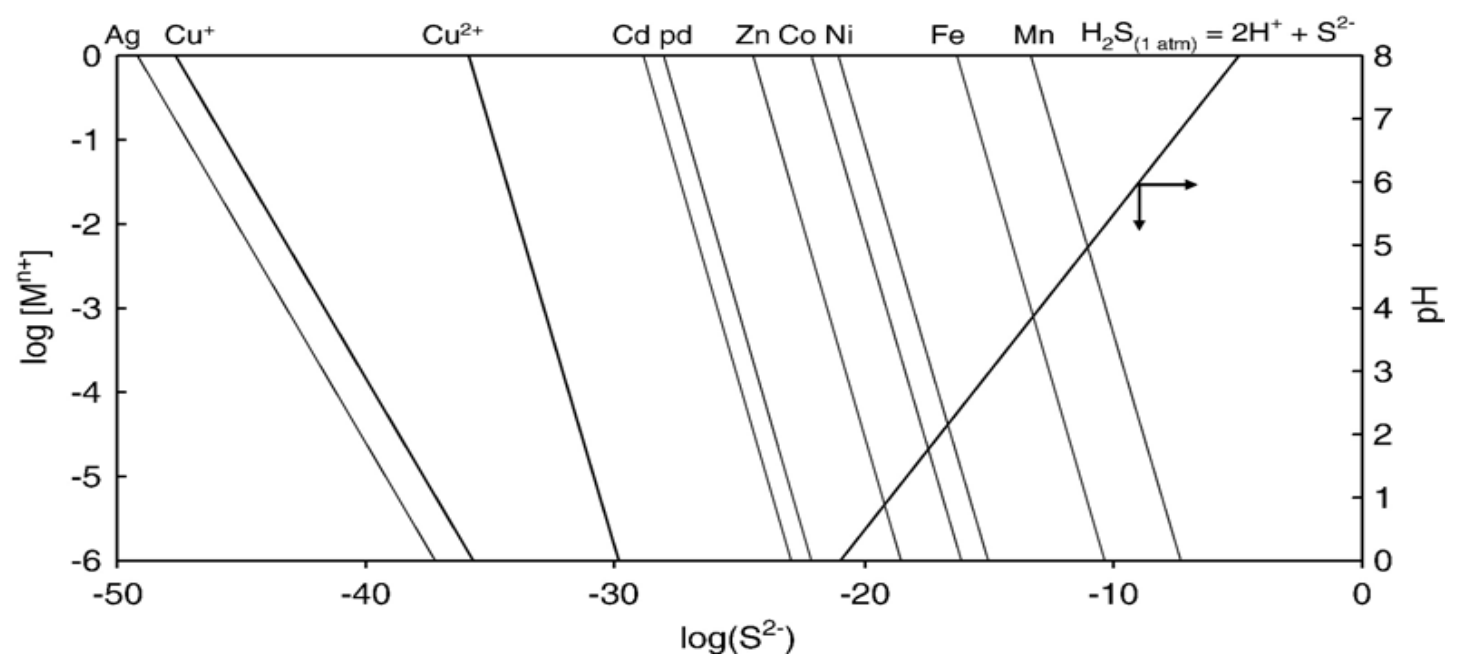

Figure 2.1 Sulfide solubility diagram at $25^{\circ} \mathrm{C}$ [17].

From the figure above, it is found that the line of $\mathrm{Mn}^{2+}$ is far to the right hand side of the diagram, indicating that manganese sulfide is more soluble than most other metal sulfides. Based on that, this provides a theoretical method for separation of $\mathrm{Mn}^{2+}$ from other metals such as $\mathrm{Cu}^{2+}$, $\mathrm{Zn}^{2+}, \mathrm{Co}^{2+}, \mathrm{Ni}^{2+}$, and $\mathrm{Fe}^{2+}$ in solution in hydrometallurgical processes, where other metal ions are precipitated as metal sulfides while $\mathrm{Mn}^{2+}$ ions remain in solution.

Jandova et al. examined a controlled sulfide precipitation process for the recovery of copper and nickel-cobalt concentrates from liquors originating from leaching manganese deep ocean nodules in $\mathrm{FeSO}_{4}-\mathrm{H}_{2} \mathrm{SO}_{4}-\mathrm{H}_{2} \mathrm{O}$ solutions. The metal ions studied included $\mathrm{Co}^{2+}, \mathrm{Cu}^{2+}, \mathrm{Fe}^{2+}, \mathrm{Ni}^{2+}$, $\mathrm{Mn}^{2+}$ and $\mathrm{Zn}^{2+}$. Promising results were obtained when copper and nickel-cobalt concentrates were precipitated with $5.5 \%$ solution of $\left(\mathrm{NH}_{4}\right)_{2} \mathrm{~S}[19]$.

Sulfide precipitation has some advantages, including the lower solubility of metal sulfide precipitates, potential for selective metal removal, fast reaction rates, better settling properties 
and potential for reuse of sulfide precipitates by smelting. However, sulfide precipitation is not used as widely as it could be because it is difficult to control the dosing of sulfide (due to the very low solubility of the metal sulfides and thus the sensitivity of the process to the dose) and because of concerns about the toxicity and corrosiveness of excess sulfide[20].

\subsubsection{Hydroxide Precipitation of Metals from $\mathrm{Mn}^{2+}$ Solution}

The hydroxide precipitation of metal hydroxides is considered as the most common method to remove metals from solutions in hydrometallurgical processes due to its relative simplicity, low cost and ease of $\mathrm{pH}$ control[7]. The metal hydroxides can be removed by flocculation and sedimentation. Metal precipitation is primarily dependent upon two factors: the concentration of the metal, and the $\mathrm{pH}$ of the solution. Table 2.3 shows a variety of hydroxide reagents that may be used to precipitate metals from the solution. The equilibria of metal hydroxide precipitation can be presented graphically in a solubility diagram Figure 2.2. From the figure below, it is found that by using the hydroxide precipitation it is easy to separate $\mathrm{Fe}^{3+}, \mathrm{Al}^{3+}$, $\mathrm{Pb}^{2+}$ and $\mathrm{Cu}^{2+}$ from $\mathrm{Mn}^{2+}$. But it is difficult to use this method to remove $\mathrm{Co}^{2+}, \mathrm{Ni}^{2+}$ from $\mathrm{Mn}^{2+}$. Generally, hydroxide precipitation in separation and/or recovery of manganese is only useful in some special cases in combination with other methods. 
Table 2.3 Heavy metal removals using chemical precipitation[21]

\begin{tabular}{|c|c|c|c|c|c|}
\hline Species & $\begin{array}{c}\text { Initial metal } \\
\text { conc. }\end{array}$ & Precipitant & Optimum $\mathrm{pH}$ & $\begin{array}{c}\text { Removal } \\
\text { efficiency (\%) }\end{array}$ & Ref. \\
\hline $\mathrm{Zn}^{2+}$ & $32 \mathrm{mg} / \mathrm{L}$ & $\mathrm{CaO}$ & $9-10$ & $99-99.3$ & $\begin{array}{c}\text { Ghosh et al., in } \\
\text { press }\end{array}$ \\
\hline $\begin{array}{c}\mathrm{Cu}^{2+}, \mathrm{Zn}^{2+}, \\
\mathrm{Cr}^{3+}, \mathrm{Pb}^{2+}\end{array}$ & $100 \mathrm{mg} / \mathrm{L}$ & $\mathrm{CaO}$ & $7-11$ & $99.37-99.6$ & Chen et al., 2009b \\
\hline $\mathrm{Cr}^{3+}$ & $5363 \mathrm{mg} / \mathrm{L}$ & $\mathrm{CaO}$ and $\mathrm{MgO}$ & 8 & $>99$ & Guo et al., 2006 \\
\hline
\end{tabular}

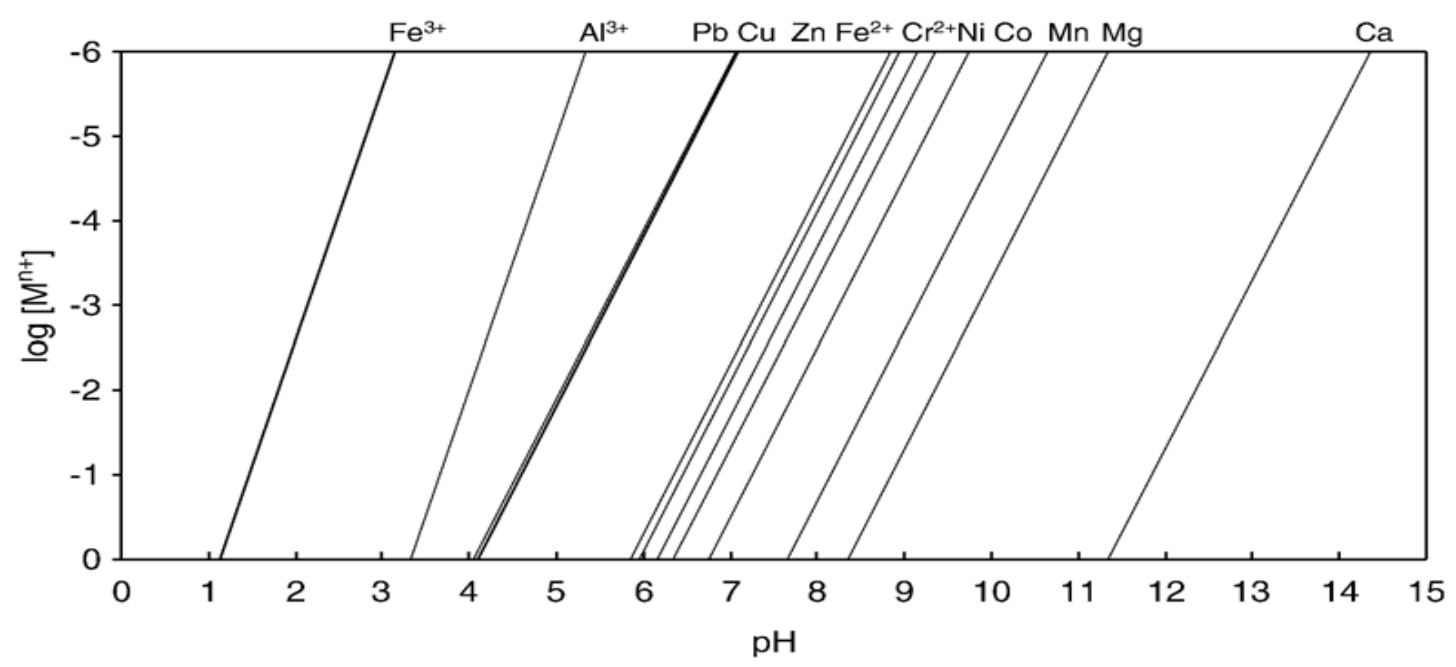

Figure 2.2 A solubility diagram of metal hydroxides at $25^{\circ} \mathrm{C}[17]$

Wensheng et al. found that only using hydroxide precipitation is not efficient to recover and remove manganese to very low levels because of its poor selectivity for manganese over magnesium at $\mathrm{pH}$ values above 8.5 to obtain $<100 \mathrm{mg} / \mathrm{L} \mathrm{Mn}$ and $\mathrm{pH}$ values above 9 for $<10 \mathrm{mg} / \mathrm{L} \mathrm{Mn}$. It was found manganese removal at these $\mathrm{pH}$ values resulted in substantial coprecipitation of magnesium[22]. Clark developed a novel way to separate and recover cobalt and manganese from spent bromide oxidation catalysts. Instead of hydroxide precipitation followed 
by selective leaching with ammonia, a selective precipitation of manganese with ammonia was used. Cobalt was recovered from a series of spent cobalt/manganese bromide oxidation catalysts containing $27-31 \% \mathrm{Co}, 25-33 \% \mathrm{Mn}, 0-14 \%$ Fe together with $\mathrm{Cr}, \mathrm{Cu}$ and $\mathrm{Ni}[23]$.

Although it is widely used, hydroxide precipitation also has some disadvantages. Firstly, hydroxide precipitation generates large volumes of relatively low-density sludge, which can present dewatering and disposal problems. Secondly, some metal hydroxides are amphoteric, and the mixed metals create a problem using hydroxide precipitation since the ideal $\mathrm{pH}$ for one metal may put another metal back into solution[24].

\subsubsection{Adsorption and Ion Exchange from $\mathrm{Mn}^{2+}$ Solution}

Adsorption is recognized as an effective and economic method for heavy metal removal. Adsorption process is considered better than other methods because of convenience, easy operation, simplicity of design and high-quality treated effluent. Further, this process can remove different types of pollutants and thus have wider applicability in water pollution control[25]. A fundamentally important characteristic of good adsorbents is their high porosity and consequent larger surface area with more specific adsorption sites[26].

Activated carbon (AC) adsorbents, carbon nanotubes (CNTs)[27] and bioadsorbents are used in the removal of heavy metal contaminants. Activated carbons display high adsorption capacity; but the price is so high that it has a major drawback for practical applications, especially in the field of industrial effluent treatment where activated carbons may play a very useful role. So it is very important to develop low cost and easily available adsorbents for the removal of heavy 
metal ions from the aqueous environment. Efforts have been made to develop low cost adsorbents for the removal of heavy metals from aqueous solutions[28]. However, there is still a need to find out the practical utility of such developed adsorbents on large-scale and safe and eco-friendly disposal of spent adsorbents[26].

Ion-exchange methods have been extensively used to remove heavy metals from the solution due to their many advantages, such as high treatment capacity, high removal efficiency and fast kinetics[29]. There are mainly two types of ion exchange resins, including cation exchange resin and anion exchange resin. Cation exchange resin, either synthetic or natural solid resin, has the specific ability to exchange cations with the metals in the solution. For anion exchange resins, in a hydrochloric acid media, many metallic ions form anion complexes with chloride ions as represented by Equation 2.5. Therefore, anion exchange resins may be used to separate metallic impurities from chloride solutions.

$$
\mathrm{M}^{\mathrm{n}+}+\mathrm{mCl}^{-}=\left[\mathrm{MCl}_{\mathrm{m}}\right]^{\mathrm{n}-\mathrm{m}}(\mathrm{n}-\mathrm{m}<0)
$$

Adsorption on chelating resins is one of the most convenient methods for the separation and recovery of metal ions. Especially, resins containing iminodiacetic acid groups are commercially available and widely used at both industrial and laboratory levels[30]. Masahito Uchikoshi used UNICELLEXÔ UR-30S for purification tests in $\mathrm{NH}_{4} \mathrm{Cl}$ media at various $\mathrm{pH}$ and flow rates, whose functional group is iminodiacetate[15]. Under the optimized conditions, $\mathrm{Co}, \mathrm{Cu}, \mathrm{Ni}$ and $\mathrm{Zn}$ were separated with chromatographic separation with the chelating resins, and $\mathrm{Al}, \mathrm{Cr}$ and $\mathrm{Fe}$ were separated by hydrolysis in the loading solution before separation. Figure 2.3 shows the 
concentration of metal ions absorbed on the chelating resin UNICELLEXÔ UR-30 from hydrochloric acid solution as a function of $\mathrm{pH}$.

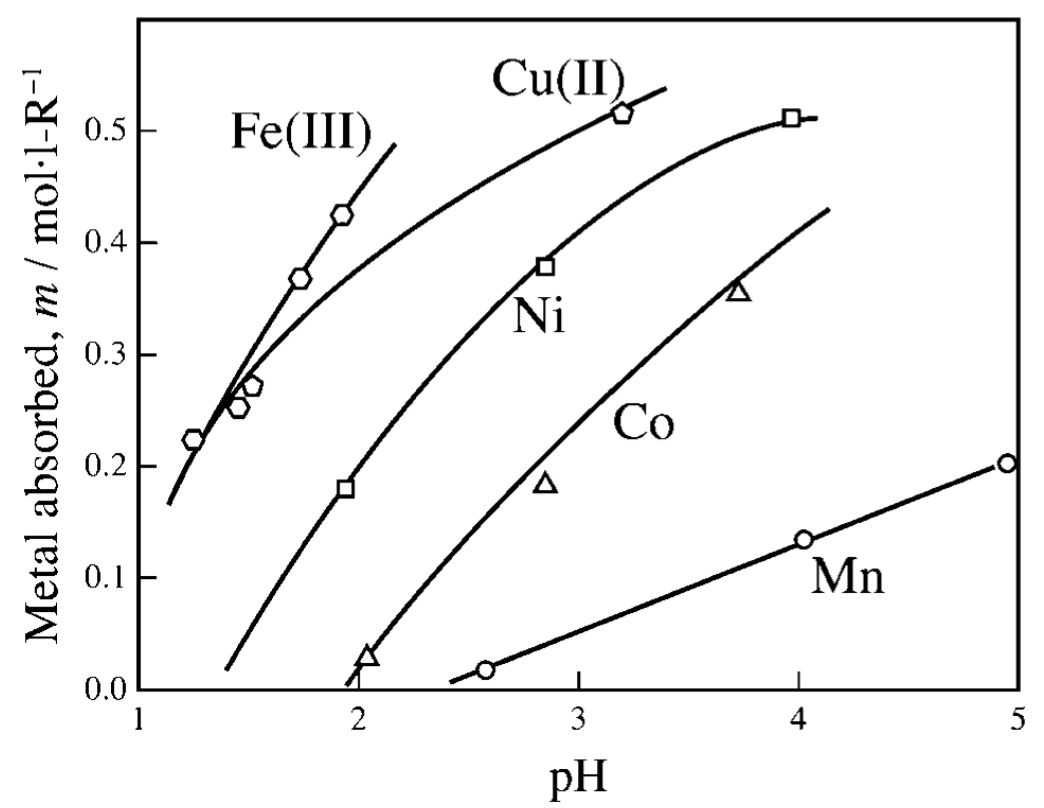

Figure 2.3 Sorption of certain metals on a chelating resin whose functional group is iminodiacetic acid as a function of $\mathrm{pH}[15]$

Diniz used Dowex M-4195, which is formerly marketed as Dow XFS 4195 and a macroporous resin, with a poly-styrene-divinylbenzene matrix, and a weakly basic chelating bispicolyl amine functional group for metal recovery from solution[31]. Heavy metals, such as copper, nickel, cobalt and lead, can be effectively and selectively removed from a highly acidic manganese chloride solution using the chelating resin Dowex M-4195, and the apparent sequence of affinity of metals is $\mathrm{Cu}>\mathrm{Ni}>\mathrm{Pb}>\mathrm{Fe}(\mathrm{III})>\mathrm{Co}>>\mathrm{Mn}$.

Mendes and Martins[32] investigated the sorption of nickel and cobalt by using the chelating resins Dowex M4195, Amberlite IRC748, Ionac SR-5, and Purolite S930 to separate the impurities from synthetic solutions simulating pressure acid leach liquors. It was found that all 
the above ion exchange resins are suitable for nickel and cobalt recovery from weakly acid solutions[33]. The resin may be used in ion exchange to either absorb the impurities or to recover the desired metal. Wolowicz found that Lewatit MonoPlus TP220 could entirely separate palladium(II), platinum(IV), gold(III) and copper(II) from acidic solution whereas zinc(II), nickel(II) and cobalt(II) were removed to a smaller extent. The resin shows negligible selectivity for palladium(II) ions compared to others. The series can be presented as follows: $\operatorname{Pd}(\mathrm{II})>$ $\mathrm{Au}(\mathrm{III})>\mathrm{Pt}(\mathrm{IV})>\mathrm{Cu}(\mathrm{II})>\mathrm{Zn}(\mathrm{II})>\mathrm{Co}(\mathrm{II})>\mathrm{Ni}(\mathrm{II})[34]$. Kuz'min carried out investigations of the efficiency of the sorption of copper and nickel, from the pulps deriving from the leaching of low-grade sulfide ores by hydrochlorination, using the chelating resin Purolite S930. At pH 2.73.0, copper, nickel, and cobalt recovery, for long resin contact times, exceeds $99 \%$ [35].

The resin selectivity observed in these synthetic industrial solution experiments agreed with the metal selectivity orders shown in Table 2.4. Additionally, these results illuminate the importance of considering useful resin operational capacity compared to total operational capacity - that is, the proportion of loading sites on the resin used to bind with the desired metal compared to undesirable metals[36]. 
Table 2.4 Resin metal loading selectivity orders in weakly acidic aqueous solution[36]

\begin{tabular}{llll}
\hline Resin & Functionality & Metal selectivity order & Reference \\
\hline Lewatit MonoPlus TP 207 XL & Iminodiacetic acid & $\mathrm{Fe}(\mathrm{III})>\mathrm{Cu}>\mathrm{Ni}>\mathrm{Al}>\mathrm{Co}>\mathrm{Mn}>\mathrm{Ca}>\mathrm{Mg}>\mathrm{K}>\mathrm{Na}$ & Current work \\
Lewatit MonoPlus TP 207 XL & Iminodiacetic acid & $\mathrm{Fe}(\mathrm{III})>\mathrm{Cu}>\mathrm{Ni}>\mathrm{Co}>\mathrm{Al}>\mathrm{Mn}>\mathrm{Ca}>\mathrm{Mg}>>\mathrm{Na}$ & Lanxess, 2011 \\
Amberlite IRC 748 & Iminodiacetic acid & $\mathrm{Fe}(\mathrm{III})>\mathrm{Cu}>\mathrm{Ni}>\mathrm{Co}>\mathrm{Mn}>\mathrm{Ca}>>\mathrm{Na}$ & Dow, 2001 \\
Lewatit MonoPlus TP 220 & Bis-picolylamine & $\mathrm{Cu}>\mathrm{Ni}>\mathrm{Fe}(\mathrm{III})>\mathrm{Co}>\mathrm{Mn}>>\mathrm{K}>\mathrm{Ca}>\mathrm{Na}>\mathrm{Mg}>\mathrm{Al}$ Current work \\
Dowex M4195 & Bis-picolylamine & $\mathrm{Cu}>>\mathrm{Ni}>\mathrm{Fe}(\mathrm{III})>\mathrm{Zn}>\mathrm{Co}>\mathrm{Cd}>\mathrm{Fe}$ (II) & Dow, 2006 \\
Dowex M4195 & Bis-picolylamine & $\mathrm{Cu}>\mathrm{Ni}>\mathrm{Fe}(\mathrm{III})>\mathrm{Co}>\mathrm{Mn}$ & Diniz et al., 2005 \\
AS & Acetic acid-sulfonic acid & $\mathrm{Fe}(\mathrm{III})>\mathrm{Cu}>\mathrm{Al}>\mathrm{Ni}>\mathrm{Mn}>\mathrm{Co}>\mathrm{Ca}>\mathrm{Mg}>\mathrm{K}>\mathrm{Na}$ & Current work \\
PS & Picolyl-sulfonic acid & $\mathrm{Cu}>\mathrm{Ni}>\mathrm{Fe}(\mathrm{III})>\mathrm{Co}>\mathrm{Al}>\mathrm{Ca}>\mathrm{Mn}>\mathrm{Mg}>\mathrm{K}>\mathrm{Na}$ & Current work \\
S & Sulfonic acid & $\mathrm{Fe}(\mathrm{III})>\mathrm{Al}>\mathrm{Ca}>\mathrm{Cu}>\mathrm{Ni}>\mathrm{Co}>\mathrm{Mn}>\mathrm{Mg}>\mathrm{K}>\mathrm{Na}$ & Current work \\
AP & Acetic acid-picolyl & $\mathrm{Cu}>\mathrm{Fe}(\mathrm{III})>\mathrm{Ni}>\mathrm{Co}>\mathrm{Al}>\mathrm{Mn}>\mathrm{Ca}>\mathrm{Mg}>\mathrm{K}>\mathrm{Na}$ & Current work \\
\hline
\end{tabular}

The resins with acetic acid functional groups (TP 207 XL, AP, AS) have a higher operational capacity but poorer selectivity for $\mathrm{Ni}$ and $\mathrm{Co}$ over $\mathrm{Fe}, \mathrm{Al}, \mathrm{Mn}, \mathrm{Mg}$, and $\mathrm{Ca}$. Alternatively, resins with picolyl functional groups (TP 220, AP, PS) offer improved selectivity of nickel and cobalt over other metals, but at the expense of operational capacity. For the sulfonic acid group (AS, PS, S), these resins presented low operational capacity for all metals tested under these conditions[36]. Chelating resins are of most interest for nickel and copper recovery. This class of resin has a high selectivity for copper at $\mathrm{pH}$ values above 2 and for nickel and cobalt over a $\mathrm{pH}$ range of $3-4$.

\subsubsection{Solvent Extraction from $\mathrm{Mn}^{2+}$ Solution}

In hydrometallurgical processing of manganese-containing materials, the leach liquors often contain ferrous, manganese, copper, nickel, cobalt and zinc along with other impurities. Solvent extraction is one of the most efficient methods used to remove, separate and concentrate metallic species from aqueous media and plays a vital role in purification and separation of manganese[2]. 
Di-(2-ethylhexyl) phosphoric acid (D2EHPA), 2-ethylhexyl phosphonic acid mono-2-ethylhexyl ester (PC88A) and bis-(2,4,4-trimethylpentyl) phosphinic acid (Cyanex 272) have been successfully used as extractants for various metal ions from sulfate solutions including zinc and manganese[37]. These three extractants for the separation of manganese from cobalt and nickel are summarised in Table 2.5.

Table 2.5 Summary of Mn separation from Co and Ni and recovery from manganese solutions[17]

\begin{tabular}{|c|c|c|}
\hline Extractant & Remark & Reference \\
\hline $\begin{array}{l}\text { D2EHPA-phosphoric } \\
\text { acid }\end{array}$ & $\begin{array}{l}\text { Mn removed for } \mathrm{Co} \mathrm{EW} \text { in the pilot } \mathrm{Mn} \mathrm{SX} \text { circuit } \\
\text { Continuous operation for separation of } \mathrm{Mn} \text { from Co at } \mathrm{pH} \\
4.2 \\
\text { Extn. order: } \mathrm{Zn} \sim \mathrm{Ca}>\mathrm{Mn}>\mathrm{Cu}>\mathrm{Co}>\mathrm{Ni}>\mathrm{Mg} \\
\text { Optimum pH } 3.5 \text { for } \mathrm{Mn} \text { from } \mathrm{Ni} \text { at } 40-60{ }^{\circ} \mathrm{C} \\
\text { Optimum } \mathrm{pH} 3 \text { for } \mathrm{Mn} \text { from } \mathrm{Co} \text { at } 23{ }^{\circ} \mathrm{C}\end{array}$ & $\begin{array}{l}\text { Dry et al. (1998) } \\
\text { Feather et al. (1999) } \\
\text { Hoh et al. }(1984) \\
\text { Cheng }(1999,2000)\end{array}$ \\
\hline PC 88A-phosphonic acid & $\begin{array}{l}\mathrm{Fe}(\mathrm{III})>\mathrm{Zn}>\mathrm{Pb}>\mathrm{Cu}>\mathrm{Mn}>\mathrm{Cd}>\mathrm{Ca}>\mathrm{Fe}(\mathrm{II})>\mathrm{Co}> \\
\mathrm{Mg}>\mathrm{Ni} \\
\mathrm{Mn} \text { over } \mathrm{Mg} \text { and } \mathrm{Ni}\end{array}$ & $\begin{array}{l}\text { Dreisinger and Cooper } \\
\text { (1984) }\end{array}$ \\
\hline $\begin{array}{l}\text { Cyanex 272-phosphinic } \\
\text { acid }\end{array}$ & $\begin{array}{l}\text { Bulong process: } \mathrm{Co}, \mathrm{Cu}, \mathrm{Zn} \text { and } \mathrm{Mn} \text { from } \mathrm{Ni}, \mathrm{Ca} \text { and } \mathrm{Mg} \\
\mathrm{Co} \text { and } \mathrm{Mn} \text { from } \mathrm{Ni} \text { at } \mathrm{pH} 6 \text { and } 50^{\circ} \mathrm{C} \\
\mathrm{Zn}>\mathrm{Cu}>\mathrm{Mn}>\mathrm{Co}>\mathrm{Mg}>\mathrm{Ca}>\mathrm{Ni} \\
\text { Separation of } \mathrm{Mn} \text { from } \mathrm{Ca} \text { and } \mathrm{Ni}\end{array}$ & $\begin{array}{l}\text { Taylor and Cairns (1997) } \\
\text { Hubicki and Hubicka } \\
\text { (1996) } \\
\text { Cole (2002) }\end{array}$ \\
\hline $\begin{array}{l}\text { D2EHPA } \\
\text { PC } 88 \text { A } \\
\text { Cyanex } 272\end{array}$ & $\begin{array}{l}\text { D2EHPA best with } \beta_{\mathrm{Mn} / \mathrm{Co}} \text { max at } \mathrm{pH} 4.45 \\
\text { D2EHPA }>\text { PC } 88 \mathrm{~A}>\text { Cyanex } 272\end{array}$ & Devi et al. (2000) \\
\hline
\end{tabular}

\subsubsection{D2EHPA-phosphoric Acid Extractant}

D2EHPA, di-2-ethylhexyl phosphoric acid, is by far the most widely used extractant for manganese[17]. D2EHPA pH-extraction isotherms from solutions each containing a single 
element showed that the extraction order for the seven elements of interest as a function of pH50 was $\mathrm{Zn}^{2+}>\mathrm{Ca}^{2+}>\mathrm{Mn}^{2+}>\mathrm{Cu}^{2+}>\mathrm{Co}^{2+}>\mathrm{Ni}^{2+}>\mathrm{Mg}^{2+}$. This confirmed that manganese would be extracted from sulfate solution ahead of cobalt and nickel. Extraction isotherms from solutions containing $\mathrm{Zn}, \mathrm{Ca}, \mathrm{Mn}, \mathrm{Cu}, \mathrm{Co}, \mathrm{Ni}$ and $\mathrm{Mg}$ showed that the separation of zinc and calcium from the other elements was not difficult and the separation of copper and manganese from cobalt and nickel was possible[38].

Biswas et al. investigated the kinetics of both forward and backward extractions of manganese with D2EHPA in the chloride medium by using a single drop technique. It was found that the rate of forward extraction of the investigated system is independent of the effective height of the column. The process is under mixed chemical and diffusion control under the condition of 0.04 $0.50 \mathrm{~mol} / \mathrm{L}$ D2EHPA and $\mathrm{pH}$ 1.0-3.0. The activation energy depends on the back-extraction parameters and is of the order of $20-40 \mathrm{~kJ} / \mathrm{mol}[39]$. Long et al. studied the extraction of zinc from sulfate solution using $20 \%$ saponified D2EHPA as an extractant and 260\# sulfonate kerosene as a diluent. Leaching solution of zinc ore was made up of $18,700 \mathrm{mg} / \mathrm{L}$ of $\mathrm{Zn}$ and 30 $\mathrm{mg} / \mathrm{L}$ of ferric ions. The extraction of $\mathrm{Zn}$ increased with increasing $\mathrm{pH}$, volume fraction of D2EHPA and O/A ratio. In a single stage under the condition of equilibrium $\mathrm{pH}$ of 2, $20 \%$ D2EHPA, O/A ratio of 1, 8 min of contact, $200 \mathrm{rpm}$ and settling time of $10 \mathrm{~min}$, the extraction yield of $\mathrm{Zn}$ was $\sim 38 \%$. Under the same conditions the extraction yield was $75 \%$ using saponified D2EHPA. Zn was stripped from ferric ions using $196 \mathrm{~g} / \mathrm{L}$ of $\mathrm{H}_{2} \mathrm{SO}_{4}$ and $88.60 \%$ zinc ion and $1.76 \%$ ferric ion were recovered[40]. Cheng $(1999,2000)$ used D2EHPA to remove copper and manganese from cobalt and nickel in synthetic nickel laterite leach solution. The separation of 
manganese from solutions containing cobalt and nickel by D2EHPA in kerosene was affected by temperature and $\mathrm{pH}$. At $\mathrm{pH} 3.0$, better separation of manganese from cobalt and nickel was achieved at room temperature. At $\mathrm{pH} 3.5$, better separation of manganese from cobalt was achieved at room temperature, while better separation of manganese from nickel could be obtained at elevated temperatures $40-60^{\circ} \mathrm{C}[38]$.

\subsubsection{Cyanex 272 Acid Extractant}

The active component of Cyanex 272 extractant is bis(2,4,4-trimethylpentyl)phosphinic acid and has been extensively proved to selectively extract cobalt from nickel[41]. Solvent extraction of divalent zinc and manganese from sulfate solutions was carried out using the sodium salt of Cyanex 272 by Devi et al[42]. The authors observed that the percentage of extraction of metal ions increased with increasing equilibrium $\mathrm{pH}$ and linearly with increasing extractant concentration up to $0.05 \mathrm{M}$. Salgado used a hydrometallurgical route based on the liquid-liquid extraction technique using Cyanex 272 as extractant and investigated the selective separation of metal values, in particular, zinc and manganese from spent alkaline batteries[43]. Cole investigated the extraction of metals from a sulfate medium with Cyanex 272 in toluene. The $\mathrm{pH} 50$ values for the extraction of various metal cations from sulfate media by Cyanex 272 are compared in Table 2.6 and Figure 2.4. From Table 2.6 and Figure 2.4, it is found that Cyanex 272 is a good extractant in terms of separation of cobalt from nickel, zinc from manganese, and manganese from nickel[44]. 
Table 2.6 Comparison of pH50 values for the extraction of various metals from sulphate media[44]

\begin{tabular}{|c|c|}
\hline Metal & $\mathrm{pH} 50$ \\
\hline $\mathrm{Zn}$ & 2.51 \\
\hline $\mathrm{Cu}$ & 4.13 \\
\hline $\mathrm{Mn}$ & 4.6 \\
\hline $\mathrm{Co}$ & 4.65 \\
\hline $\mathrm{Mg}$ & 5.59 \\
\hline $\mathrm{Ca}$ & 6.15 \\
\hline $\mathrm{Ni}$ & 6.58 \\
\hline
\end{tabular}

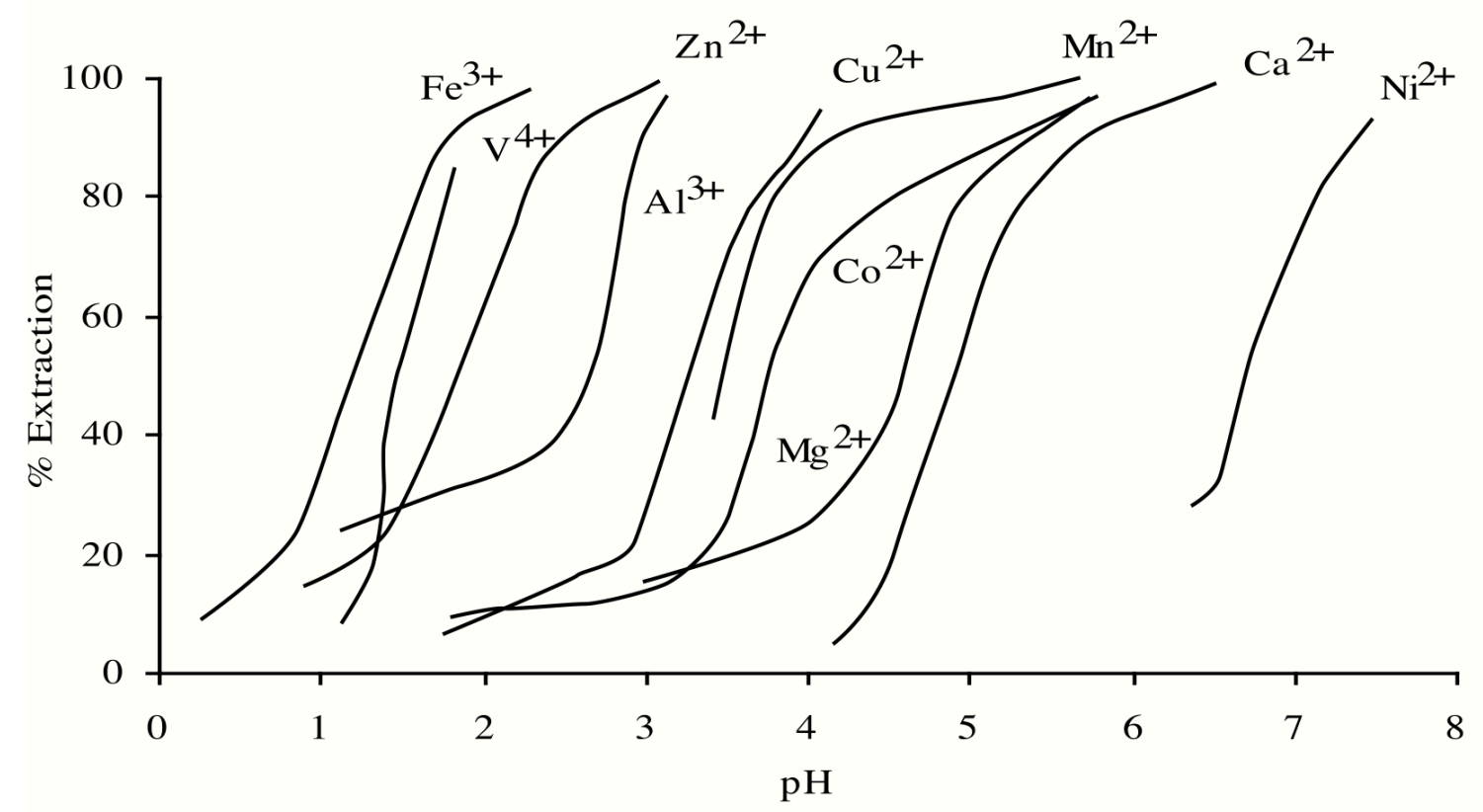

Figure 2.4 Extraction of Metals by CYANEX 272 Extractant from Sulfate Solutions[45] 


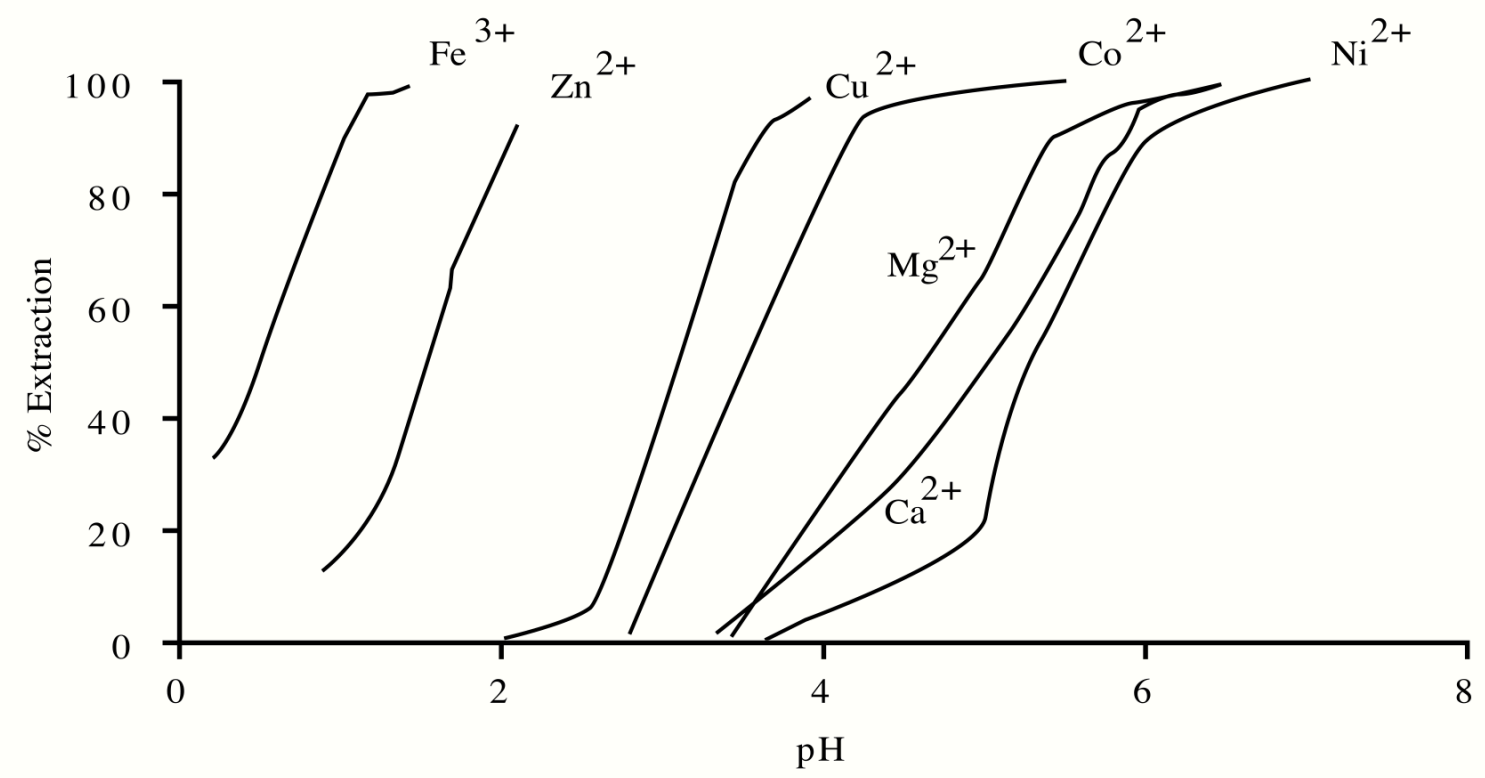

Figure 2.5 Extraction of Metals by CYANEX 272 Extractant from Chloride Solutions[45]

Cyanex 272 is a good extractant in terms of separation of cobalt from nickel, zinc from cobalt, and zinc from nickel (Figure 2.5).

\subsubsection{PC-88A Acid Extractant}

Compared to D2EHPA, PC88A is preferred for separating rare earth elements due to its high separation factor and high loading capacity[46], [47]. Thakur studied the extraction characteristics of the base metals $\mathrm{Mn}, \mathrm{Cu}, \mathrm{Co}$ and $\mathrm{Ni}$ by using the extractant 2-ethylhexyl phosphonic acid ( $\mathrm{PC}$ 88A). The extraction order of these metals has been established as $\mathrm{Mn}>\mathrm{Cu}>\mathrm{Co}>\mathrm{Ni}$ when the loading of the metal in the organic phase is low. On high loading the extraction order is $\mathrm{Cu}>\mathrm{Mn}>\mathrm{Co}>\mathrm{Ni}[48]$. Reddy et al. described a process to obtain a concentrated nickel sulfate solution from a nickel-containing cobalt raffinate using PC-88A as the extractant. 
More than $99 \%$ of nickel was extracted in three stages with $1 \mathrm{M}$ of extractant neutralized to $50 \%$ at $\mathrm{O} / \mathrm{A}$ ratio (organic phase volume/aqueous phase volume) of 2.2. Ni was stripped in two steps at the $\mathrm{O} / \mathrm{A}$ ratio of 5 with $\mathrm{H}_{2} \mathrm{SO}_{4}$ [49]. Dreisinger and Cooper used 2-ethylhexyl phosphonic acid mono-2-ethylhexyl ester (PC88A) in both sulfate and chloride media to study the effect of $\mathrm{pH}$, cobalt loading of the organic, temperature and extractant concentration on the cobalt--nickel separation $[50]$.

\subsection{Previous Studies on Manganese Recovery from Solution}

The standard reduction potential for $\mathrm{Mn}^{2+} / \mathrm{Mn}$ is $-1.18 \mathrm{~V}$ vs. SHE. Manganese is the least noble metal that can be electrodeposited from aqueous solutions on a commercial scale. Manganese electrodeposition from sulfate and chloride media has been most well studied[3]. The most production of electrolytic manganese is from sulfate media due to some disadvantages of chloride media such as the removal of chlorine from the anolyte and consumption of ammonia when ammonium chloride is present in the solution[5], [51].

Manganese electrowinning has to be conducted in a diaphragm cell so that the catholyte condition such as $\mathrm{pH}$ can be well controlled to maximize the manganese cathodic current efficiency and quality. Sulfur dioxide $\left(\mathrm{SO}_{2}\right)$ or selenium compounds are often used to control the structure and morphology of manganese, increase the manganese quality, and stabilize the catholyte. One major impurity of manganese metal deposited from sulfate media is sulfur (0.002$0.1 \%$ ). The amount of sulfur in electrolytic manganese depends on the concentration of $\mathrm{SO}_{2}$ in the plating solution. Therefore, sulfate media is not suitable for the production of high-purity manganese. It is promising to produce high-purity manganese by electrodeposition from halide 
media. Chloride systems have several advantages such as a lower energy consumption resulting from a lower cell voltage and a higher current efficiency, the ability to operate at a higher current density and the higher solubility of metals in the process solutions. As manganese is a very active metal and its self-dissolution may be too fast, it may not be suitable for conventional electrorefining like copper electrorefining. In such a situation, impure manganese should be first dissolved in chloride solution, and then manganese is electrodeposited from a diaphragm cell. If manganese self-dissolution is not significant, conventional electrorefining can be used to refine manganese. In this case, manganese is dissolved from an impure manganese anode and deposited on a cathode. In order to minimize the impurity contamination, a diaphragm cell still has to be used[4].

However, most of the previous studies were focused on the electrowinning of manganese. Little research on the electrorefining of manganese has been reported. Electrowinning of manganese is a major process for production of high purity electrolytic manganese (EM). The electrowinning systems can be classified based on the media such as sulfate and chloride because all the parameters differ substantially in different media.

\subsubsection{The Eh-pH Diagram for $\mathrm{Mn}-\mathrm{H}_{2} \mathrm{O}$ System}

The thermodynamics of electrochemical reduction of manganese (II) ions in aqueous solution can be discussed in terms of the Eh-pH diagram for the $\mathrm{Mn}-\mathrm{H}_{2} \mathrm{O}$ system. 


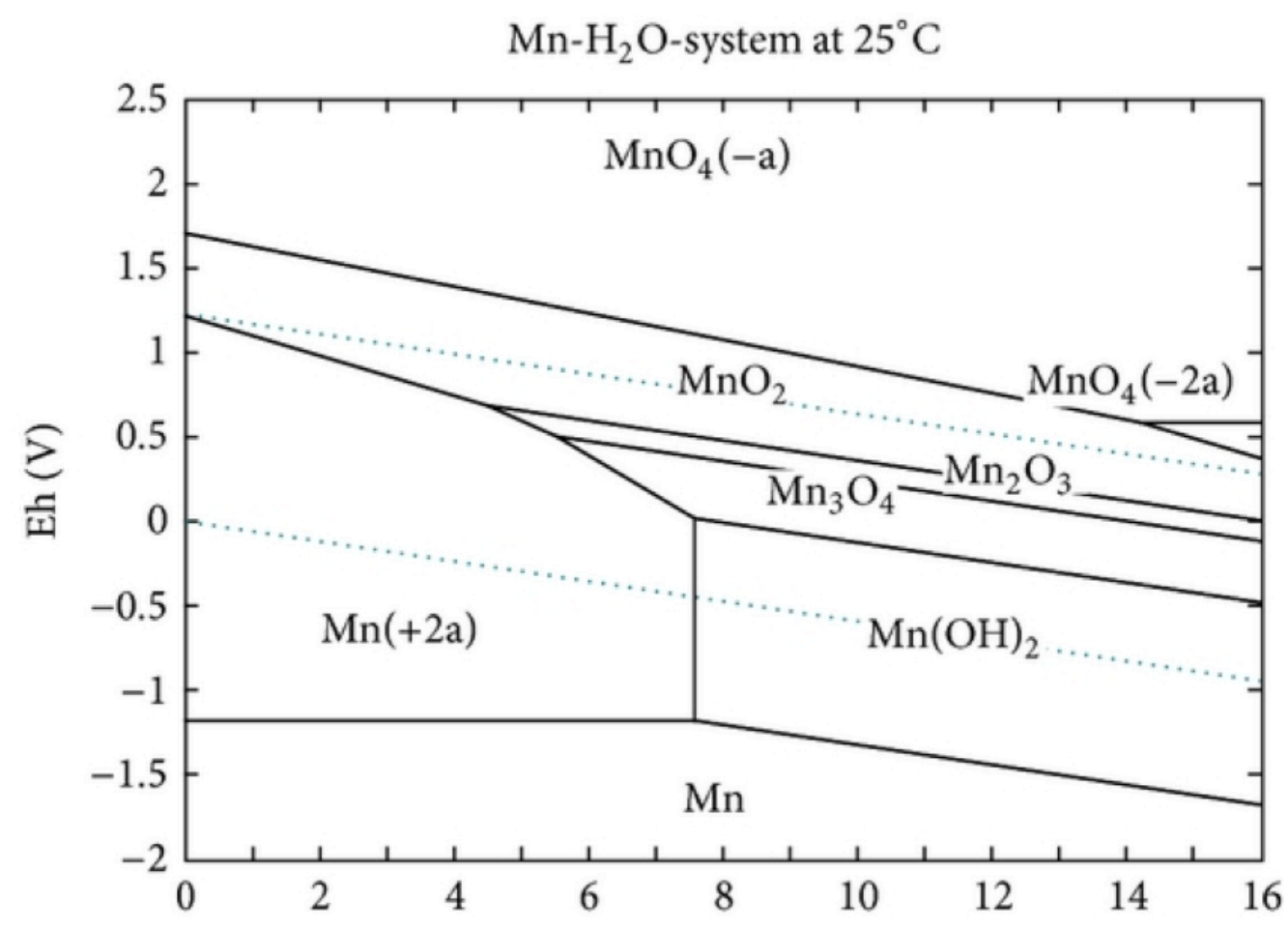

Figure 2.6 The $\mathrm{Mn}-\mathrm{H}_{2} \mathrm{O}$ Eh-pH diagram at $25^{\circ} \mathrm{C}$ and $0.1 \mathrm{M}$ Mn species[52]

Figure 2.6 indicates that in the aqueous solution, $\mathrm{Mn}$ (II) ions are only stable when the $\mathrm{pH}$ is below 8. Beyond that point, Mn (II) will convert to $\mathrm{Mn}(\mathrm{OH})_{2}$, which is precipitated in the solution. Under conditions of high redox potential, Mn (IV) is thermodynamically favourable and predominant in aqueous systems containing manganese. As the Eh decreases slightly, other compounds such as $\mathrm{Mn}_{2} \mathrm{O}_{3}$ and $\mathrm{Mn}_{3} \mathrm{O}_{4}$ can be also formed. However, all these phases might also develop even at lower Eh condition providing that the $\mathrm{pH}$ is raised as presented in the Figure 2.6[52]. It is evident from the diagram that at all $\mathrm{pH}$ where $\mathrm{Mn}^{2+}$ is dominant, the $\mathrm{Mn}^{2+} / \mathrm{Mn}$ couple lies far below the $\mathrm{H}^{+} / \mathrm{H}_{2}$ line, i.e. attempting to reduce $\mathrm{Mn}^{2+}$ in aqueous solution should produce hydrogen gas first; $\mathrm{H}^{+}$is a much stronger oxidant than $\mathrm{Mn}^{2+}$ at all relevant $\mathrm{pH}$. 
Nevertheless, $\mathrm{Mn}^{2+}$ electrowinning is practiced all over the world. It is another case of where kinetics apparently trumps thermodynamics. It turns out that on the surface of very pure manganese metal, overpotential for $\mathrm{H}^{+} / \mathrm{H}_{2}$ half reaction is high.

\subsubsection{Manganese Electrowinning from Sulfate Media}

Manganese metal is used in certain grades of steel, particularly in special steels such as the low carbon stainless steel grades, and in non-ferrous alloys in conjunction with aluminium and zinc. Most of world production of electrolytic manganese metal is produced by electrolysis of $\mathrm{MnSO}_{4}$ solutions. The overall process for production of electrolytic manganese from ores is made up of a series of steps as presented in Figure 2.7.

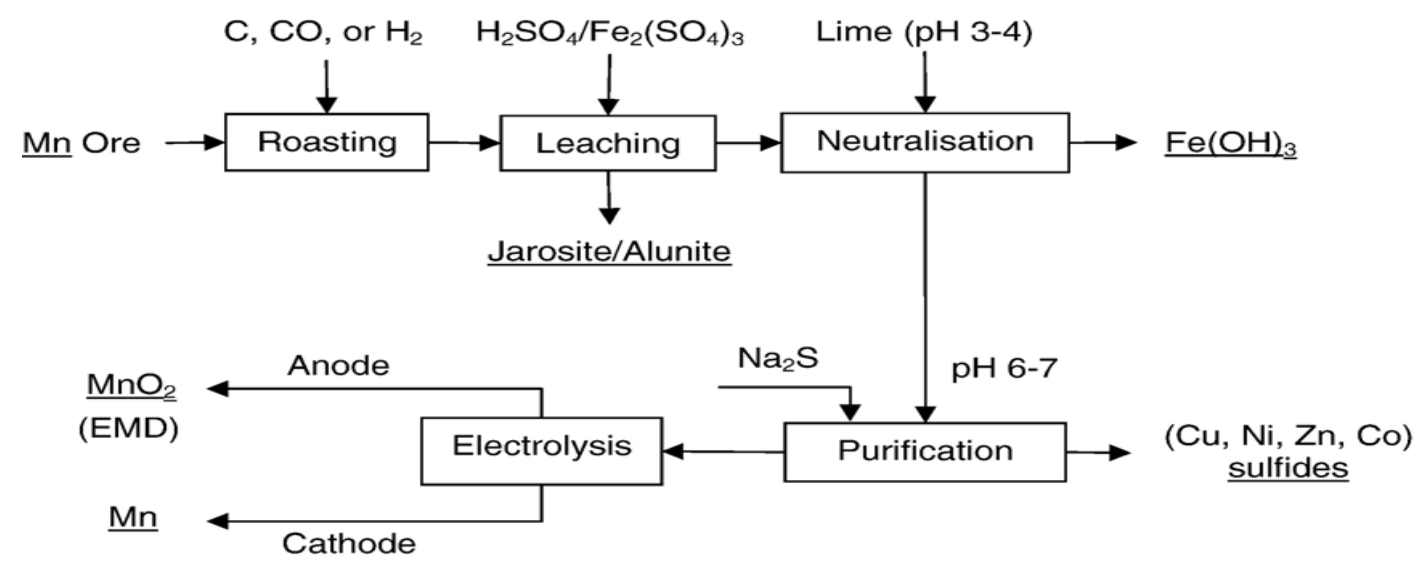

Figure 2.7 Process for production of electrolytic manganese (EM)[53]

From the figure, it is found that $\mathrm{Fe}^{3+}$ is typically removed by hydroxide precipitation at $\mathrm{pH} 3-4$ and other impurities such as $\mathrm{Ni}, \mathrm{Co}, \mathrm{Cu}, \mathrm{Zn}$ are removed by sulfide precipitation. The resultant $\mathrm{MnSO}_{4}$ solution after purification can be used for production of electrolytic manganese by 
electrowinning. The typical conditions required for the electrolysis process are summarised in Table 2.7.

Table 2.7 Electrolysis of manganese from sulfate solution[11]

\begin{tabular}{|c|c|}
\hline Condition & Value \\
\hline \multicolumn{2}{|l|}{ Feed solution, catholyte } \\
\hline $\mathrm{MnSO}_{4}$ & $30-40, \mathrm{~g} / \mathrm{L}$ \\
\hline$\left(\mathrm{NH}_{4}\right)_{2} \mathrm{SO}_{4}$ & $125-150, \mathrm{~g} / \mathrm{L}$ \\
\hline $\mathrm{SO}_{2}$ & $0.3-0.5, \mathrm{~g} / \mathrm{L}$ \\
\hline \multicolumn{2}{|l|}{ Anolyte } \\
\hline $\mathrm{MnSO}_{4}, \mathrm{~g} / \mathrm{L}$ & $10-20, \mathrm{~g} / \mathrm{L}$ \\
\hline $\mathrm{H}_{2} \mathrm{SO}_{4}, \mathrm{~g} / \mathrm{L}$ & $25-40, \mathrm{~g} / \mathrm{L}$ \\
\hline$\left(\mathrm{NH}_{4}\right)_{2} \mathrm{SO}_{4}, \mathrm{~g} / \mathrm{L}$ & $125-150, \mathrm{~g} / \mathrm{L}$ \\
\hline Current density, $\mathrm{mA} / \mathrm{cm}^{2}$ & $43-65$ \\
\hline Catholyte $\mathrm{pH}$ & $6-7.2$ \\
\hline Anode composition & $\mathrm{Pb}+1 \% \mathrm{Ag}$ \\
\hline Cathode composition & Stainless steel, type 316 \\
\hline Cell voltage & $5.1 \mathrm{~V}$ \\
\hline Temperature & $20^{\circ} \mathrm{C}$ \\
\hline Diaphragm & Acrylic \\
\hline Current efficiency & $60-70 \%$ \\
\hline
\end{tabular}


The predominant electrochemical reactions at the electrodes are as follows [54]:

Cathode:

$$
\begin{gathered}
\mathrm{Mn}^{2+}+2 \mathrm{e}^{-}=\mathrm{Mn} \\
2 \mathrm{H}_{2} \mathrm{O}+2 \mathrm{e}^{-}=\mathrm{H}_{2}+2 \mathrm{OH}^{-}
\end{gathered}
$$

Reaction 2.2

Reaction 2.3

At the diaphragm:

$$
\left(\mathrm{SO}_{4}\right)^{2-}+2 \mathrm{H}^{+}=\mathrm{H}_{2} \mathrm{SO}_{4}
$$

Reaction 2.4

Anode:

$$
\begin{gathered}
2 \mathrm{H}_{2} \mathrm{O}=4 \mathrm{H}^{+}+2 \mathrm{O}_{2}+4 \mathrm{e}^{-} \\
\mathrm{Mn}^{2+}+2 \mathrm{H}_{2} \mathrm{O}=\mathrm{MnO}_{2}+4 \mathrm{H}^{+}+2 e^{-}
\end{gathered}
$$

Reaction 2.6

A significant amount of manganese dioxide is precipitated at anodes and anode compartments can quickly be filled with anode sludge. Therefore the anode compartment should have enough extra space for anode sludge to allow a cell to operate for a sufficiently long time[4].

\subsubsection{Effect of Impurities}

From previous studies, it is found that it is difficult to obtain manganese deposit with uniform quality and high purity from readily available reagent grade chemicals at the laboratory scale. Manganese metal deposition is very sensitive to any amount of impurity. The current efficiency is affected by the amount of different metallic ions impurities and the evolution of hydrogen. The 
impurities having the more detrimental effect are $\mathrm{Fe}, \mathrm{Co}, \mathrm{Ni}, \mathrm{Sb}$, As and $\mathrm{Cu}$. It is believed that the deleterious impurities present lower hydrogen overpotential in basic medium, and contribute to high hydrogen gas release and low current efficiency of the process[55].

Mantell found that the impurities such as copper, cobalt, nickel and cadmium cause whatever manganese is plated on the cathode to recede from it, i.e. go back into solution. With the addition of the specified impurities even in trace amounts, the current density required for deposition is substantially increased and is accompanied by a slight increase in the voltage necessary for deposition[56]. But the addition of trace amounts of zinc to the catholyte actually enhances the deposition of manganese both in pure solutions and in solutions having trace amounts of the impurities usually accompanying the raw ore[57]. The presence of $\mathrm{Pb}$ in the furnace fines is also beneficial to the manganese metal deposition, increasing the current efficiency[58].

Zosimovich et al. pointed out that the impurities (e.g. $\mathrm{Cu}$, Co and $\mathrm{Ni}$ ) with low $\mathrm{H}_{2}$ overpotential co-deposit with manganese, resulting in a localized galvanic cell. The non-uniform distribution of current density on the cathode surface during electrodeposition resulted in the initiating galvanic cell. In the impurity-rich area, the $\mathrm{H}_{2}$ evolution is the dominant reaction, leading to an increase in $\mathrm{pH}$ and consequently a non-uniform distribution of $\mathrm{pH}$ on the surface. The presence of a galvanic pair causes an intense dissolution of the freshly deposited manganese, resulting in a low current efficiency and high energy consumption[59].

The maximum tolerable concentration of one impurity can be allowed to be higher if the other impurity concentrations are lower under the same conditions. The detrimental effects of impurities become more significant for longer manganese deposition time. Therefore the 
maximum tolerable concentration should be lower for a longer reaction time. Other operating conditions such as temperature, current density, $\mathrm{pH}$, solution composition, and additive dosages also affect the tolerance of impurities. Therefore, each manganese producer has its own standard for impurity limits. Typical impurity contents in the industrial electrolyte and their admissible concentrations are given in Table 2.8 .

Table 2.8 the maximum admissible impurity content in industrial manganese electrolytes[60]

\begin{tabular}{|c|c|c|}
\hline Elements & Maximum admissible (mg/L) & References \\
\hline $\mathrm{Al}$ & 1000 & \multirow[t]{4}{*}{ Ilea et al. 1997} \\
\hline $\mathrm{Co}$ & 0.5 & \\
\hline $\mathrm{Fe}$ & 10 & \\
\hline $\mathrm{Cu}$ & 5 & \\
\hline $\mathrm{Ni}$ & $0.1-1$ & O'Keefe 1984 \\
\hline \multirow[t]{2}{*}{$\mathrm{Zn}$} & 20 & Ilea et al. 1997 \\
\hline & $>5$ affect Mn quality & Mantell and Ferment 1969 \\
\hline Mo & 1.5 & Anon. 1949 \\
\hline
\end{tabular}

\subsubsection{Effect of Additives}

Dean reported that in all sulfate electrolytic manganese plants, sulfur dioxide is used as an additive to the catholyte. The effects generally attributed to the presence of a small amount of $\mathrm{SO}_{2}$ (typically 0.1-0.2 g/L) are[61], [62]: 
(1) Deposition of manganese in the brittle $\alpha$-phase rather than the ductile $\gamma$-phase

(2) Increase in $\mathrm{H}_{2}$ overpotential and current efficiency to around $60 \%$, independent of the nature of the cathode metal

(3) Change of crystal size and structure of the deposit to a fine and smooth surface

(4) Reduction of the deleterious effects of impurities

(5) Inhibition of oxidation of $\mathrm{Mn}^{2+}$ to $\mathrm{MnO}_{2}$ at the anode.

Yanitskii and his coworkers conducted a significant amount of work on the effect of selenium compounds on manganese electrodeposition and found that selenium is a more effective additive than $\mathrm{SO}_{2}$ especially with respect to current efficiency. Current efficiencies of 80 to $90 \%$ were easily achieved in electrowinning in sulfate media using the selenium additions[60], [63].

Although selenium compounds can effectively improve manganese electrodeposition, electrolytic manganese is contaminated with selenium. Selenium compounds in the electrolyte decompose to form colloid and precipitates, resulting in a high consumption of selenium and plugging of the diaphragm. These substances in the manganese deposits definitely decrease corrosion protection. Moreover, these additives are toxic and dangerous to the environment[64]. Besides selenium and sulfur compounds, many other additives especially organic compounds, such as carboxylic acids, water-soluble polyacrylamide, guar gum and thiourea, have been tested to improve manganese electrodeposition[65]. Subrat Kumar Padhy added the organic additives such as tetra ethyl ammonium bromide (TEABr), tetra propyl ammonium bromide (TPABr), and tetra butyl ammonium bromide (TBABr) to sulfate catholyte solutions to obtain the high quality manganese deposits. The concentrations of these additives were varied over a relatively broad 
range to evaluate their effect on current efficiency, specific energy consumption and deposit morphology of the electrodeposited manganese metal[66]. Table 2.9 summarizes the effect of additives on deposition of manganese.

Table 2.9 Effect of additives on deposition of manganese[67]

\begin{tabular}{|c|c|l|}
\hline Reagent & $\begin{array}{c}\text { Concentration of solution, } \\
\mathrm{mg} / \mathrm{L}\end{array}$ & \multicolumn{1}{|c|}{ Effect } \\
\hline Glue & $5-30$ & $\begin{array}{l}\text { Less than } 30 \mathrm{mg} \text {, no effect; greater } \\
\text { than } 30 \mathrm{mg} \text {, darkening of deposit }\end{array}$ \\
\hline Gelatin & Up to 50 & No effect \\
\hline Gum arabic & Up to 30 & Similar to glue \\
\hline Goulac & Up to 20 & Dark deposit at higher concentrations \\
\hline Ammonium citrate & Up to 1 & No effect \\
\hline $\begin{array}{c}\text { Surface active agents: } \\
\text { X-1, Duponol S, Dreft, } \\
\text { Tergitol, Penetrant 5, } \\
\text { etc. }\end{array}$ & $5-200$ & $\begin{array}{l}\text { No effect except froth at high } \\
\text { concentration }\end{array}$ \\
\hline
\end{tabular}

\subsubsection{Manganese Electrowinning from Chloride Media}

The sulfate media are not suitable for the production of high-purity manganese. One promising way for the production of high-purity manganese is electrodeposition from halide media. There are many potential advantages in producing electrolytic manganese metal by the electrolysis of $\mathrm{MnCl}_{2}$ solutions, such as[51], [58]:

(1) Lower energy consumptions results from lower cell potentials; 
(2) A greater manganese strip can be used, thereby decreasing the size of the solution preparation plant and the amount of pumping;

(3) Higher current densities can be used, thereby decreasing the size of the electrolysis plant.

However, the chloride system has some certain disadvantages, namely:

(1) Ammonia is destroyed at the anode in large amounts and must be replaced;

(2) The small amount of chlorine formed at the anode must be removed and destroyed.

(3) The solutions are more corrosive, requiring expensive materials of construction

Figure 2.8 shows a flow pattern of the electrolytic manganese plant. The predominant electrochemical reactions at the electrodes are as follows:

Cathode:

$$
\begin{gathered}
\mathrm{Mn}^{2+}+2 \mathrm{e}^{-}=\mathrm{Mn} \\
2 \mathrm{H}_{2} \mathrm{O}+2 \mathrm{e}^{-}=\mathrm{H}_{2}+2 \mathrm{OH}^{-}
\end{gathered}
$$

Reaction 2.3

Anode:

$$
\begin{gathered}
2 \mathrm{Cl}^{-}=\mathrm{Cl}_{2}+2 \mathrm{e}^{-} \\
3 \mathrm{Cl}_{2}+2 \mathrm{NH}_{3}=\mathrm{N}_{2}+6 \mathrm{HCl} \\
\mathrm{Mn}^{2+}+2 \mathrm{H}_{2} \mathrm{O}=\mathrm{MnO}_{2}+4 \mathrm{H}^{+}+2 e^{-}
\end{gathered}
$$

Reaction 2.8

Reaction 2.9 


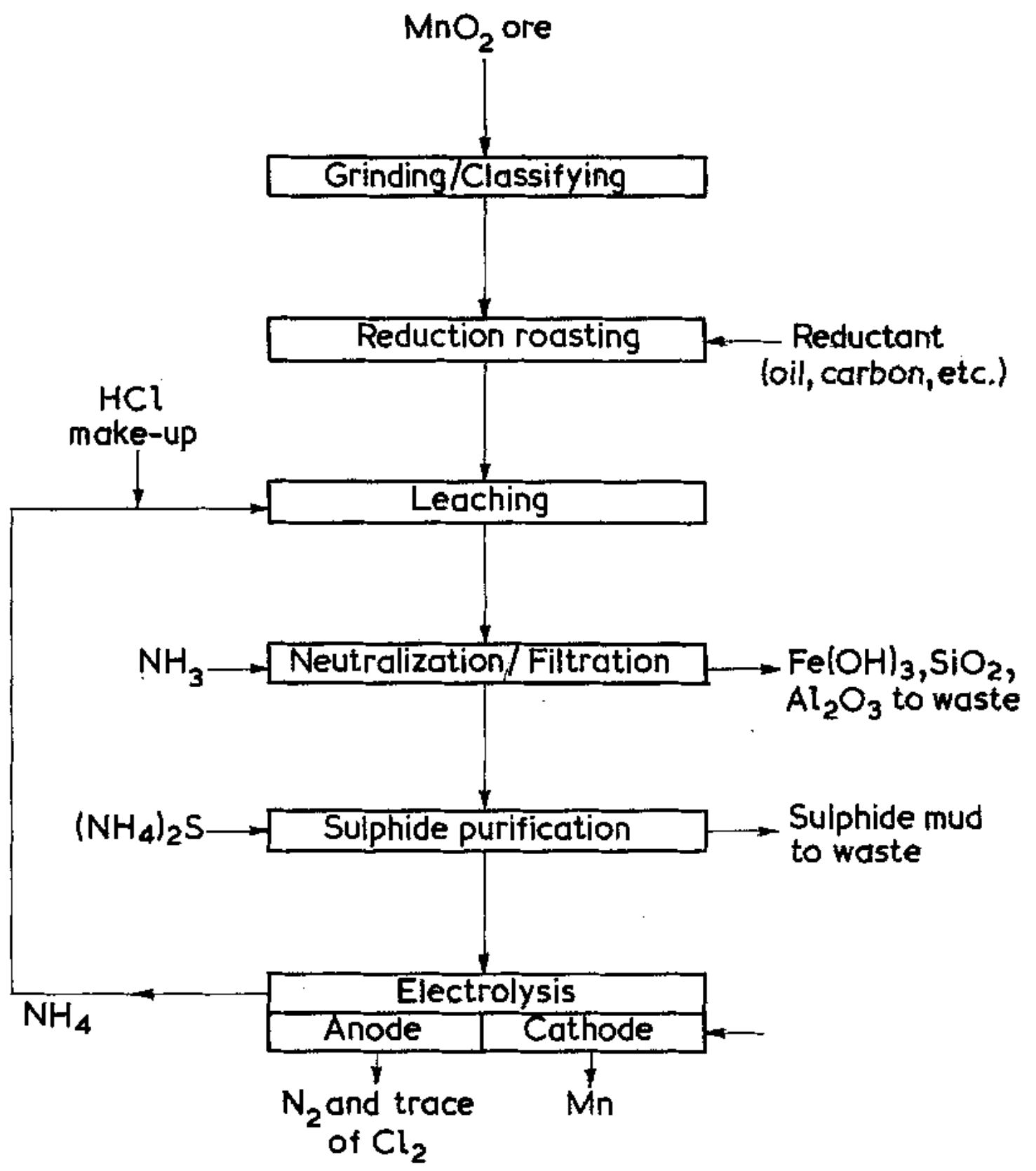

Figure 2.8 Flow sheet of the electrolytic manganese metal plant[51] 


\subsubsection{Deposition Conditions}

The temperature, solution composition, $\mathrm{pH}$ and current density have a great effect on the cathodic and anodic current efficiency and manganese deposit morphology. They are key operation parameters for successful manganese electrodeposition. The operation conditions vary for different manganese electrowinning process[51]. A lower temperature results in a higher cathodic current efficiency and better deposit quality. However if the operation temperature is too low, cooling electrolyte may not be affordable. Conventionally the temperature is always in the range of 25 to $40{ }^{\circ} \mathrm{C}$. S. Tajima found that adherent, compact and higher purity manganese was obtained by electrolysis in manganese chloride solutions at a lower temperature $\left(\sim-16^{\circ} \mathrm{C}\right)$ without any additives such as sulfur or selenium compounds. The optimum conditions for manganese electrodeposition are summarized in Table 2.10 .

Table 2.10 Optimum conditions for manganese electrodeposition[3]

\begin{tabular}{|l|c|}
\hline Anode & Graphite \\
\hline Cathode & Brass \\
\hline $\mathrm{NH}_{4}{ }^{+}$concentration & $2.0 \mathrm{~mol} / \mathrm{L}$ \\
\hline Catholyte $\mathrm{MnCl}_{2} \bullet 4 \mathrm{H}_{2} \mathrm{O}$ & $298 \mathrm{~g} / \mathrm{L}$ \\
\hline Diaphragm & No. 84 filter paper or vinylidene chloride canvas \\
\hline $\mathrm{pH}$ & $4.5 \sim 7.0$ \\
\hline Temperature & Below $-10^{\circ} \mathrm{C}$ \\
\hline Current density & $1-4 \mathrm{~A} / \mathrm{dm}^{2}$ \\
\hline Deposition time & 40 hours \\
\hline Current efficiency & $80 \%$ \\
\hline
\end{tabular}


The manganese chloride solubility is close to $10 \mathrm{M}$ at $20{ }^{\circ} \mathrm{C}$. Therefore a high manganese concentration can be used to maintain a high manganese deposition current efficiency[51]. However, manganese can be precipitated as manganese hydroxide at a high $\mathrm{pH}$ value. The hydrogen evolution during manganese electrodeposition results in a high surface $\mathrm{pH}$, then precipitation of manganese hydroxide on manganese deposit, and finally a low cathodic current efficiency and poor deposit quality. Therefore the manganese concentration should be reasonably high[68]. The main roles of ammonium chloride are $\mathrm{pH}$ buffering and complexation with $\mathrm{Mn}^{2+}$ to stabilize manganese and prevent its precipitation. Besides the addition of ammonium chloride increases the conductivity and then reduces the cell voltage and energy consumption[69]. The $\mathrm{pH}$ affects the cathodic and anodic process significantly. If $\mathrm{pH}$ is too high (over 7.0), $\mathrm{Mn}^{2+}$ is readily oxidized to $\mathrm{MnOOH}$ by air and also precipitated on manganese deposits. If $\mathrm{pH}$ is too low (less than 5), the manganese deposition efficiency decreases while the manganese anodic current efficiency increases. Jacobs et al. [5] found a much stronger dependence on $\mathrm{pH}$. In their experiments, a 7-10\% drop in current efficiency occurred with a change of $\mathrm{pH}$ from 7.4-7.0. J. E. Lewis[51] found that current efficiency was not particularly sensitive to $\mathrm{pH}$ in the range of $\mathrm{pH}$ 67.4. As a result, a pH of approximately 6 was used, as this was easily maintained. The current density affects the manganese cathodic and anodic current efficiencies, and deposit morphology and purity. Araujo et al.[58] and Jacobs et al.[67] found that the manganese current efficiency first increases with increasing current density, reaches a maximum value and then decreases when increasing current density. The current efficiency or relative rate of manganese to hydrogen evolution as a function of current density is related to the other operation conditions such as temperature and deposition time. With increasing deposition time, the manganese deposit 
gradually becomes rougher and more dendritic, resulting in an increase in the rate of manganese dissolution. Table 2.11 illustrates the transition $\gamma-\mathrm{Mn} \rightarrow \alpha-\mathrm{Mn}$ after $2 \mathrm{~h}$ of electrolytic deposition at room temperature. The authors of these articles have indicated that the duration of the transition of the plastic $\gamma$-Mn phase to the solid $\alpha$-Mn phase depends very much on the purity of the metal and thickness of the coating.

Table 2.11 Kinetics of $\boldsymbol{\gamma}$-Mn $\rightarrow \boldsymbol{\alpha}$-Mn transition after electrolysis[70]

\begin{tabular}{|l|l|}
\hline Time after electrolysis, $\mathrm{h}$ & Phase determined by XRD analysis \\
\hline $1-192$ & $\gamma+$ traces of $\alpha$ \\
\hline 216 & $\gamma+$ small amount of $\alpha$ \\
\hline 240 & $\gamma+$ bigger amounts of $\alpha$ \\
\hline 264 & $\gamma+$ fairly big amounts of $\alpha$ \\
\hline 288 & Equal amounts of $\gamma$ and $\alpha$ \\
\hline $336-360$ & $\gamma+$ constantly increasing amounts of $\alpha$ \\
\hline $360-456$ & Mainly $\alpha$, small amounts of $\gamma$ \\
\hline $450-528$ & Gradually decreasing amounts of $\gamma$. No $\gamma$ detected after $528 \mathrm{~h}$. \\
\hline
\end{tabular}

\subsubsection{Effect of Additives}

Lewis found that the use of selenium additives [either as $\mathrm{Se}(\mathrm{IV})$ or $\mathrm{Se}(\mathrm{VI})$ ] instead of sulfur dioxide in the electrowinning of manganese from chloride electrolytes increases the cathodic current efficiency by $15-20 \%$. The selenium level in the deposit increases with increasing selenium concentration in the catholyte but is lower when selenium is added as the selenate 
$[\mathrm{Se}(\mathrm{VI})]$ rather than as selenious acid [Se(IV)]. The valence of the selenium addition does not have a pronounced effect on either cathodic current efficiency or specific energy consumption. No dependence of selenium pick-up on the concentration of manganese and ammonium ions in the catholyte was observed[62]. 


\section{Chapter 3: Physical Properties of Manganese Electrorefining Electrolytes}

\subsection{Introduction}

Physical properties of electrolytes such as electrical conductivity, density and viscosity all have considerable economic importance in refining. Electrical conductivity is the measure of a material's ability to allow the transport of an electric charge. Viscosity is a quantitative measure of a fluid's resistance to flow and it is defined as the internal friction of a fluid. Conductivity is related to electrical energy consumption while density and viscosity may influence heat transfer and the carryover of impurity from the anode into the final cathode product[71], [72]. These properties depend principally on the manganese chloride and ammonium chloride concentrations of the electrolyte and temperature. A lower temperature results in a higher cathodic current efficiency and better deposit quality. So the operation temperature of electrorefining is maintained at $-10{ }^{\circ} \mathrm{C}$ to obtain adherent, compact and higher purity manganese. The temperature range of the physical properties tests is from $-10{ }^{\circ} \mathrm{C}$ to $25^{\circ} \mathrm{C}$. A literature survey indicated a lack of consistent density, electrical conductivity, and viscosity data for these electrolytes, a void that is filled in part by the results of the present investigation.

In this chapter, densities of different concentrations of $\mathrm{MnCl}_{2}-\mathrm{NH}_{4} \mathrm{Cl}$ solutions at $25{ }^{\circ} \mathrm{C}$ were tested (See Section 3.3); accordingly, specific conductivities and viscosities of different concentrations of $\mathrm{MnCl}_{2}-\mathrm{NH}_{4} \mathrm{Cl}$ solutions at different temperatures were then undertaken (See Section 3.4 and Section 3.5); finally, some conclusions for this physical properties study were provided (See Section 3.6). 


\subsection{Materials and Solutions}

In this study, the electrolyte solutions used throughout the work were prepared from analytical reagent grade manganese (II) chloride tetrahydrate $\left(\mathrm{MnCl}_{2} \bullet 4 \mathrm{H}_{2} \mathrm{O}\right)$ and ammonium chloride $\left(\mathrm{NH}_{4} \mathrm{Cl}\right)$ with deionized water. Manganese (II) chloride tetrahydrate $\left(\mathrm{MnCl}_{2} \bullet 4 \mathrm{H}_{2} \mathrm{O}\right)$ and ammonium chloride $\left(\mathrm{NH}_{4} \mathrm{Cl}\right)$ were provided by Fisher Scientific and Alfa Aesar respectively. Test solutions were synthesized from manganese chloride and ammonium chloride solutions. Viscosity standard solution (5000 cps) was shipped from Fisher Scientific and conductivity standard solution $(1413 \mathrm{mS} / \mathrm{cm})$ was provided by Ricca Chemical.

\subsection{Density Studies}

Densities were measured with a standard $25 \mathrm{ml}$ pycnometer with three measurements taken for each reported value. The measurements were converted from specific gravities to density values. The pycnometer (Figure 3.1) is a glass flask with a close-fitting ground glass stopper with a capillary hole through it. This fine hole releases excess liquid after closing a top-filled pycnometer and allows for obtaining a given volume of measured liquid with a high accuracy. Density tests were carried out at $25{ }^{\circ} \mathrm{C}$ for different concentrations of ammonium chloride and manganese chloride solutions. The procedure is described as follows:

- For each experiment, the clean dry bottle was weighed to the nearest $0.0001 \mathrm{~g}$

- The distilled water and test solutions were poured into the specific gravity bottle respectively until the bottle was completely full. Great care was taken to make sure that 
no bubbles remained in the pycnometer. Similarly the temperature was carefully monitored.

- The stopper was inserted so that the ground glass (frosted) end was in the bottle. The bottle was placed into the water bath and the temperature maintained at $25{ }^{\circ} \mathrm{C}$ for about 10 minutes. The outside of the bottle was then carefully dried with a tissue and weighed.

- The absolute density of the solution was calculated by reference to the water density values at $25^{\circ} \mathrm{C}$.

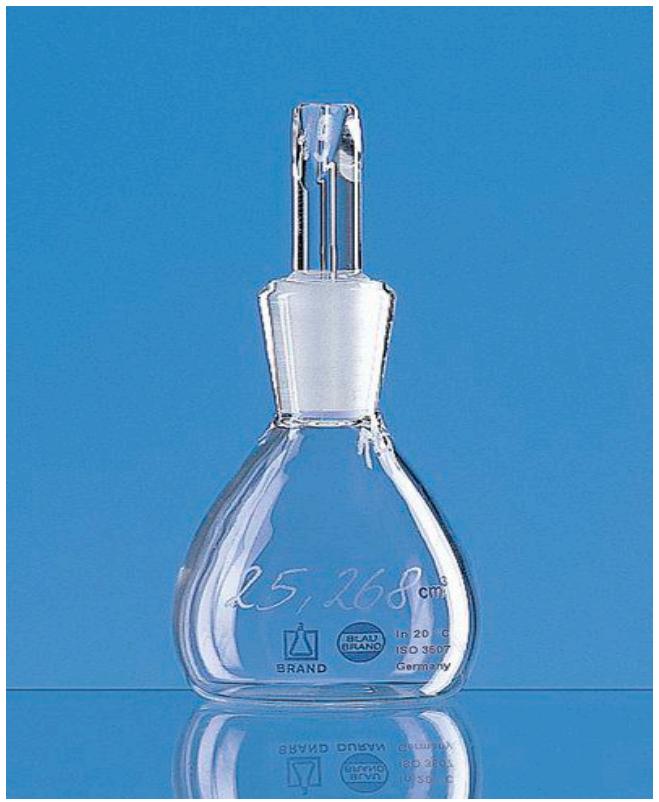

Figure 3.1 Glass Pycnometer

The experimental density measurements (See Figure 3.2) indicated that density could be expressed $\pm 1 \%$ as a function of the concentrations of the ammonium chloride and manganese chloride. The best-fit equation was found to be:

$d \pm 0.003=0.0989 \times\left[\mathrm{MnCl}_{2}\right]+0.0145 \times\left[\mathrm{NH}_{4} \mathrm{Cl}\right]+1.0104$ Equation 3.1

Where $\boldsymbol{d}$ is the absolute density, $\mathrm{g} \mathrm{cm}^{-3}$ at $25^{\circ} \mathrm{C}$. 


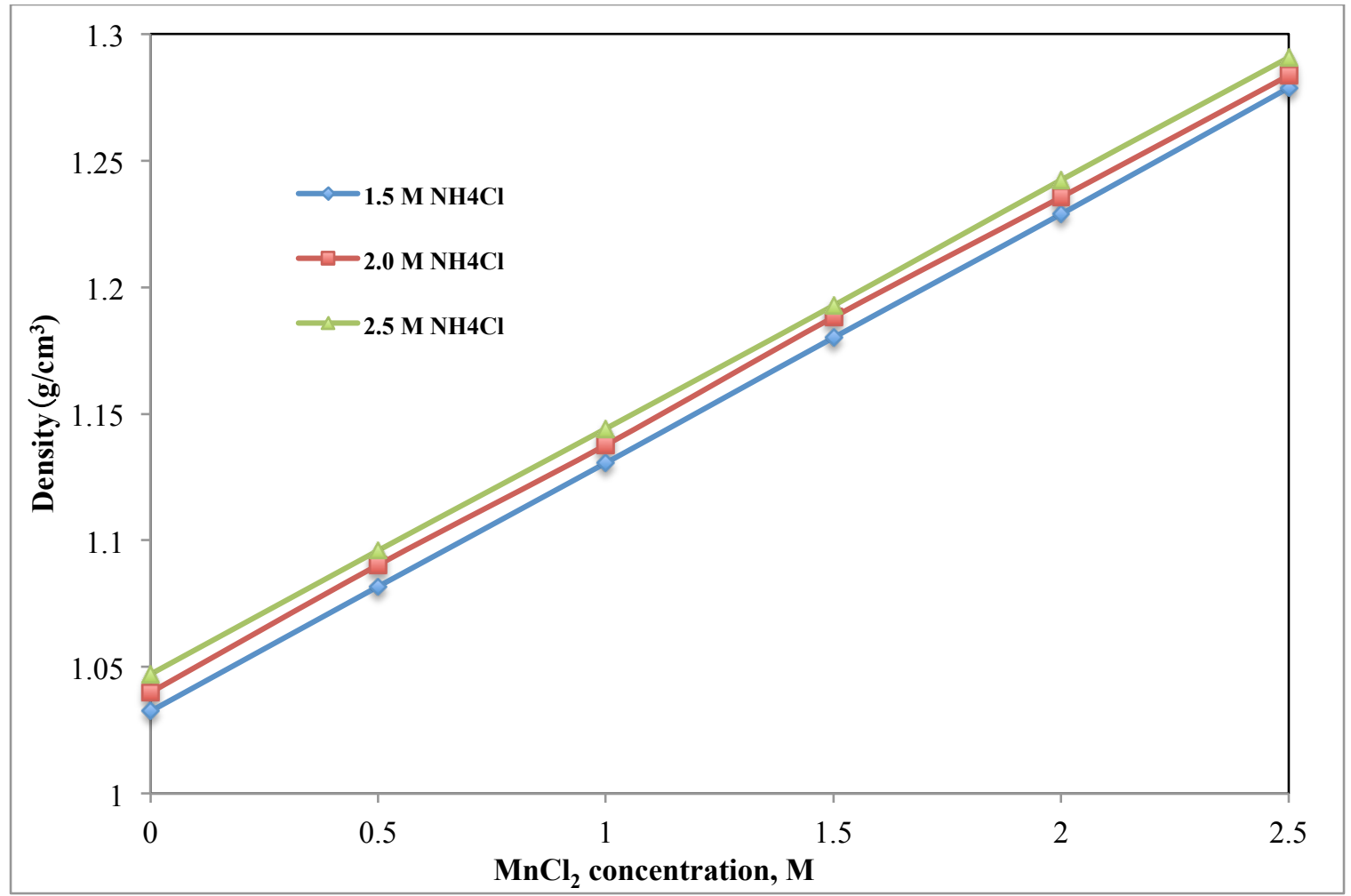

Figure 3.2 Densities of different concentrations of $\mathrm{MnCl}_{2}-\mathrm{NH}_{4} \mathrm{Cl}$ solutions at $25^{\circ} \mathrm{C}$

Noticeable from the present results (Figure 3.2) is the extremely small influence of ammonium chloride composition on density. The density of the solution is mainly dependent on the manganese chloride composition.

\subsection{Conductivity Studies}

Electrical conductivities were measured with a Jenway conductivity meter type 4320 with three measurements taken for each reported value in conjunction with a high conductivity cell. The cell was calibrated with a standard solution of $\mathrm{KCl}$ in doubly distilled, nitrogen degassed water at $25^{\circ} \mathrm{C} . \mathrm{KCl}$ conductivity values for the calibration were taken from the manufacturer. Conductivity tests were carried out at different temperatures $\left(-10{ }^{\circ} \mathrm{C}\right.$ to $\left.25{ }^{\circ} \mathrm{C}\right)$ for different 
concentrations of ammonium chloride and manganese chloride solutions. A thermostatted water bath was filled with water and ethylene glycol, covered with plastic foams and film to avoid loss of heat and water vapour. The water bath was used to maintain the temperature. The procedure is described as follows:

- The probe was connected to the rear panel socket and the cell rinsed thoroughly with deionized water to ensure it was clean and free from contamination.

- Before each test, the cell was calibrated with the standard $\mathrm{KCl}$ solution.

- Test solutions of about $50 \mathrm{~mL}$ were freshly prepared in a volumetric flask before each experiment. The solution was placed in test tubes and inserted into the water bath to establish the target temperature.

- The conductivity electrode was inserted into the test solution and jiggled up and down a few times to remove any bubbles from the probe. Care was taken not to bump the probe against the test tube walls.

- The conductivity measurement was recorded when the sample and electrode stabilized at the same temperature.

- The electrode was rinsed with distilled water and dabbed dry with a tissue between samples (without rubbing the electrode itself).

The conditions for the conductivity studies and the measured conductivities of the solutions are shown in Table 3.1 and Table 3.2. The results of the electrical conductivity measurements are plotted in Figure 3.3, Figure 3.4 and Figure 3.5. The solubility of $\mathrm{MnCl}_{2}$ is higher than that of $\mathrm{NH}_{4} \mathrm{Cl}$ at low temperature. Because they share the same anion $\mathrm{Cl}^{-}$, the $\mathrm{NH}_{4} \mathrm{Cl}$ will crystallize 
firstly at the low temperature when increasing the concentration of $\mathrm{NH}_{4} \mathrm{Cl}$ and $\mathrm{MnCl}_{2}$. So the value of the solutions $\left(2.5 \mathrm{M} \mathrm{MnCl}_{2}\right.$ and $\left.2.5 \mathrm{M} \mathrm{NH}{ }_{4} \mathrm{Cl}\right)$ could not be tested at $-10{ }^{\circ} \mathrm{C}$.

Table 3.1 Experimental conditions for the conductivity studies

\begin{tabular}{|l|l|}
\hline Temperature & $-10{ }^{\circ} \mathrm{C} /-5{ }^{\circ} \mathrm{C} / 0{ }^{\circ} \mathrm{C} / 5{ }^{\circ} \mathrm{C} / 10{ }^{\circ} \mathrm{C} / 15^{\circ} \mathrm{C} / 20^{\circ} \mathrm{C} / 25^{\circ} \mathrm{C}$ \\
\hline Manganese chloride concentration $\left(\mathrm{MnCl}_{2}\right)$ & $0 \mathrm{M} / 0.5 \mathrm{M} / 1 \mathrm{M} / 1.5 \mathrm{M} / 2 \mathrm{M} / 2.5 \mathrm{M}$ \\
\hline Ammonium chloride concentration $\left(\mathrm{NH}_{4} \mathrm{Cl}\right)$ & $1.5 \mathrm{M} / 2 \mathrm{M} / 2.5 \mathrm{M}$ \\
\hline
\end{tabular}

Table 3.2 Measured conductivities of $\mathrm{MnCl}_{2}-\mathrm{NH}_{4} \mathrm{Cl}$ solutions at different temperatures

Concentration (M)

\begin{tabular}{rrrrrrrrrr}
\hline $\mathrm{NH}_{4} \mathrm{Cl}$ & $\mathrm{MnCl}_{2}$ & $-10{ }^{\circ} \mathrm{C}$ & $-5{ }^{\circ} \mathrm{C}$ & $0{ }^{\circ} \mathrm{C}$ & \multicolumn{1}{c}{${ }^{\circ} \mathrm{C}$} & $10{ }^{\circ} \mathrm{C}$ & $15{ }^{\circ} \mathrm{C}$ & $20{ }^{\circ} \mathrm{C}$ & $25{ }^{\circ} \mathrm{C}$ \\
\hline 1.5 & 0 & 64.2 & 74.1 & 83.8 & 93.5 & 103.4 & 113.8 & 123.8 & 133.8 \\
1.5 & 0.5 & 75.2 & 86.9 & 98.2 & 109.8 & 121.3 & 133.3 & 144.9 & 156.9 \\
1.5 & 1 & 80.9 & 92.8 & 104.4 & 116.2 & 128.2 & 140.6 & 152.8 & 165.3 \\
1.5 & 1.5 & 78.6 & 90.6 & 102.1 & 114 & 126.1 & 138.4 & 150.7 & 163 \\
1.5 & 2 & 71.4 & 82.8 & 94 & 105.4 & 117.2 & 129.2 & 141.2 & 153 \\
1.5 & 2.5 & 60.7 & 71.5 & 81.9 & 92.9 & 103.5 & 114.8 & 126.2 & 137.2 \\
\hline 2 & 0 & 85.6 & 97.4 & 109.5 & 121.3 & 132.9 & 145.2 & 157.6 & 170.3 \\
2 & 0.5 & 91.8 & 105 & 117.9 & 132.3 & 145.7 & 158.9 & 172.8 & 186.7 \\
2 & 1 & 93.2 & 106.3 & 119.5 & 133.7 & 147.3 & 160.5 & 174.5 & 188.3 \\
2 & 1.5 & 88.8 & 101.1 & 113.7 & 127.2 & 140.5 & 153.8 & 167.5 & 181.2 \\
2 & 2 & 78.2 & 90.8 & 102.9 & 115 & 127.7 & 140.4 & 153.4 & 166.7 \\
2 & 2.5 & 67.2 & 77.8 & 89 & 100.6 & 112.2 & 123.6 & 135.3 & 146.9 \\
\hline 2.5 & 0 & 106 & 119.6 & 133.5 & 147.2 & 161.7 & 176.2 & 190.7 & 205 \\
2.5 & 0.5 & 109.5 & 124.2 & 138.6 & 153.5 & 168.3 & 183.1 & 197.7 & 213 \\
2.5 & 1 & 107.1 & 121 & 135 & 149.5 & 164 & 178.9 & 193.6 & 209 \\
2.5 & 1.5 & 97.1 & 111.2 & 124.6 & 138.5 & 152.5 & 166.8 & 181.2 & 195.2 \\
2.5 & 2 & 83.9 & 97.3 & 109.7 & 122.7 & 135.8 & 149.4 & 163 & 176.2 \\
2.5 & 2.5 & - & 80.1 & 92.3 & 103.9 & 116.5 & 128.4 & 140.8 & 154 \\
\hline & & & & & & & & & 44
\end{tabular}

\section{Specific conductivity $(\mathrm{mS} / \mathrm{cm})$}




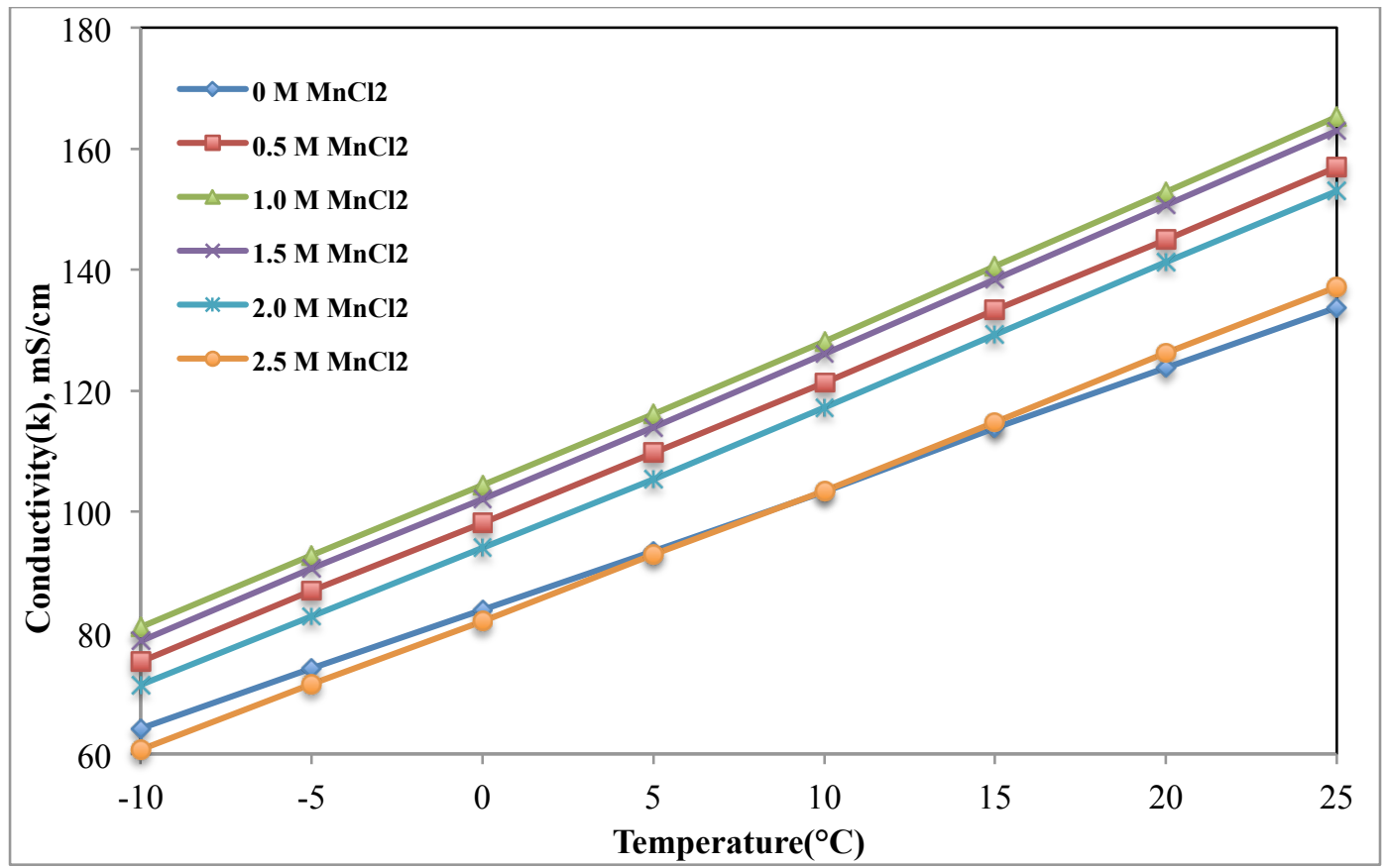

Figure 3.3 Specific conductivities of $\mathrm{MnCl}_{2}-1.5 \mathrm{M} \mathrm{NH}_{4} \mathrm{Cl}$ solutions at different temperatures

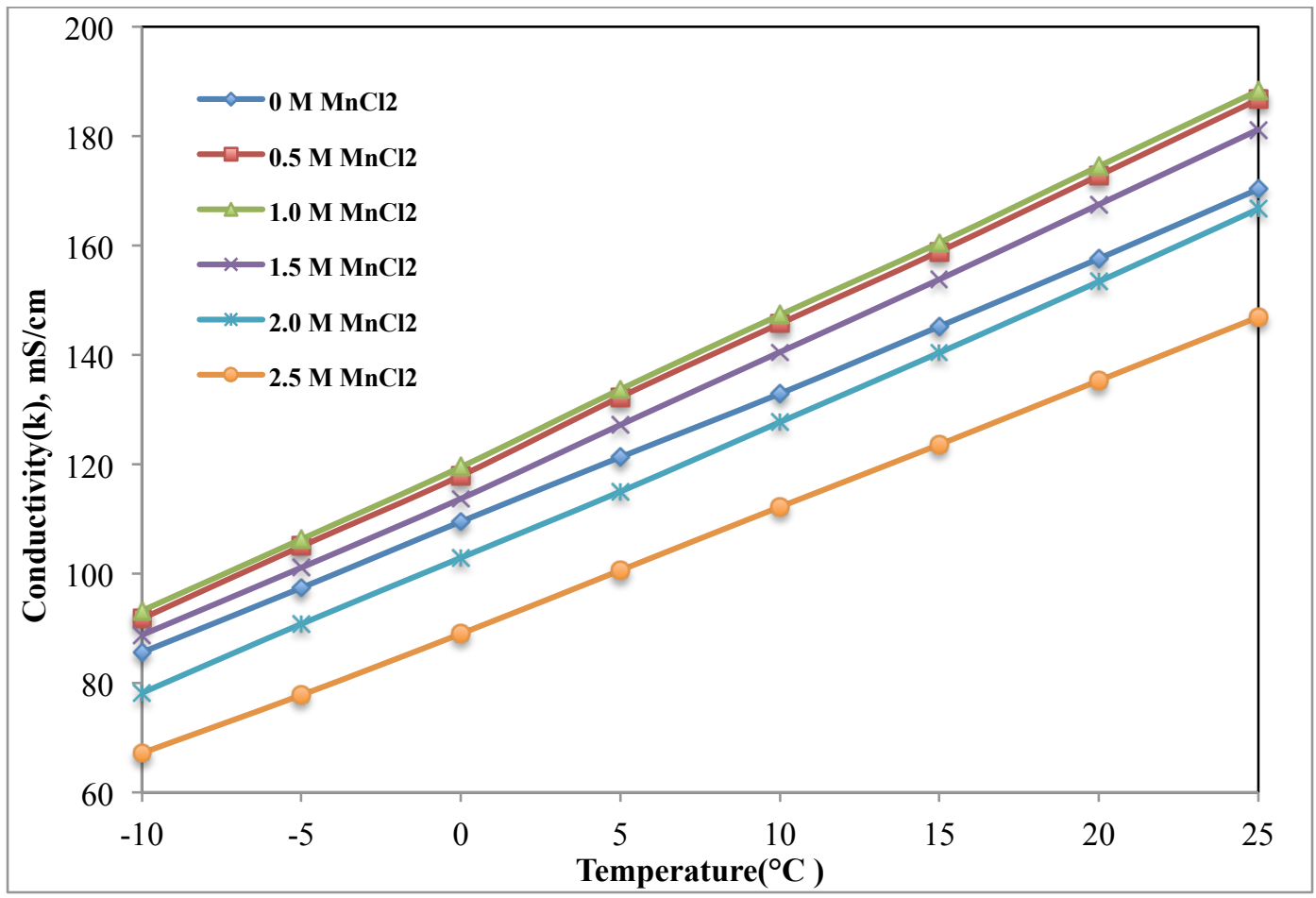

Figure 3.4 Specific conductivities of $\mathrm{MnCl}_{2}-2.0 \mathrm{M} \mathrm{NH}_{4} \mathrm{Cl}$ solutions at different temperatures 


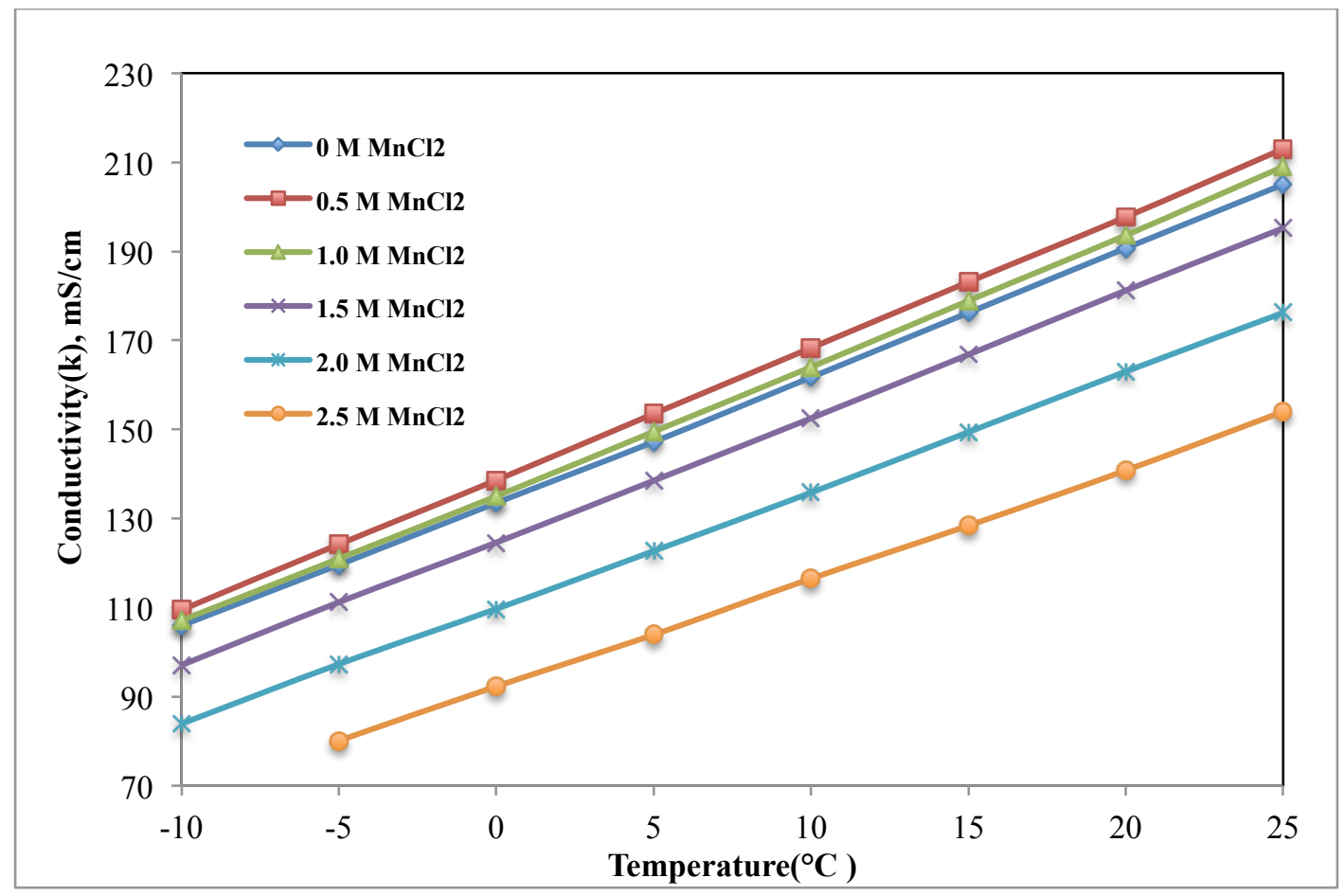

Figure 3.5 Specific conductivities of $\mathrm{MnCl}_{2}-2.5 \mathrm{M} \mathrm{NH}{ }_{4} \mathrm{Cl}$ solutions at different temperatures

A mathematical model for all the conductivities in equation form as a function of temperature, $\mathrm{MnCl}_{2}$ and $\mathrm{NH}_{4} \mathrm{Cl}$ concentrations developed using of SPSS statistical software could be expressed as:

$$
k=-13.638 \times\left[\mathrm{MnCl}_{2}\right]^{2}+24.582 \times\left[\mathrm{MnCl}_{2}\right]+32.058 \times\left[\mathrm{NH}_{4} \mathrm{Cl}\right]+2.522 \times \mathrm{T}+45.154 \quad \text { Equation } 3.2
$$

Where $\boldsymbol{k}$ represents the measured conductivity values $(\mathrm{mS} / \mathrm{cm}) \pm 3 \%,\left[\mathrm{MnCl}_{2}\right]$ and $\left[\mathrm{NH}_{4} \mathrm{Cl}\right]$ are concentrations of manganese chloride and ammonium chloride in mol/L, and $\boldsymbol{T}$ is temperature ${ }^{\circ} \mathrm{C}$.

From Table 3.2, it was found that the strongest influence on electrical conductivity was the temperature, due to the increased mobility of the ions with the high temperature. From the figures above, the conductivity of solution was a parabolic function of the manganese chloride concentration. When the manganese chloride concentration was at the highest value of $2.5 \mathrm{M}$, the 
conductivity of solution slightly decreased. This is probably because at high concentrations the mobility of the ions is reduced due to ion-ion interactions leading to aggregation and clustering. When increasing the ammonium chloride concentration from $1.5 \mathrm{M}$ to $2.5 \mathrm{M}$ at a fixed temperature, the solution conductivity would increase. From Figure 3.3 and Figure 3.4, when the manganese chloride concentration was at $1 \mathrm{M}$, the solution conductivity reached the maximum at a fixed temperature. From Figure 3.5, when the manganese chloride reached $0.5 \mathrm{M}$, the solution conductivity obtained the maximum at a fixed temperature.

In practical applications, it is desirable to employ relatively high conductivity levels since minimum power consumption during electrolysis is obtained at maximum electrical conductivity. From this point of view it is clear that electrorefining should be carried out with as high as possible concentration of ammonium chloride solution and temperature.

\subsection{Viscosity Studies}

Viscosities were determined by means of a Brookfield viscometer, Model LVDV-III with LV2 spindle (entry code $62, \mathrm{SMC}=32, \mathrm{SRC}=0$ ). The viscometer was calibrated with standard solutions (See Appendix A). Viscosity tests were carried out at different temperatures $\left(-10{ }^{\circ} \mathrm{C}\right.$ to $\left.25^{\circ} \mathrm{C}\right)$ for different concentrations of ammonium chloride and manganese chloride solutions. The water bath was used to keep the temperature. The procedure is described as follows:

- $\quad$ Set up the DV-III and leveled the head to make sure the instrument was zeroed.

- Before each test, the viscometer was calibrated with the standard solution. 
- Test solutions of about $500 \mathrm{~mL}$ were freshly prepared in a volumetric flask before each experiment. The solution was placed into the container and inserted them into the water bath to maintain the temperature.

- The DV-III was lowered into the measurement position (with guard leg) and the spindle attached to the viscometer.

- The solution, together with the spindle had to be immersed in the bath for a minimum half hour if the temperature was below $10{ }^{\circ} \mathrm{C}$ in order to obtain a stable reading.

- When the solution was at the test temperature $\left(+/-0.1{ }^{\circ} \mathrm{C}\right.$ of the specific temperature $)$, the viscosity was measured and recorded.

- The spindle had to be rotated at least five times before a viscosity reading was taken.

The conditions for the viscosities studies and the measured viscosities of $\mathrm{MnCl}_{2}-\mathrm{NH}_{4} \mathrm{Cl}$ solutions at different temperatures are shown in Table 3.3 and Table 3.4. The results of the viscosity measurements are presented in Figure 3.6, Figure 3.7 and Figure 3.8. The viscosities displayed an Arrhenius temperature dependence over the approximate temperature range $-10{ }^{\circ} \mathrm{C}-25^{\circ} \mathrm{C}$ :

$$
\eta=\eta_{o} \exp \left(\frac{E_{\eta}}{R T}\right)
$$

Where $E_{\eta}$ is the energy of activation for viscous flow $(\mathrm{KJ} / \mathrm{mol}), R$ is the gas constant $\left(\mathrm{J} \cdot \mathrm{mol}^{-1} \cdot \mathrm{K}^{-}\right.$ $\left.{ }^{1}\right)$, and $T$ is the absolute temperature $(\mathrm{K})$. These graphs indicated that the temperature had a strong effect on the viscosity. When increasing the temperature, the viscosity of the solution could decrease (See Figure 3.6, 3.7 and 3.8). From the handbook[73], it was found that the viscosity of ammonium chloride solution decreases initially and then increases when increasing 
the ammonium chloride concentration. For the viscosity for the manganese chloride solution, it increases when increasing the concentration of manganese chloride[74].

Table 3.3 Experimental conditions for the viscosity studies

\begin{tabular}{|l|l|}
\hline Temperature & $-10{ }^{\circ} \mathrm{C} /-5{ }^{\circ} \mathrm{C} / 0{ }^{\circ} \mathrm{C} / 5{ }^{\circ} \mathrm{C} / 10{ }^{\circ} \mathrm{C} / 15{ }^{\circ} \mathrm{C} / 20{ }^{\circ} \mathrm{C} / 25{ }^{\circ} \mathrm{C}$ \\
\hline Manganese chloride concentration $\left(\mathrm{MnCl}_{2}\right)$ & $0 \mathrm{M} / 0.5 \mathrm{M} / 1 \mathrm{M} / 1.5 \mathrm{M} / 2 \mathrm{M} / 2.5 \mathrm{M}$ \\
\hline Ammonium chloride concentration $\left(\mathrm{NH}_{4} \mathrm{Cl}\right)$ & $1.5 \mathrm{M} / 2 \mathrm{M} / 2.5 \mathrm{M}$ \\
\hline
\end{tabular}

Table 3.4 Measured viscosities of $\mathrm{MnCl}_{2}-\mathrm{NH}_{4} \mathrm{Cl}$ solutions at different temperatures

\begin{tabular}{|c|c|c|c|c|c|c|c|c|c|}
\hline \multicolumn{2}{|c|}{ Concentration (M) } & \multicolumn{8}{|c|}{ Viscosity (cp) } \\
\hline $\mathrm{NH}_{4} \mathrm{Cl}$ & $\mathrm{MnCl}_{2}$ & $-10^{\circ} \mathrm{C}$ & $-5^{\circ} \mathrm{C}$ & $0{ }^{\circ} \mathrm{C}$ & $5^{\circ} \mathrm{C}$ & $10^{\circ} \mathrm{C}$ & $15^{\circ} \mathrm{C}$ & $20^{\circ} \mathrm{C}$ & $25^{\circ} \mathrm{C}$ \\
\hline 1.5 & 0 & 10.8 & 9.3 & 8.1 & 7.1 & 6.2 & 5.4 & 4.8 & 4.3 \\
\hline 1.5 & 0.5 & 12 & 10.6 & 9.4 & 8.4 & 7.5 & 6.7 & 6.1 & 5.5 \\
\hline 1.5 & 1 & 12.3 & 11.1 & 10.1 & 9.2 & 8.4 & 7.7 & 7.1 & 6.5 \\
\hline 1.5 & 1.5 & 13.3 & 12 & 10.9 & 10 & 9.2 & 8.4 & 7.7 & 7.1 \\
\hline 1.5 & 2 & 15.7 & 14.2 & 12.9 & 11.7 & 10.7 & 9.8 & 9 & 8.3 \\
\hline 1.5 & 2.5 & 18.2 & 16.5 & 15 & 13.7 & 12.5 & 11.5 & 10.6 & 9.8 \\
\hline 2 & 0 & 10.7 & 9.2 & 7.9 & 6.8 & 5.9 & 5.1 & 4.5 & 4 \\
\hline 2 & 0.5 & 11.6 & 10.1 & 8.9 & 7.8 & 6.9 & 6.2 & 5.5 & 4.9 \\
\hline 2 & 1 & 11.9 & 10.7 & 9.7 & 8.8 & 8 & 7.3 & 6.7 & 6.2 \\
\hline 2 & 1.5 & 12.7 & 11.7 & 10.7 & 9.8 & 9 & 8.3 & 7.7 & 7.1 \\
\hline 2 & 2 & 14.7 & 13.5 & 12.4 & 11.4 & 10.5 & 9.7 & 8.9 & 8.3 \\
\hline 2 & 2.5 & 17 & 15.6 & 14.4 & 13.3 & 12.3 & 11.5 & 10.6 & 9.8 \\
\hline 2.5 & 0 & 9.7 & 8.4 & 7.3 & 6.4 & 5.6 & 4.9 & 4.3 & 3.8 \\
\hline 2.5 & 0.5 & 10.5 & 9.2 & 8.2 & 7.3 & 6.5 & 5.8 & 5.2 & 4.7 \\
\hline 2.5 & 1 & 11.3 & 10.2 & 9.2 & 8.3 & 7.6 & 6.9 & 6.3 & 5.8 \\
\hline 2.5 & 1.5 & 12.9 & 11.7 & 10.6 & 9.7 & 8.9 & 8.1 & 7.5 & 6.9 \\
\hline 2.5 & 2 & 15.3 & 14 & 12.8 & 11.8 & 10.9 & 10.1 & 9.4 & 8.7 \\
\hline 2.5 & 2.5 & - & 16.8 & 15.4 & 14.2 & 13.1 & 12.1 & 11.2 & 10.5 \\
\hline
\end{tabular}




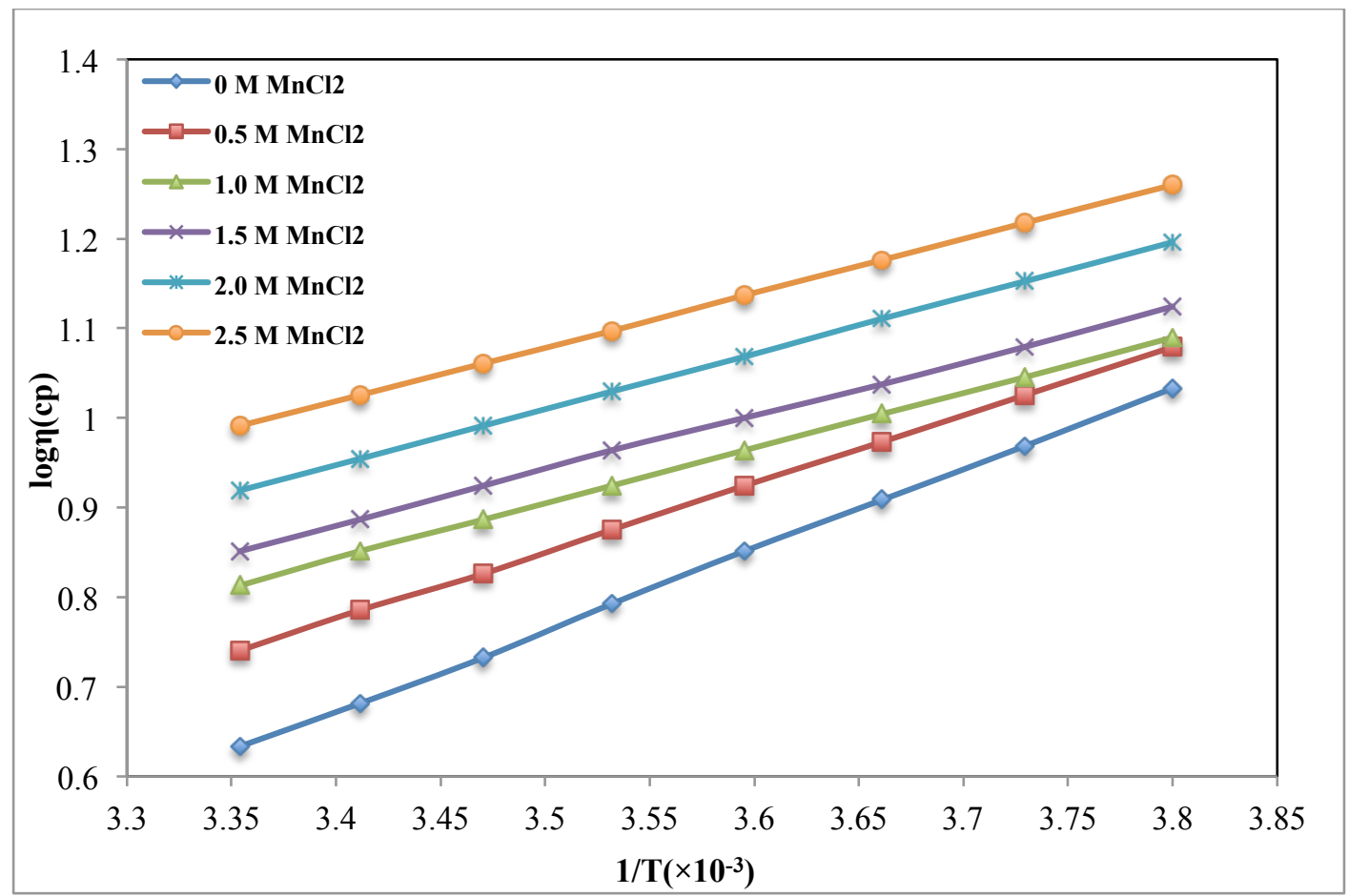

Figure 3.6 Arrhenius plots of viscosity of $\mathrm{MnCl}_{2}-1.5 \mathrm{M} \mathrm{NH}_{4} \mathrm{Cl}$ solutions at different temperatures

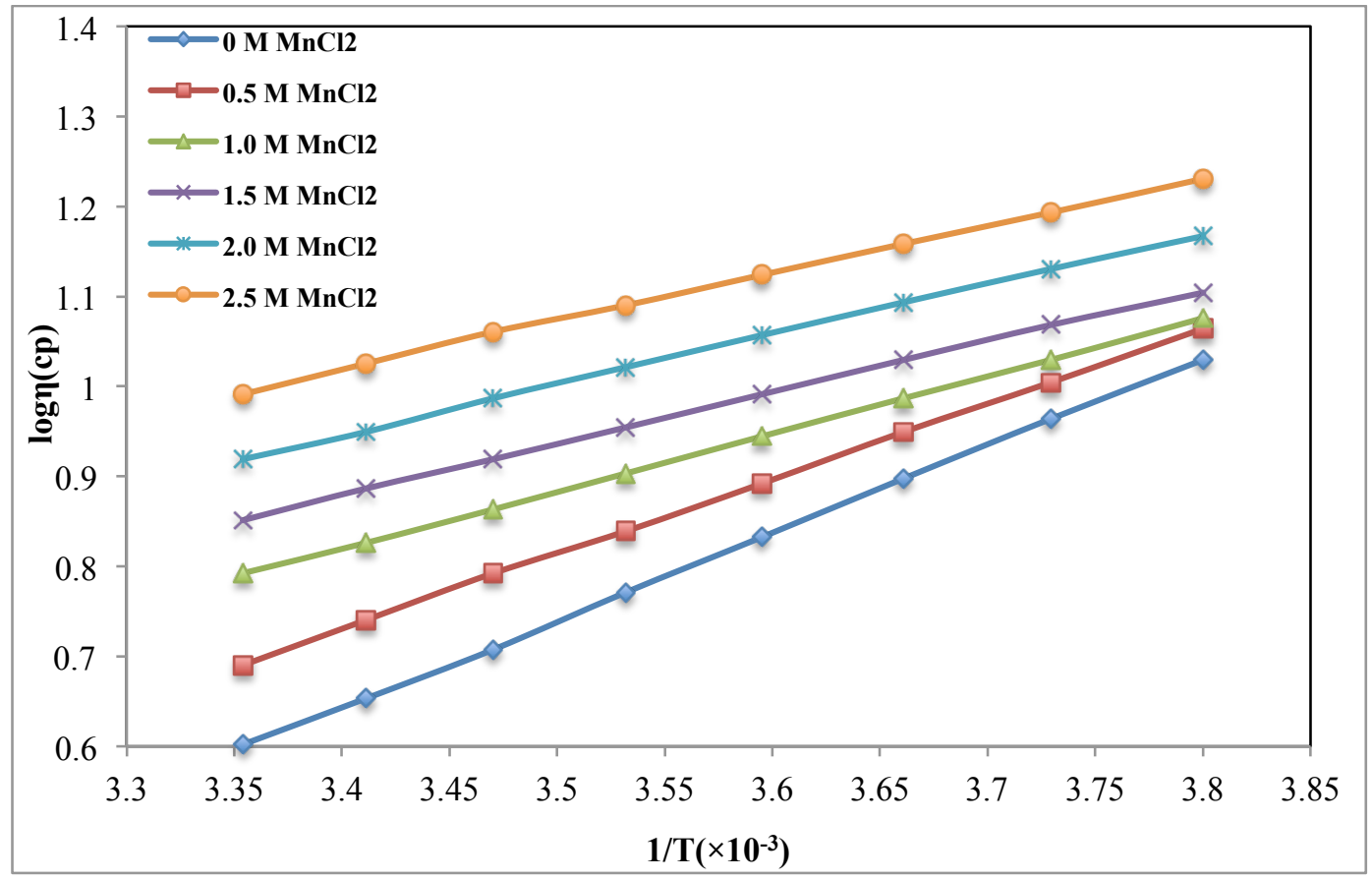

Figure 3.7 Arrhenius plots of viscosity of $\mathrm{MnCl}_{2}-2.0 \mathrm{M} \mathrm{NH}_{4} \mathrm{Cl}$ solutions at different temperatures 


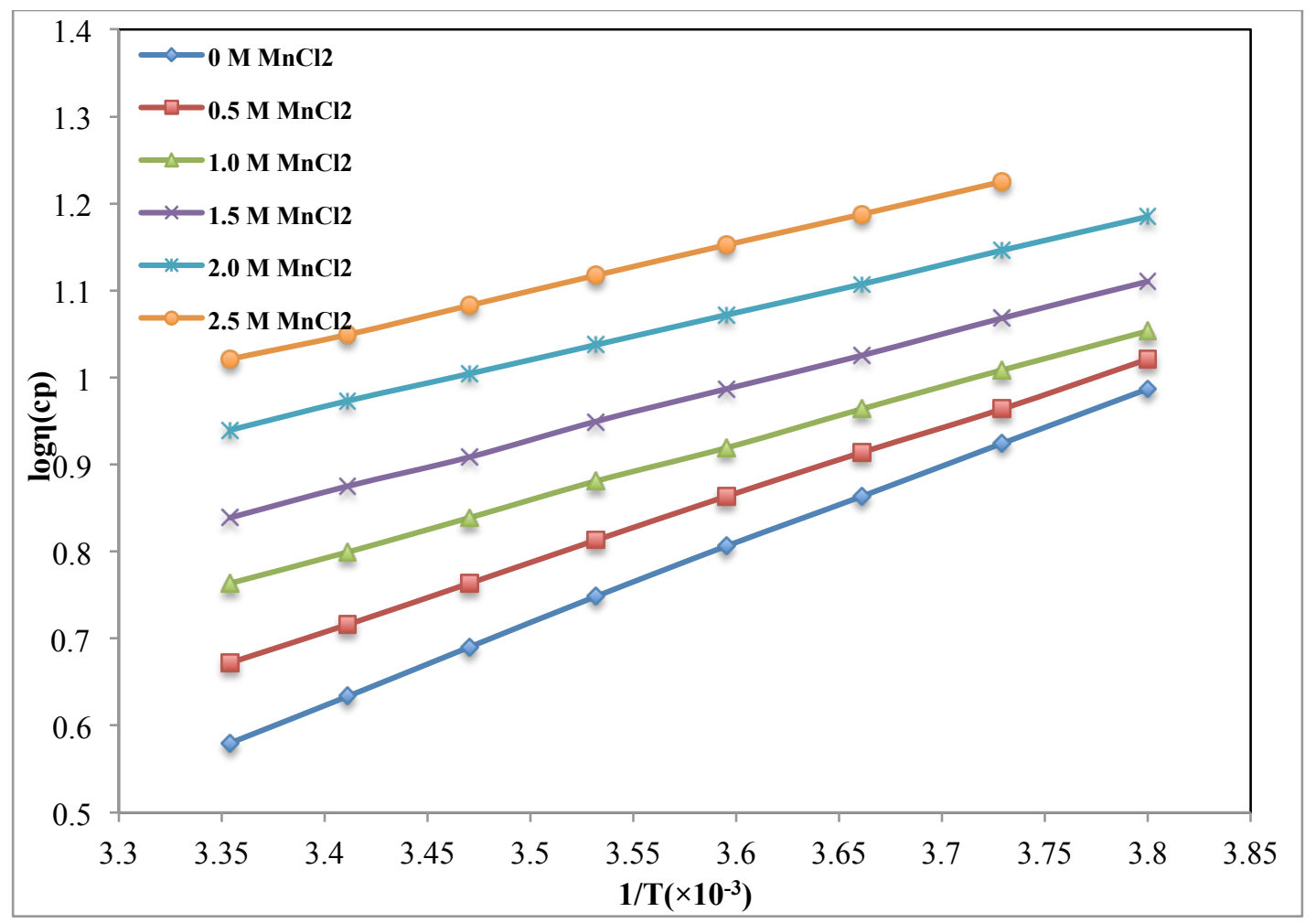

Figure 3.8 Arrhenius plots of viscosity of $\mathrm{MnCl}_{2}-2.5 \mathrm{M} \mathrm{NH}_{4} \mathrm{Cl}$ solutions at different temperatures

From tables and figures above, it was clearly demonstrated that both $\mathrm{MnCl}_{2}$ and $\mathrm{NH}_{4} \mathrm{Cl}$ concentrations could affect viscosity. It is also affected significantly by temperature. It was found that increasing the manganese chloride concentration could increase the solution viscosity. From these three graphs, when the manganese chloride concentration was at $2.5 \mathrm{M}$, the solution viscosity reached the maximum at a fixed temperature. When the ammonium chloride concentration increased, the viscosity of the solution decreased firstly and then increased.

Expression of viscosity in equation form as a function of temperature, $\mathrm{MnCl}_{2}$ and $\mathrm{NH}_{4} \mathrm{Cl}$ concentrations can be expressed as: 
Where $\boldsymbol{\eta}$ represents the measured viscosity values (cp) $\pm 2 \%,\left[\mathrm{MnCl}_{2}\right]$ and $\left[\mathrm{NH}_{4} \mathrm{Cl}\right]$ are concentrations of manganese chloride and ammonium chloride in mol/L, and $\mathbf{T}$ is temperature $\mathrm{K}$. The calculated and tested values are compared in Figure 3.9 and show very good agreement (Adj. R-Square $=0.971)$. The relative mean square of errors was calculated as 0.2522 by equation below.

$$
E . R .=\left[\frac{1}{N} \sum_{i}^{N} \frac{\left(\log \eta_{1}-\log \eta_{2}\right)^{2}}{\left(\log \eta_{1}\right)^{2}}\right]^{0.5}
$$

$\eta_{1}$ - Calculated results; $\eta_{2}$-Experimental results

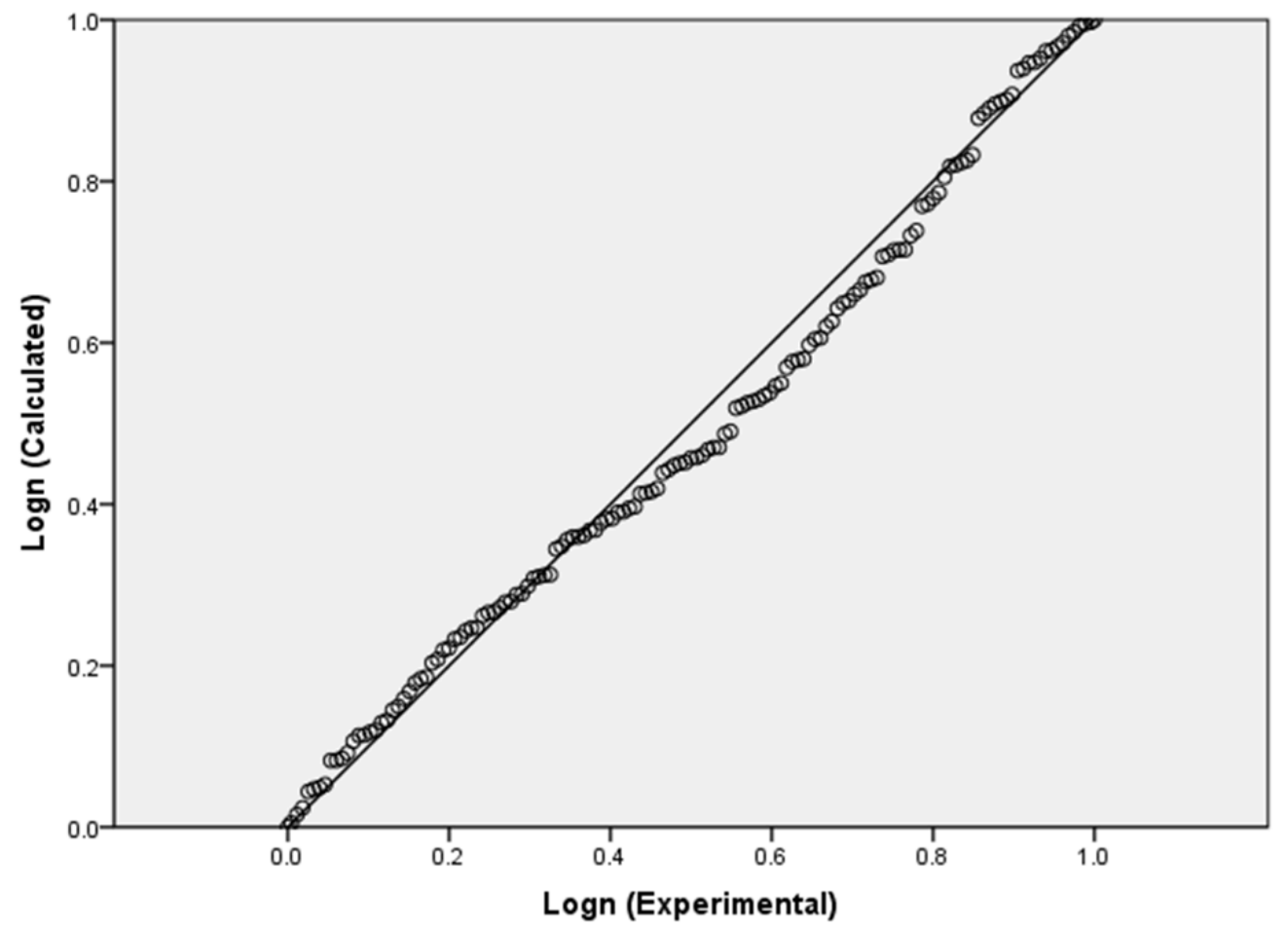

Figure 3.9 Comparison of calculated and tested values of viscosities 
In practical terms, the experimental data clearly show that viscosity is minimized by high temperature and by low concentrations of manganese chloride.

\subsection{Summary}

Measurements of electrical conductivities, densities and viscosities of $\mathrm{MnCl}_{2}-\mathrm{NH}_{4} \mathrm{Cl}$ solutions indicate that:

(1) The density increases when increasing the concentrations of the ammonium chloride and manganese chloride at room temperature. The density of the solution is mainly dependent on the manganese chloride composition.

(2) Maximum electrical conductivity, which is desirable for minimum power consumption, is obtained with high concentrations of ammonium chloride and high temperature.

(3) Viscosity is minimized by high temperature and by low concentrations of manganese chloride.

(4) In general, electrorefining should be carried out under conditions of high electrical conductivity and low viscosity. These conditions are both promoted by higher temperatures. 


\section{Chapter 4: Purification by Cementation and Ion Exchange}

\subsection{Introduction}

During electrorefining, some impurities will be partially dissolved with manganese in the anode compartment (in proportion to the purity of the anode). These impurities have to be removed before the anolyte is circulated to the cathode compartment. There are many purification methods such as hydrolytic precipitation, sulfide precipitation, electrochemical methods, cementation, and ion exchange. The precipitation of metals in solution as metal hydroxides is the most common way to remove metals from solutions in hydrometallurgical processes. But hydrolytic precipitation can only remove some impurities to a fixed level. It cannot be used for the level of purification required to achieve the high purity Mn metal[17]. Similarly the precipitation and separation of metal sulfides from manganese is based on different sulfide solubilities of metals at certain $\mathrm{pH}$ and temperature values. Sulfide precipitation can effectively remove heavy metal impurities $(\mathrm{Ni}, \mathrm{Co}, \mathrm{Cu}$, etc.). However sulfur from sulfides may be introduced to the manganese deposit if residual sulfide ion (or oxidation products) remains in the purified solution. Therefore cementation and ion exchange may be the most suitable technologies for this purification application. Manganese powder is used to remove impurities by cementation as the manganese metal reduction potential is lower than all other metal reduction potentials $(\mathrm{Co}$, $\mathrm{Ni}, \mathrm{Cu}, \mathrm{Zn}$, etc.).

In this chapter, the feasibility of impurity removal by cementation with manganese powder was studied (See Section 4.4); in addition, the equilibrium studies of the Lewatit ${ }^{\circ}$ MDS TP220 and 
Purolite S930Plus resins were investigated (See Section 4.5); the column studies for these two ion exchange resins were then undertaken (See Section 4.6); finally, some conclusions in this part of study were given (See Section 4.7).

\subsection{Materials and Solutions}

Dr. Guobao Chen previously investigated the application of different resins at $\mathrm{pH} 5$ to remove ionic impurities. According to Guobao, Lewatit ${ }^{\circledR}$ MDS TP220 and Purolite S930Plus resins were selected as the key resins. In this work, all the experiments were carried out using the manufactured ion exchange resins (Lewatit® MDS TP220 and Purolite S930Plus) to investigate the loading behavior of metal ions $\left(\mathrm{Cu}^{2+}, \mathrm{Ni}^{2+}, \mathrm{Cd}^{2+}, \mathrm{Zn}^{2+}, \mathrm{Mn}^{2+}\right.$ and $\left.\mathrm{Co}^{2+}\right)$. The properties of commercial chelating resins have been illustrated in Table 4.1[75]. The resins are used for ion exchange experiments in either the hydrogen or sodium form. For the objective of this work, the as-received resin was converted to the hydrogen form following the manufacturer's recommended procedure. To convert the resin to the hydrogen form, the resins were washed with $2 \mathrm{M} \mathrm{HCl}$ followed by deionized water rinse. After conditioning, the resin sample was poured into a graduated cylinder filled partially with deionized water. The graduated cylinder was vibrated until the settled volume of resin remained unchanged. This procedure was repeated twice for one resin sample and showed good repeatability. The resin was then poured into a container of known weight and the excess water removed by applying vacuum to a small porous cylinder placed in the container. The container of resin was then weighed and a bulk density calculated. All resin volumes reported in this thesis were obtained by weighing out an appropriate amount of resin based on this bulk density calculation. 
The synthetic electrolyte feed solutions for batch tests consisted of $2 \mathrm{~mol} / \mathrm{L}$ manganese chloride, $2 \mathrm{~mol} / \mathrm{L}$ ammonium chloride and $100 \mathrm{ppb}$ impurities, and for the column tests consisted of 2 mol/L manganese chloride, $2 \mathrm{~mol} / \mathrm{L}$ ammonium chloride and $200 \mathrm{ppb}$ impurities. Manganese chloride solution for the batch and loading tests was obtained by the following steps: first dissolving manganese metal ( $>99.9 \%$ pure) from Manganese Metal Company in South Africa with a $12 \mathrm{~mol} / \mathrm{L} \mathrm{HCl}$ solution, and then remove impurities $(\mathrm{Cu}, \mathrm{Co}, \mathrm{Ni}, \mathrm{Pb}, \mathrm{Cr}$ and etc.) by cementation. ACS reagent grade metal chloride salts were used $\left(\mathrm{ZnCl}_{2}, \mathrm{CuCl}_{2}, \mathrm{NiCl}_{2}\right.$, $\mathrm{CdCl}_{2} \cdot 5 / 2 \mathrm{H}_{2} \mathrm{O}$ and $\mathrm{CoCl}_{2}$ from Fisher Chemicals) to add the target impurities. The ammonium chloride solutions were prepared from analytical grade reagents. The $\mathrm{pH}$ was then adjusted using $\mathrm{NH}_{4} \mathrm{OH}$ or $\mathrm{HCl}$ (certified, Fisher Chemicals).

Table 4.1 Properties of commercial chelating resins

\begin{tabular}{|l|c|c|}
\hline & Purolite S930Plus & Lewatit@ MDS TP 220 \\
\hline Polymer Structure & Macroporous crosslinked polymer & Macroporous crosslinked polystyrene \\
\hline Ionic Form as Shipped & $\mathrm{Na}^{+}$ & Fully protonated \\
\hline Appearance & Spherical Beads & Opaque \\
\hline Functional group & Iminodiacetic acid & Bis-picolylamine \\
\hline Particle size $(\mu \mathrm{m})$ & $425-1000$ & 620 \\
\hline Bed density $(\mathrm{g} / \mathrm{L})$ & $750-800$ & 690 \\
\hline Particle density $\left(\mathrm{g} / \mathrm{cm}^{3}\right)$ & 1.18 & 1.1 \\
\hline Moisture content $(\%)$ & $55-65$ & $50-58$ \\
\hline Operating temperature $\max \left({ }^{\circ} \mathrm{C}\right)$ & 80 & 70 \\
\hline Total Capacity $(\min )$. & $2.9 \mathrm{eq} / \mathrm{L}$ & $2.2 \mathrm{eq} / \mathrm{L}$ \\
\hline
\end{tabular}

\subsection{Manganous Ion Concentration Analysis}

The manganous ion concentration is based on the potentiometric titration of manganous ion with permanganate ion in neutral pyrophosphate solution, the +2 manganese being oxidized, and the 
permanganate ion reduced, to a pyrophosphate complex of the +3 state[76]. The stoichiometry of the reaction may be represented by:

$$
4 \mathrm{Mn}^{2+}+\mathrm{MnO}_{4}^{-}+8 \mathrm{H}^{+}+15 \mathrm{H}_{2} \mathrm{P}_{2} \mathrm{O}_{7}^{2-}=5 \mathrm{Mn}\left(\mathrm{H}_{2} \mathrm{P}_{2} \mathrm{O}_{7}\right)_{3}^{3-}+4 \mathrm{H}_{2} \mathrm{O} \quad \text { Reaction } 4.1
$$

For the standard solutions of manganous ion: after ion exchange, $10 \mathrm{ml}$ of the final solution was diluted with Milli-Q water into a $200 \mathrm{ml}$ volumetric flask. These dilute solutions were prepared immediately before use. The concentration of a purchased 0.02 molar potassium permanganate solutions (Fisher Scientific) was standardized against pure sodium oxalate. This was done by dissolving approximately $0.25 \mathrm{~g}$ of oxalate in $250 \mathrm{~mL}$ of water, acidify with sulfuric acid, warm to $70{ }^{\circ} \mathrm{C}$ and titrate to the first permanent pink[77]. The sodium pyrophosphate $\left(\mathrm{Na}_{4} \mathrm{P}_{2} \mathrm{O}_{7} \bullet 10 \mathrm{H}_{2} 0\right)$ was used in the form of freshly prepared solutions saturated at room temperature (6 grams per $100 \mathrm{ml})$. This analysis was carried out in two steps:

- The original $\mathrm{MnCl}_{2}$ solution $(4.7 \mathrm{~mol} / \mathrm{L})$ was diluted by adding $10 \mathrm{ml}$ of the original solution with Milli-Q water into a $200 \mathrm{ml}$ volumetric flask. Then $10 \mathrm{ml}$ of solution was pipetted into the container for the following titration step.

- A volume of 150-200 ml saturated sodium pyrophosphate solution was added into the container and adjusted to $\mathrm{pH} 7$ with $2 \mathrm{~mol} / \mathrm{L} \mathrm{HCl}$. Then titration was then performed using standard 0.02 molar potassium permanganate solutions.

The accuracy of the results was verified by potentiometric titrations that were performed using Metrohm 888 Titrando auto-titrant. Monitoring the potential of the solution during the addition of titrant is employed in this technique to detect the endpoint. Figure 4.1 shows an example of 
the electrolyte potential and ERC variations as a function of the titrant volume. The sharp increase in the electrolyte potential and the maximum value of the Endpoint Recognition Criterion (ERC) represents the end point of the titration (EP). Titration of each sample was carried out three times to ensure the obtained data is accurate and reproducible.

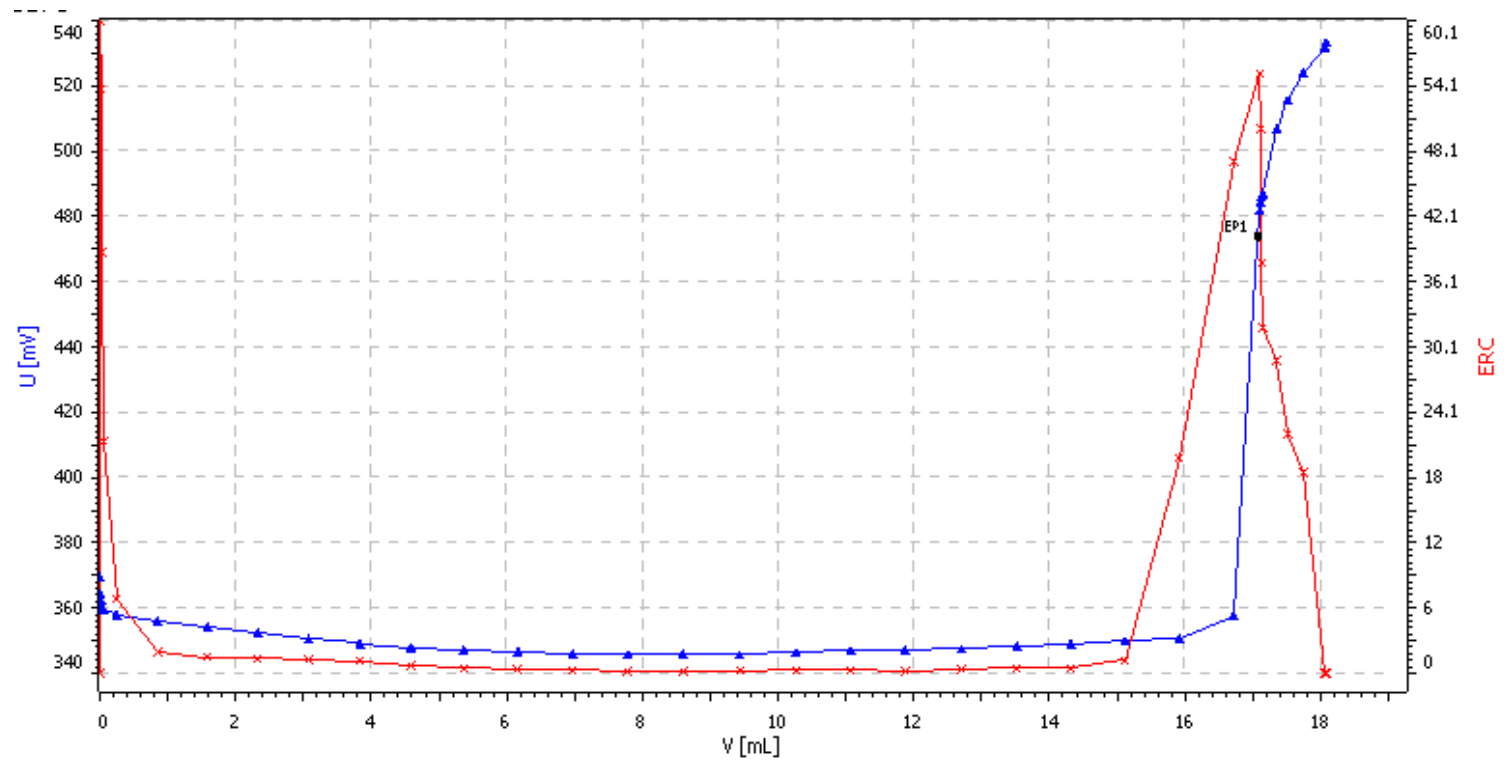

Figure 4.1 Potentiometric determinations of manganous ions with permanganate (blue $=$ titration curve, red

$$
\text { = ERC) }
$$

\subsection{Cementation Studies}

According to the electrochemical series (See Table 4.2), manganese provides a strong thermodynamic driving force for the cementation of more noble metals such as copper and cobalt. The greater the potential difference, the greater the thermodynamic driving force for the reaction[78]. So the cementation tests were performed using manganese powders for kinetic studies. To improve the reproducibility, a $600 \mathrm{ml}$ baffle reactor was used. The role of the baffles 
was to minimize the effects of vortexing. The $600 \mathrm{~mL}$ three-baffled glass reactor was manufactured by CanSci Glass Products Ltd. A high-density polyethylene lid manufactured by the machine shop in Materials Engineering, UBC, was used to seal the reactor. There were several openings on the lid for the experiment. The temperature was controlled by the cold running water to maintain at $13{ }^{\circ} \mathrm{C}$. To start an experiment, the solution was cooled while sparging with nitrogen gas to eliminate oxygen from the solution. The $\mathrm{pH}$ was maintained with reagent grade hydrochloric acid by using a $\mathrm{pH}$ controller. The electrolyte was agitated at 710 RPM by using a titanium stirring rod connected with a motor. During the test, the solution potentials were tested by a bright platinum combination electrode (Fisher Scientific) referenced versus $\mathrm{Ag}-\mathrm{AgCl}$. The procedure is described as follows:

- For each experiment, $600 \mathrm{~mL}$ of feed solution was added to the reactor equipped with overhead stirrer impeller. To provide good suspension of the manganese powder in the test solution, 710-RPM speed of overhead stirrer (Cole Parmer) was provided throughout the test.

- The reactor was covered with the HDPE lid. The tubes on the reactor were then connected with the tap water in order to control the temperature. The ORP probe and $\mathrm{pH}$ probe were also inserted into the solution.

- The test solution in the reactor was purged with nitrogen gas to desorb any oxygen in the reactor.

- After the temperature reached $13{ }^{\circ} \mathrm{C}$, the manganese powder was added. Solution sampling was performed using $60 \mathrm{~mL}$ capacity syringes with $0.2 \mu \mathrm{m}$ membrane filter at 
intervals of $6,10,15,30,45$, and 60 minutes. The ORP values and acid consumptions were also recorded.

- At the conclusion of each test, the solution was filtered to separate residues and leachates. The filter cake was rinsed twice with water, then with alcohol, and finally dried at room temperature and weighed.

- Once the tests were complete, feed solution and samples solutions were determined by using Inductively Couple Plasma Mass Spectrometry (ICP-MS) by 5N PLUS.

A photograph of the experimental equipment used for the cementation tests is illustrated in Figure 4.2. The schematic diagram of the experimental setup is shown in Figure 4.3.

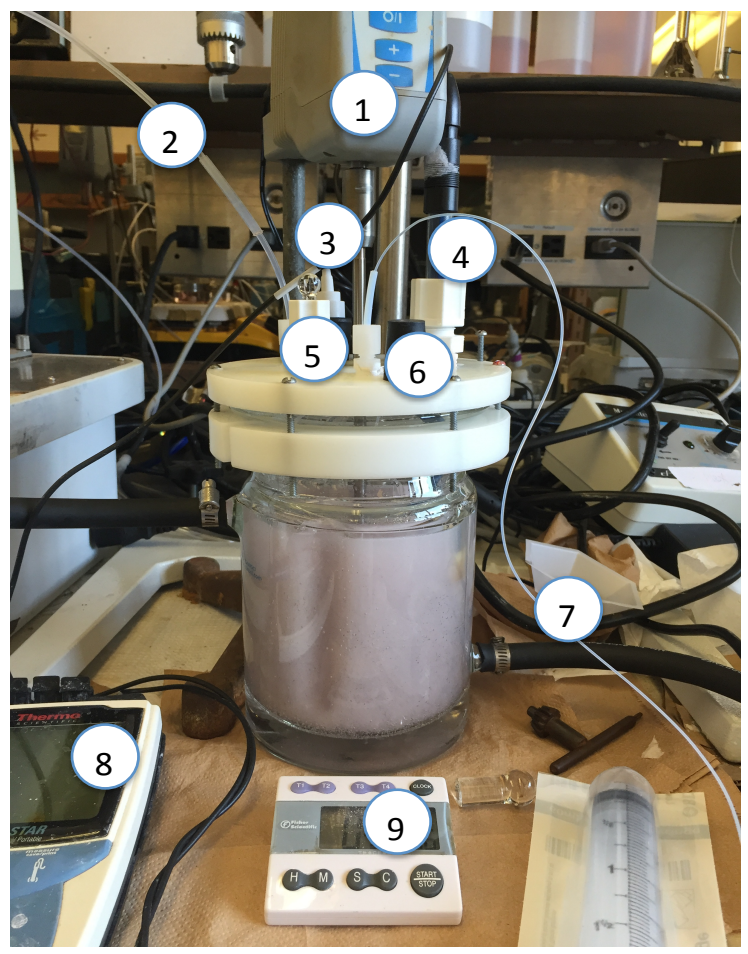

Figure 4.2 Experimental apparatus for cementation tests

(1-Stirring Rod, 2-Nitrogen Gas Inlet, 3-pH probe, 4-ORP probe, 5-Syringe port, 6-Mn Powder Port, 7-HCl Inlet, 8ORP Meter, 9-Timer) 


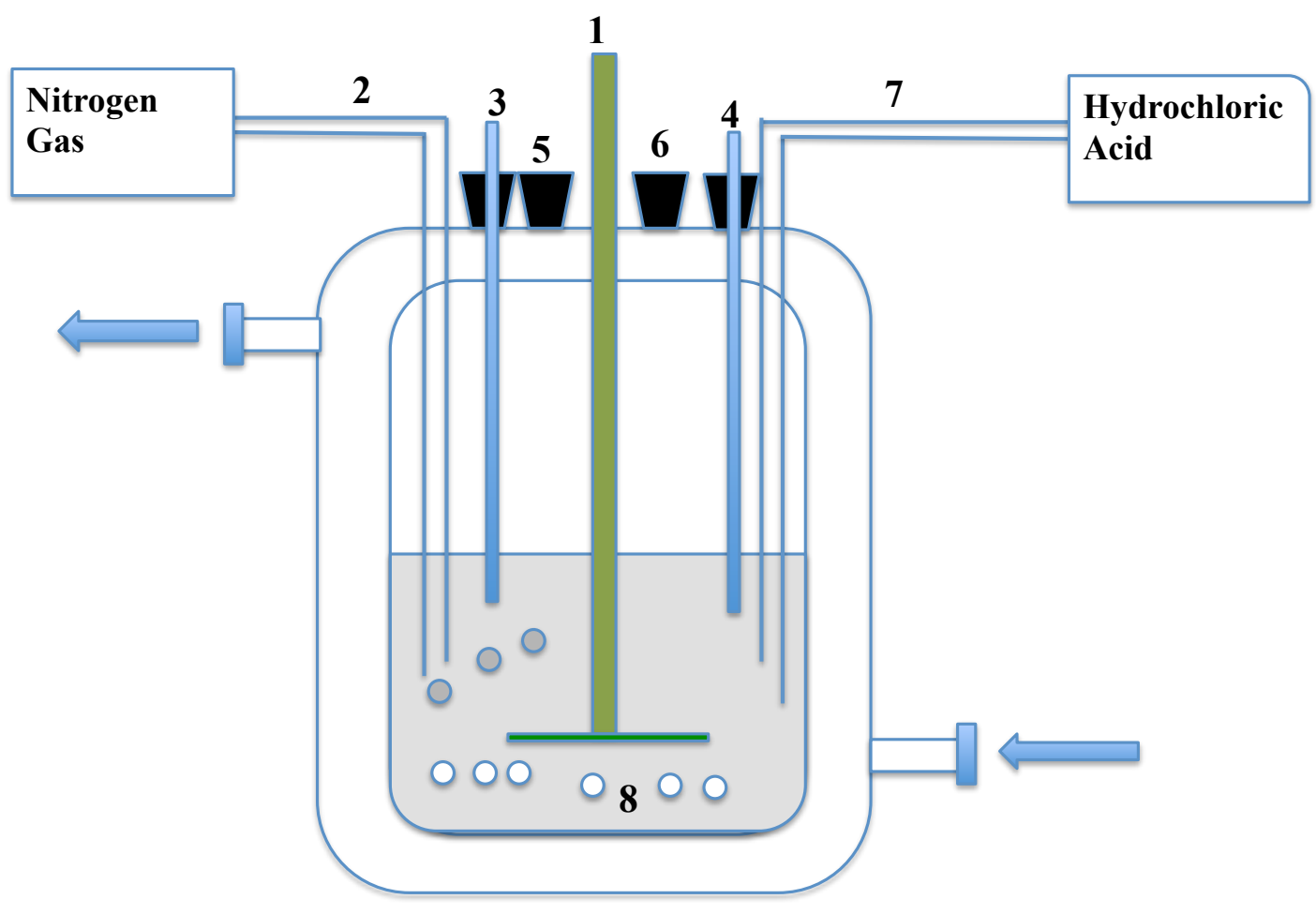

Figure 4.3 Schematic Diagram of Experimental Setup

(1-Stirring Rod, 2-Nitrogen Gas Inlet, 3-pH probe, 4-ORP probe, 5-Syringe port, 6-Mn Powder Port, 7-HCl Inlet, 8Excess $\mathrm{Mn}$ )

Table 4.2 Selected standard reduction potentials in aqueous solutions at $25^{\circ} \mathrm{C}[10]$

\begin{tabular}{|c|c|}
\hline Reaction & Standard reduction potential (v) \\
\hline $\mathrm{Mn}^{2+}+2 \mathrm{e}^{-}=\mathrm{Mn}$ & -1.18 \\
\hline $\mathrm{Cd}^{2+}+2 \mathrm{e}^{-}=\mathrm{Cd}$ & -0.4 \\
\hline $\mathrm{Co}^{2+}+2 \mathrm{e}^{-}=\mathrm{Co}$ & -0.28 \\
\hline $\mathrm{Ni}^{2+}+2 \mathrm{e}^{-}=\mathrm{Ni}$ & -0.23 \\
\hline $\mathrm{Zn}^{2+}+2 \mathrm{e}^{-}=\mathrm{Zn}$ & -0.76 \\
\hline $\mathrm{Cu}^{2+}+2 \mathrm{e}^{-}=\mathrm{Cu}$ & 0.34 \\
\hline $\mathrm{Cr}^{3+}+\mathrm{e}^{-}=\mathrm{Cr}$ & -0.41 \\
\hline $\mathrm{Cr}^{2+}+2 \mathrm{e}^{-}=\mathrm{Cr}$ & -0.91 \\
\hline
\end{tabular}




\subsubsection{Effect of $\mathrm{pH}$}

This series of experiments examined the effects of $\mathrm{pH}$ on cementation. $\mathrm{pH}$ levels were controlled with a $\mathrm{pH}$ controller and the solutions were adjusted to a desired $\mathrm{pH}$ value by the addition of hydrochloric acid. This is different from previous experiments that allowed $\mathrm{pH}$ levels to increase naturally during the course of the experimental run.

The cementation conditions are described in Table 4.3. Figure 4.4 and Figure 4.5 summarize the results from these experiments.

Table 4.3 Cementation conditions

\begin{tabular}{|c|c|}
\hline Solid & $6 \mathrm{~g}$ Manganese powder, $<10$ micron \\
\hline Rotation speed & $710 \mathrm{rpm}$ \\
\hline Atmosphere & Nitrogen atmosphere \\
\hline $\begin{array}{l}\text { Composition of solutions } \\
\text { in the reactor }\end{array}$ & $\begin{array}{l}\text { 2.0 M Manganese chloride +2.0 M Ammonium chloride } \\
\text { solution }+200 \text { ppb impurities }\end{array}$ \\
\hline $\mathrm{pH}$ & $5.0 / 5.5$ \\
\hline Temperature & $13^{\circ} \mathrm{C}$ \\
\hline Reaction time & $6,10,15,30,45,60$ minutes \\
\hline
\end{tabular}




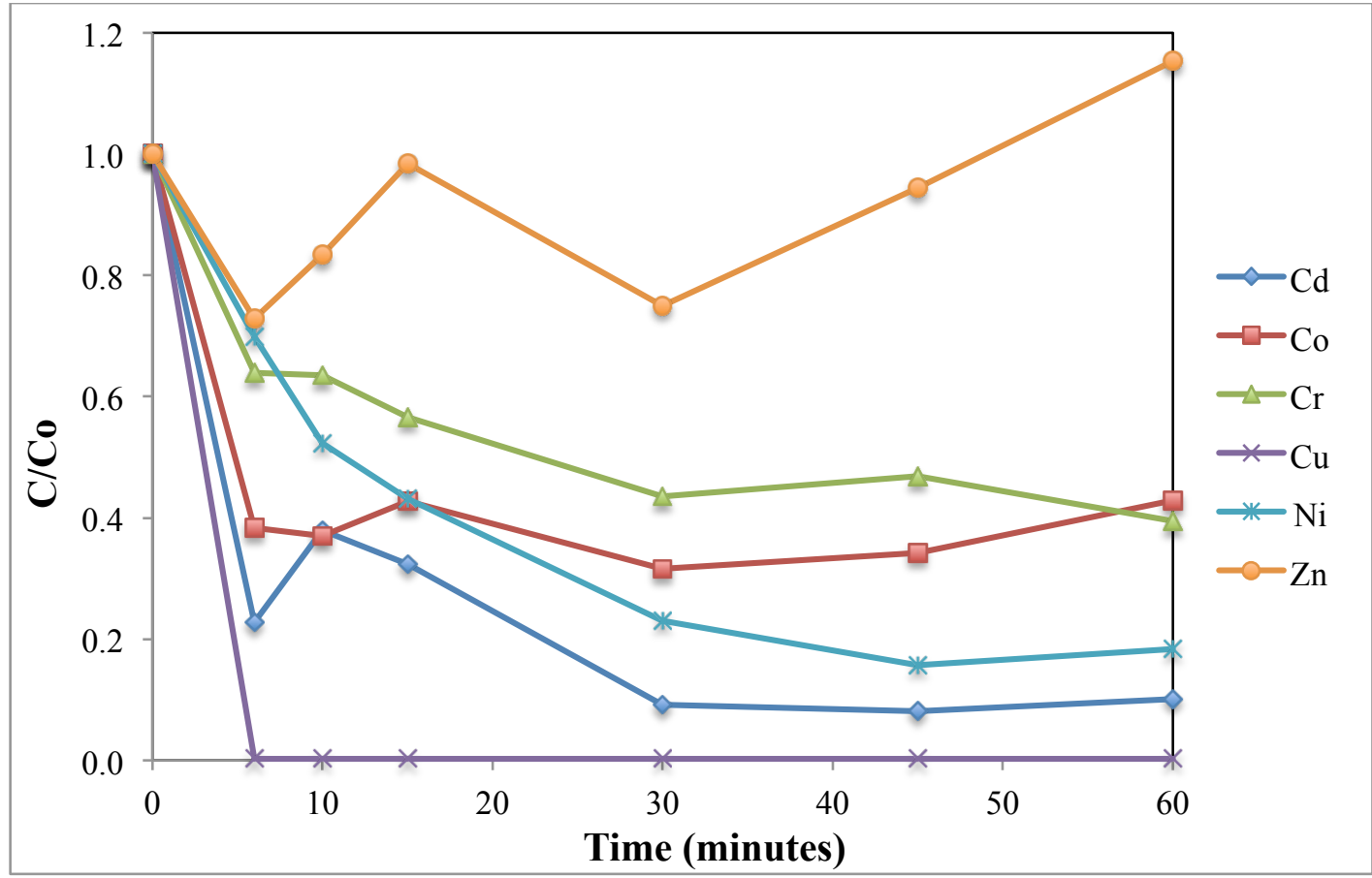

Figure 4.4 Impurities removal versus time at pH 5.5

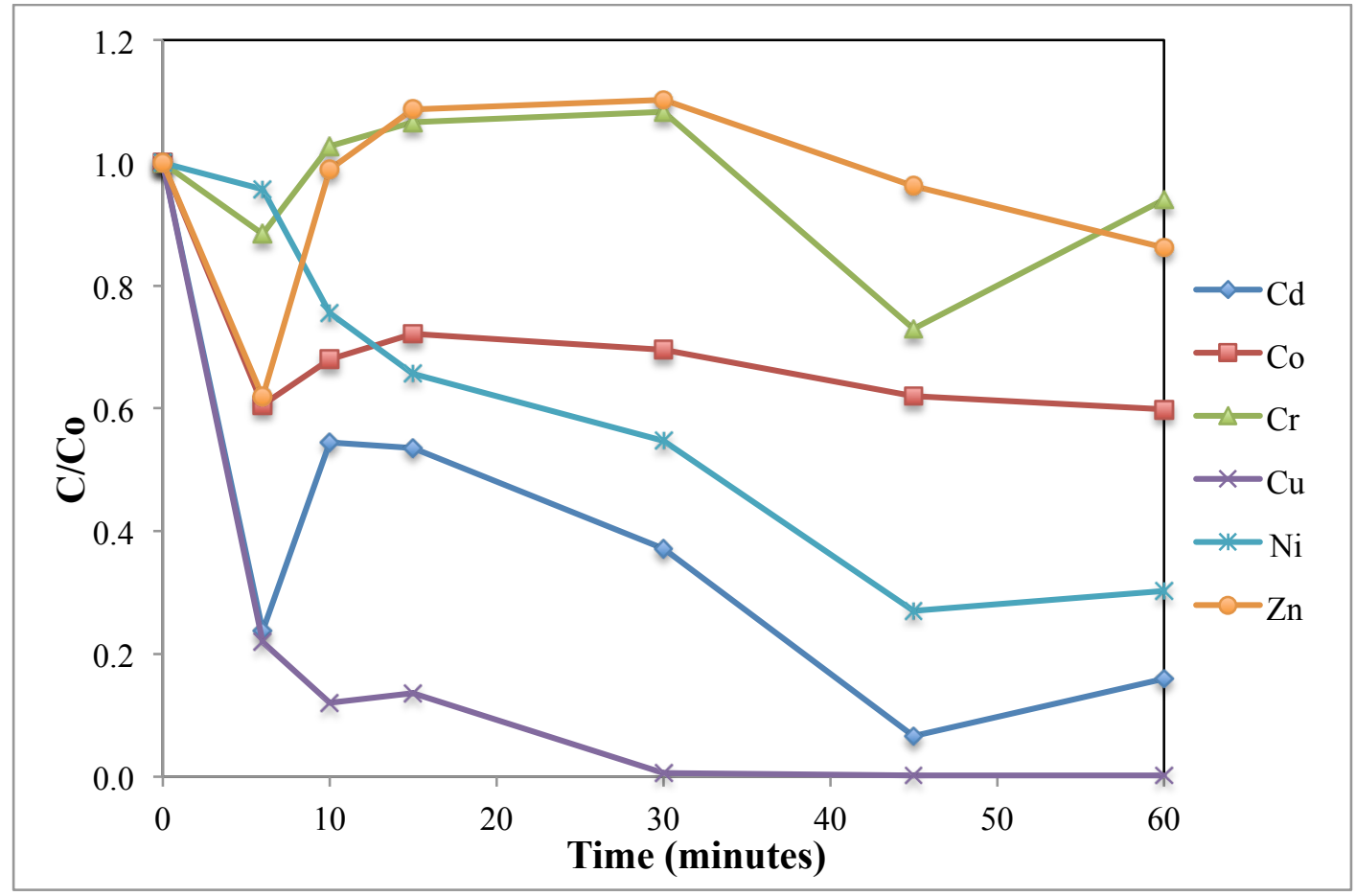

Figure 4.5 Impurities removal versus time at pH 5.0 
From Figure 4.4 and Figure 4.5, it was found that $\mathrm{Cu}^{2+}$ was completely removed from the solution and the concentration was below their detection limits. The removal of $\mathrm{Zn}^{2+}$ was limited during the reaction time due to the close value of the zinc and manganese reduction potentials. The ions of $\mathrm{Cd}^{2+}, \mathrm{Ni}^{2+}, \mathrm{Co}^{2+}$ and $\mathrm{Cr}^{3+}$ were partly eliminated. All the impurities removal rates were higher at $\mathrm{pH}$ 5.5. From the curves at $\mathrm{pH} 5.5$ and $\mathrm{pH} 5.0$, the descending order of selectivity on the manganese powder was: $\mathrm{Cu}>\mathrm{Cd}>\mathrm{Ni}>\mathrm{Co}>\mathrm{Cr}>\mathrm{Zn}$. It was found that the removal rates for some impurities were higher at the beginning. This is reasonable as the manganese powder was added into the solution at the beginning. Some impurities were re-dissolved at 60 minutes. So the reaction time was better to control at 30 45 minutes for a higher removal rate. From Figure 4.6, the slurry potential remained relatively stable at around $-620 \mathrm{mV}$ (vs. $\mathrm{Ag} / \mathrm{AgCl}$ ) throughout the experiment. Slurry potential at pH 5.5 was more negative, correlated to the higher removal rate. However, from Figure 4.4 and 4.5, it was found that there were still plenty of impurities in the solutions. So the cementation by manganese powder was not suitable for the total purification requirements to electrorefine high purity manganese. 


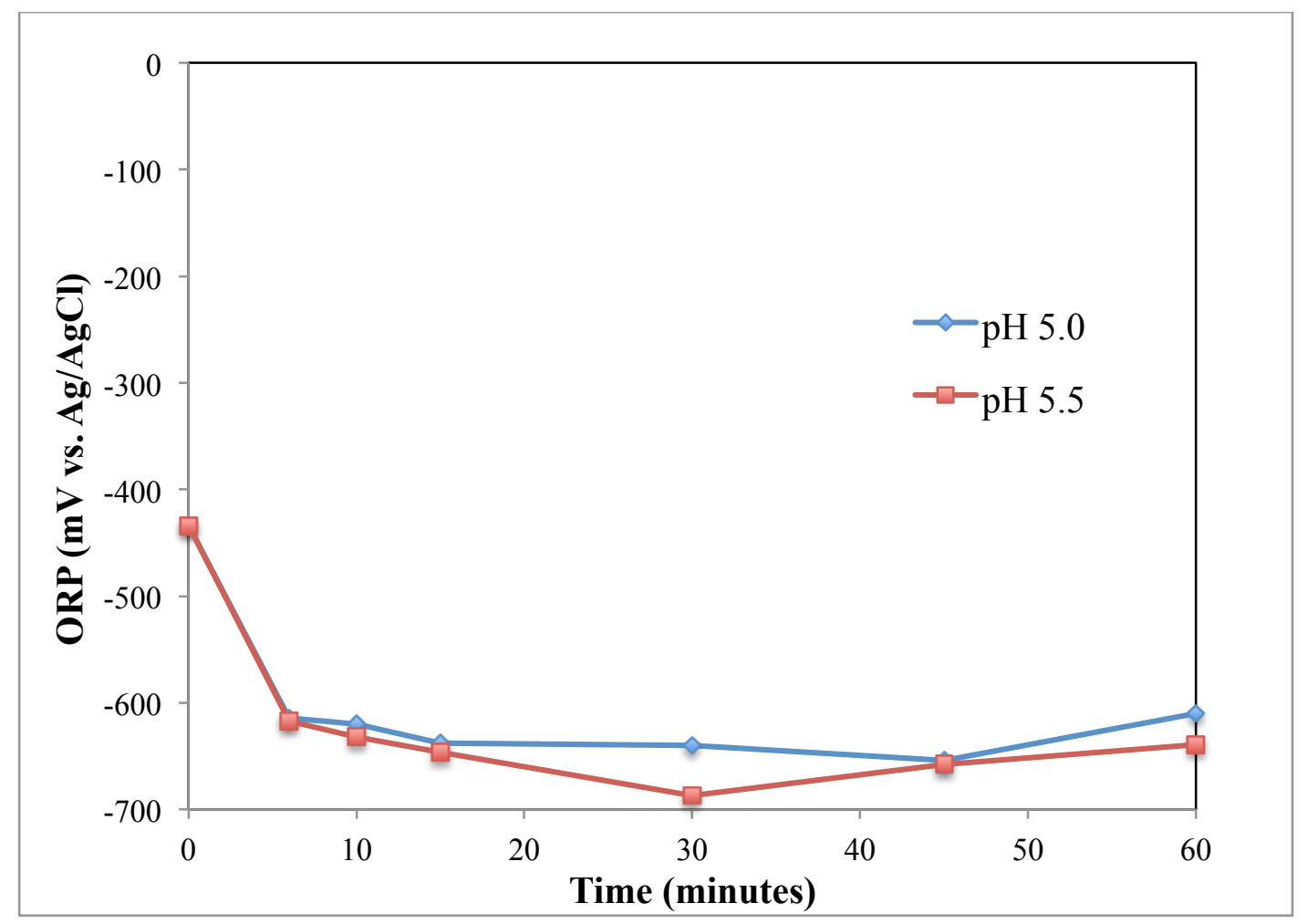

Figure 4.6 pH effects on slurry potential

\subsection{Equilibrium Ion Exchange Studies}

The sorption of metals was studied by the batch technique. Adsorption tests were carried out at room temperature in a $250-\mathrm{mL}$ baffle reactor by mixing the solution with resins under sufficient agitation for 20 hours to reach equilibrium. The procedure is described as follows:

- For each experiment, $150 \mathrm{~mL}$ of feed solution was added to the test vessel equipped with overhead stirrer impeller. To provide good suspension of the resin in the test solution, 250-RPM speed of overhead stirrer (Cole Parmer) was provided throughout the test.

- Metal ions impurities $\left(\mathrm{Cu}^{2+}, \mathrm{Ni}^{2+}, \mathrm{Cd}^{2+}, \mathrm{Zn}^{2+}\right.$, and $\left.\mathrm{Co}^{2+}\right)$ were then added to the test solution at a concentration of $100 \mathrm{ppb}$ at each impurity. 
- A pH probe with temperature compensation was calibrated using $\mathrm{pH}$ buffers 7 and 4 . The test solution was adjusted to different $\mathrm{pH}$ values by adding dilute hydrochloric acid or ammonium hydroxide drops.

- Each test was deemed complete when the $\mathrm{pH}$ remained constant at the final set point for at least $4 \mathrm{~h}$. The majority of final $\mathrm{pH}$ values were within $\pm 0.05 \mathrm{pH}$ units from the target set point, and all were within $\pm 0.1 \mathrm{pH}$ units.

- After equilibrium was reached, the resin was separated from the solution by vacuum filtration and washed with de-ionized water. Once the tests were complete, samples of the feed solution and final solution were analyzed using Inductively Couple Plasma Mass Spectrometry (ICP-MS) by $5 \mathrm{~N}$ PLUS. For the manganese (II) concentration, the potentiometric titration of manganous ion with permanganate ion in pyrophosphate solution was used (See Section 4.3).

A photograph of the experimental equipment used for the batch tests is illustrated in Figure 4.7. 


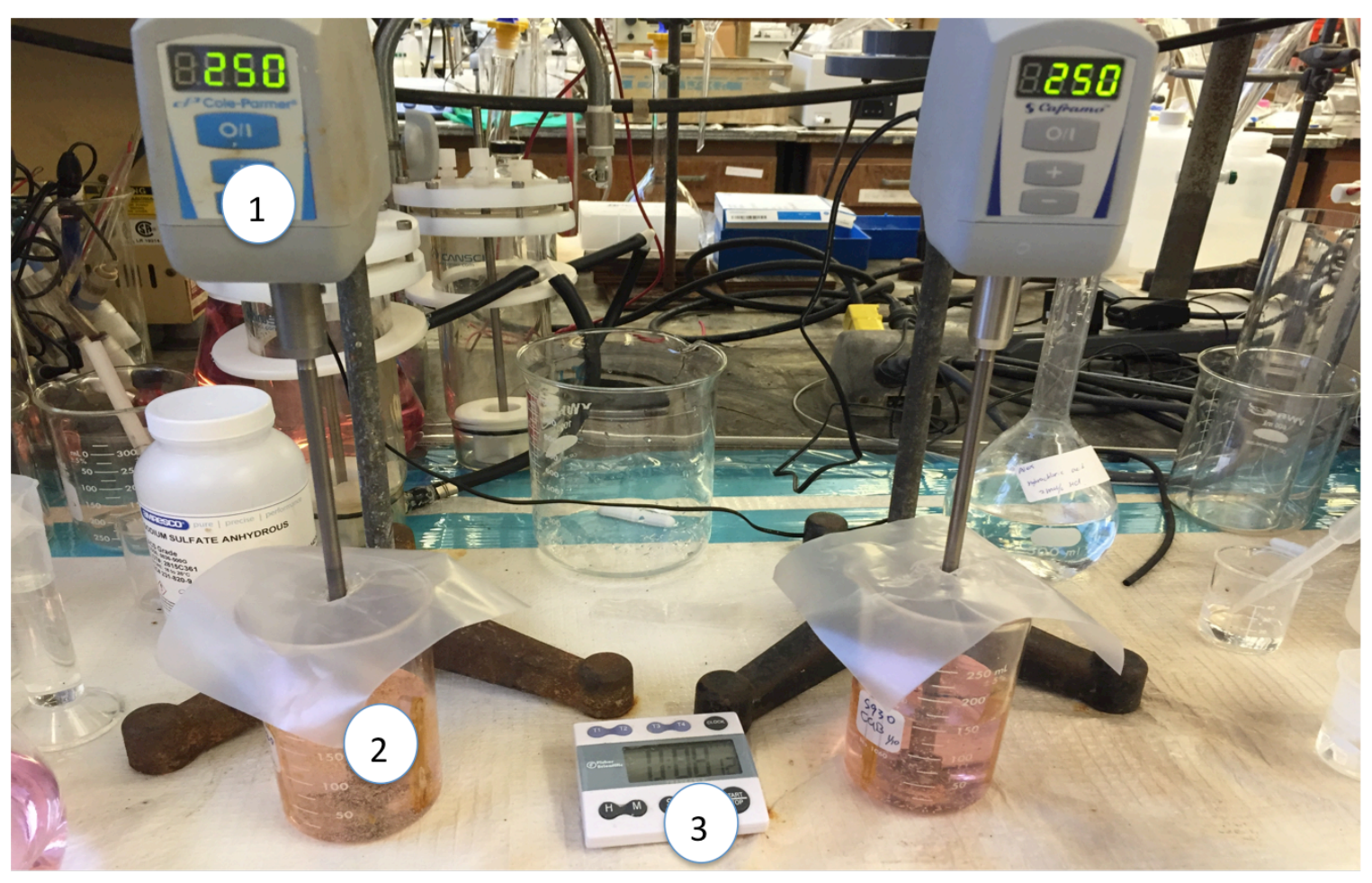

Figure 4.7 Batch Loading Study Experimental Equipment

(1-Overhead stirrer, 2-Test vessel, 3-Timer)

\subsubsection{Effect of $\mathrm{pH}$}

A series of equilibrium loading experiments was performed on each resin, using the procedure described in Section 4.5. $150 \mathrm{ml}$ synthetic electrolyte feed solutions with different $\mathrm{pH}$ values were used to study the effect of the solution $\mathrm{pH}$. The resin dosage was fixed at $0.1 \mathrm{~g}$. The tests were completed after about 20 hours, which typically provided adequate time for the ion exchange reaction to reach equilibrium. After equilibration, resin and test solution were separated by filtration. The experimental conditions for the $\mathrm{pH}$ effect studies are shown in Table 4.4. Table 4.5 shows the effect of equilibrium $\mathrm{pH}$ on the percentage of metal adsorbed by Lewatit ${ }^{\circledR}$ MDS TP220 and Purolite S930Plus from metal solutions. 
Table 4.4 Experimental conditions for the pH effect studies

\begin{tabular}{|l|c|}
\hline Resin type & TP220, S930Plus \\
\hline Resin dosage & $0.1 \mathrm{~g}$ \\
\hline Rotation speed & $250 \mathrm{RPM}$ \\
\hline Composition of solutions & Room temperature \\
\hline Temperature & 20 hours \\
\hline Reaction time & $5 / 5.0 / 5.5$ \\
\hline $\mathrm{pH}$ & $\mathrm{M} \mathrm{MnCl}_{2}+2.0 \mathrm{M} \mathrm{NH}_{4} \mathrm{Cl}+100 \mathrm{pp}$ impurities \\
\hline
\end{tabular}

Table 4.5 Removal rates of metals with various resins, $\%$

\begin{tabular}{cccccccc}
\hline Resin & $\mathrm{pH}$ & $\mathrm{Cd}$ & $\mathrm{Co}$ & $\mathrm{Cu}$ & $\mathrm{Ni}$ & $\mathrm{Zn}$ & $\mathrm{Mn}$ \\
\hline TP220 & 4.50 & 40.93 & 91.89 & 87.90 & 84.02 & 68.15 & 0.43 \\
TP220 & 5.00 & 39.75 & 89.93 & 82.92 & 80.34 & 73.89 & 0.34 \\
TP220 & 5.50 & 23.33 & 83.26 & 84.38 & 80.60 & 82.17 & 0.38 \\
S930Plus & 4.50 & $<0$ & 15.55 & 81.89 & 6.87 & $<0$ & 0.26 \\
S930Plus & 5.00 & $<0$ & 42.30 & 91.07 & 38.27 & $<0$ & 0.23 \\
S930Plus & 5.50 & $<0$ & 29.91 & 78.28 & 23.20 & $<0$ & 0.30 \\
\hline
\end{tabular}

Note from the table that both of the resins had a higher removal rate when the $\mathrm{pH}$ of the solution was at 5. For the TP220, it could remove the most of $\mathrm{Cu}^{2+}, \mathrm{Ni}^{2+}, \mathrm{Co}^{2+}$ and $\mathrm{Zn}^{2+}$, and partly remove the $\mathrm{Cd}^{2+}$. For the S930Plus, it could remove the most of the $\mathrm{Cu}^{2+}$. But it had no effect to $\mathrm{Cd}^{2+}$ and $\mathrm{Zn}^{2+}$, and could remove a small amount of $\mathrm{Co}^{2+}$ and $\mathrm{Ni}^{2+}$. Removal rates of $\mathrm{Cd}^{2+}$ and $\mathrm{Zn}^{2+}$ are below 0 , probably due to the analytical error. It is unlikely that the resin was a source of metals entering solution.

\subsubsection{Effect of Resin Quantity}

The resin amount is also one of the important parameters to obtain the quantitative uptake of metal ion. The dependence of metal sorption on resin input amount was studied by varying the 
amount of resins $(0.05-0.3 \mathrm{~g})$, while the other parameters such as $\mathrm{pH}(\mathrm{pH}$ 5), initial metal concentration and stirring speed $(250 \mathrm{rpm})$ remained constant. The experimental conditions for the resin dosage effect studies are shown in Table 4.6. The amount of metal adsorbed per unit mass $\left(Q_{e}\right)$ was calculated as follows:

$$
Q_{e}=\frac{C-C_{0}}{m} V
$$

Equation 4.1

Where $\mathrm{C}$ and $\mathrm{C}_{0}$ are the initial and final concentrations $(\mu \mathrm{g} / \mathrm{L}), \mathrm{m}$ is the mass of resins $(\mathrm{g})$, and V is the volume of the metal containing solutions (L).

It was apparent that the adsorption percentage of metal ions increased with higher resin dosages (Figure 4.8 and Figure 4.9). This result proved that increasing the amount of resin provides higher removal due to provision of a greater number of adsorption sites. The resin dosage effects on the resin capacities $\left(\mathrm{Q}_{\mathrm{e}}\right)$ were shown in Figure 4.10 and Figure 4.11.

Table 4.6 Experimental conditions for the resin dosage effect studies

\begin{tabular}{|l|c|}
\hline Resin type & TP220, S930Plus \\
\hline Resin dosage & $0.05 / 0.1 / 0.15 / 0.20 / 0.25 / 0.30 \mathrm{~g}$ \\
\hline Rotation speed & $250 \mathrm{RPM}$ \\
\hline Composition of solutions & $2.0 \mathrm{M} \mathrm{MnCl}_{2}+2.0 \mathrm{M} \mathrm{NH} \mathrm{Cl}^{+}+100 \mathrm{ppb}$ impurities \\
\hline Temperature & Room temperature \\
\hline Reaction time & 20 hours \\
\hline $\mathrm{pH}$ & 5 \\
\hline
\end{tabular}




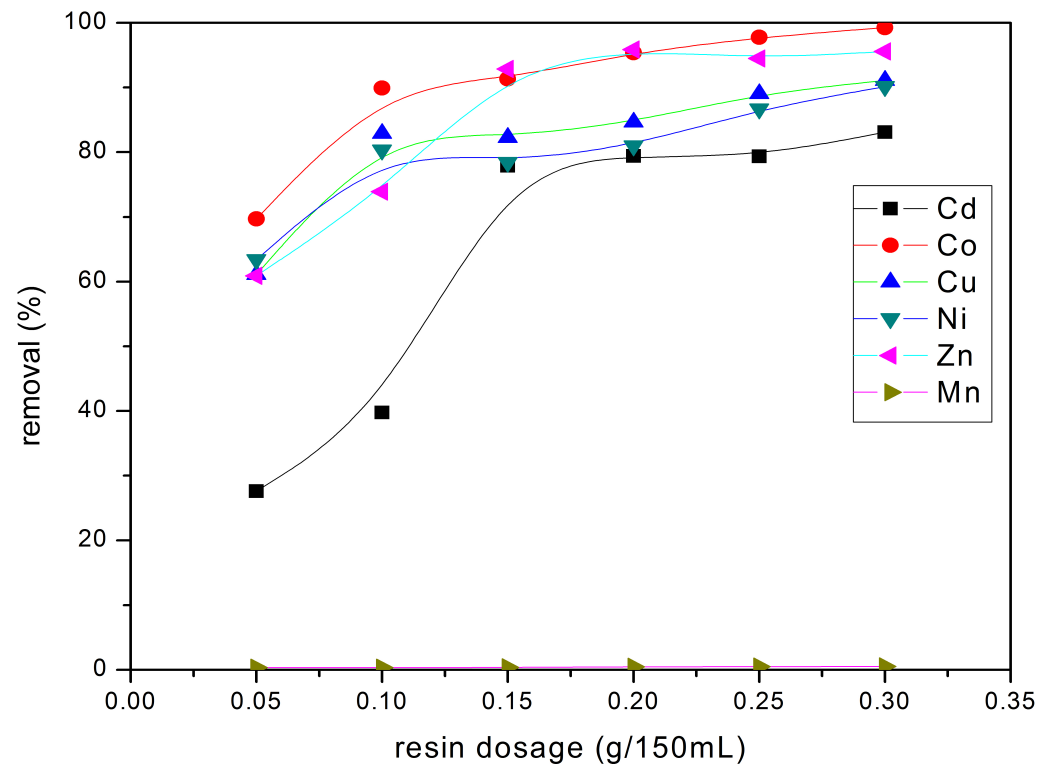

Figure 4.8 Effect of resin dosage on removal of impurities by Lewatit ${ }^{\circledR}$ MDS TP220 resin $(p H$ 5, agitation period $20 \mathrm{~h}$ )

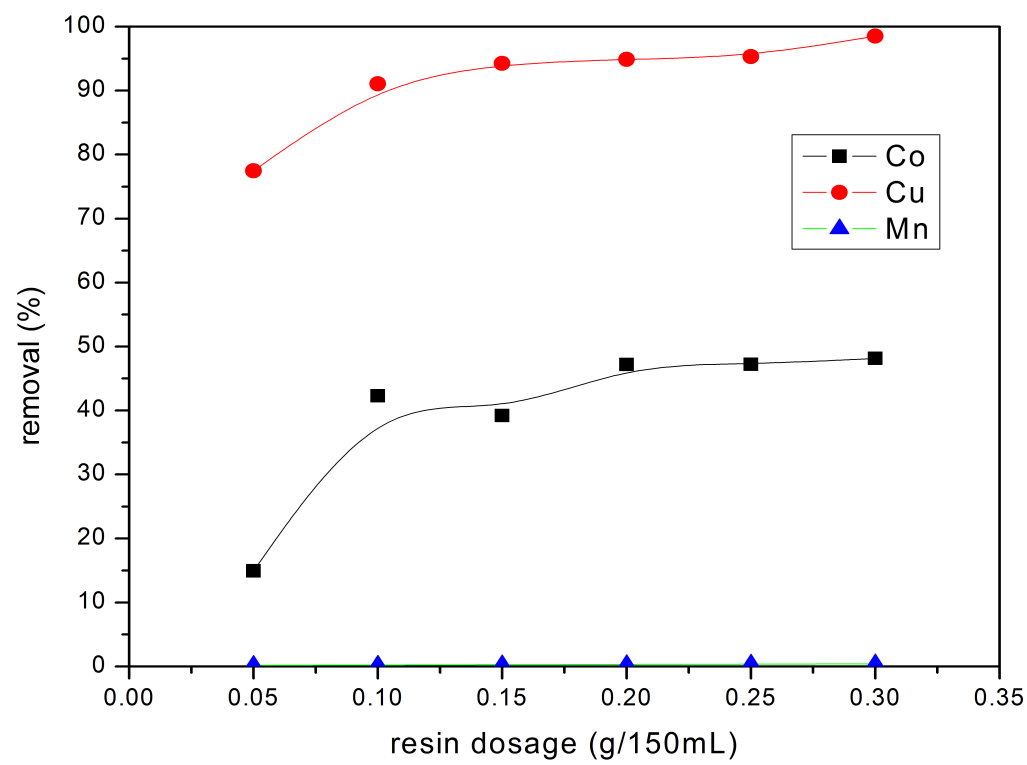

Figure 4.9 Effect of resin dosage on removal of impurities by Purolite S930Plus resin ( $p H$ 5, agitation period $20 \mathrm{~h})$ 


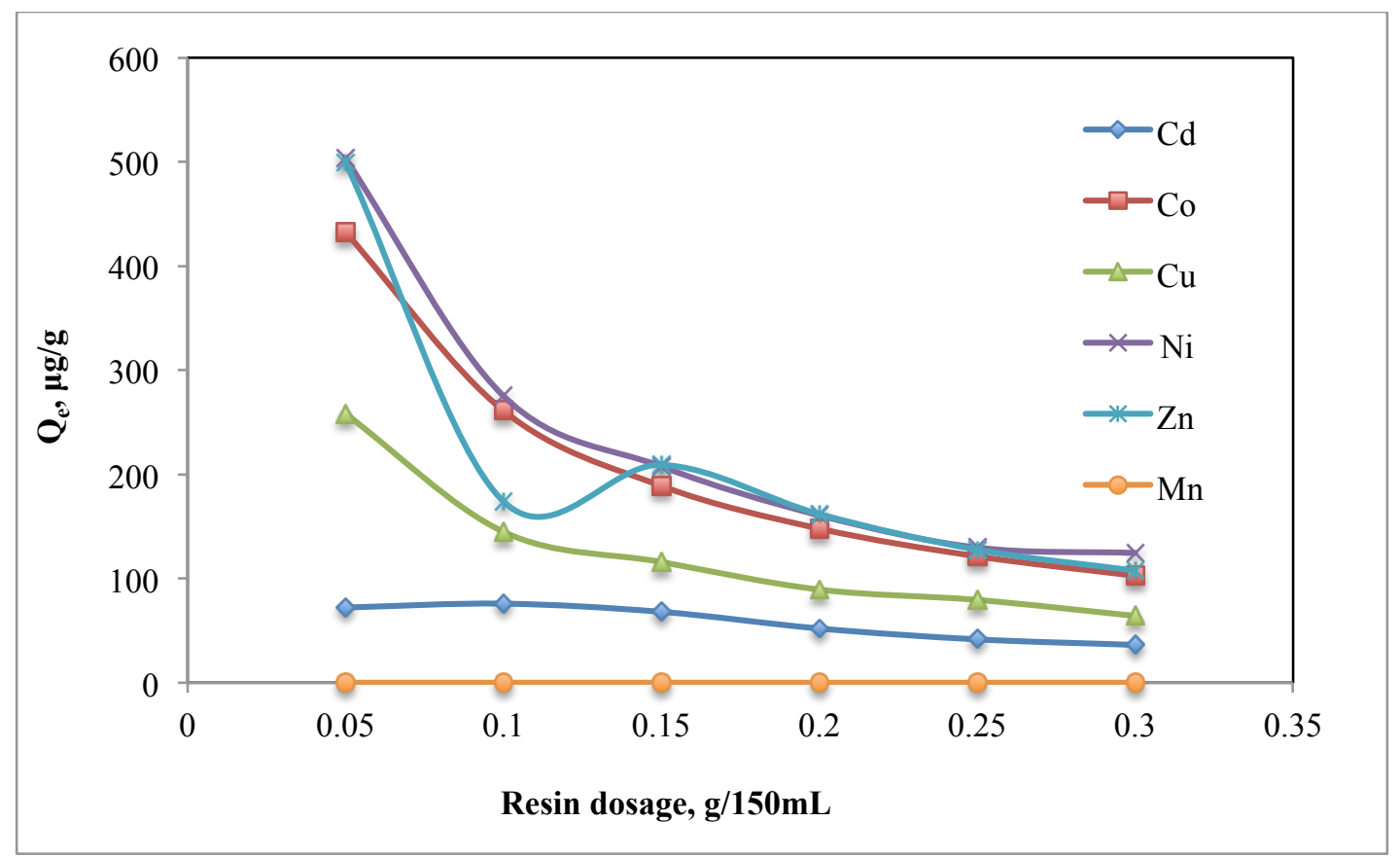

Figure 4.10 Lewatit ${ }^{\circledR}$ MDS TP220 resin dosage effect on the metal ions adsorption (pH 5, agitation period 20

h)

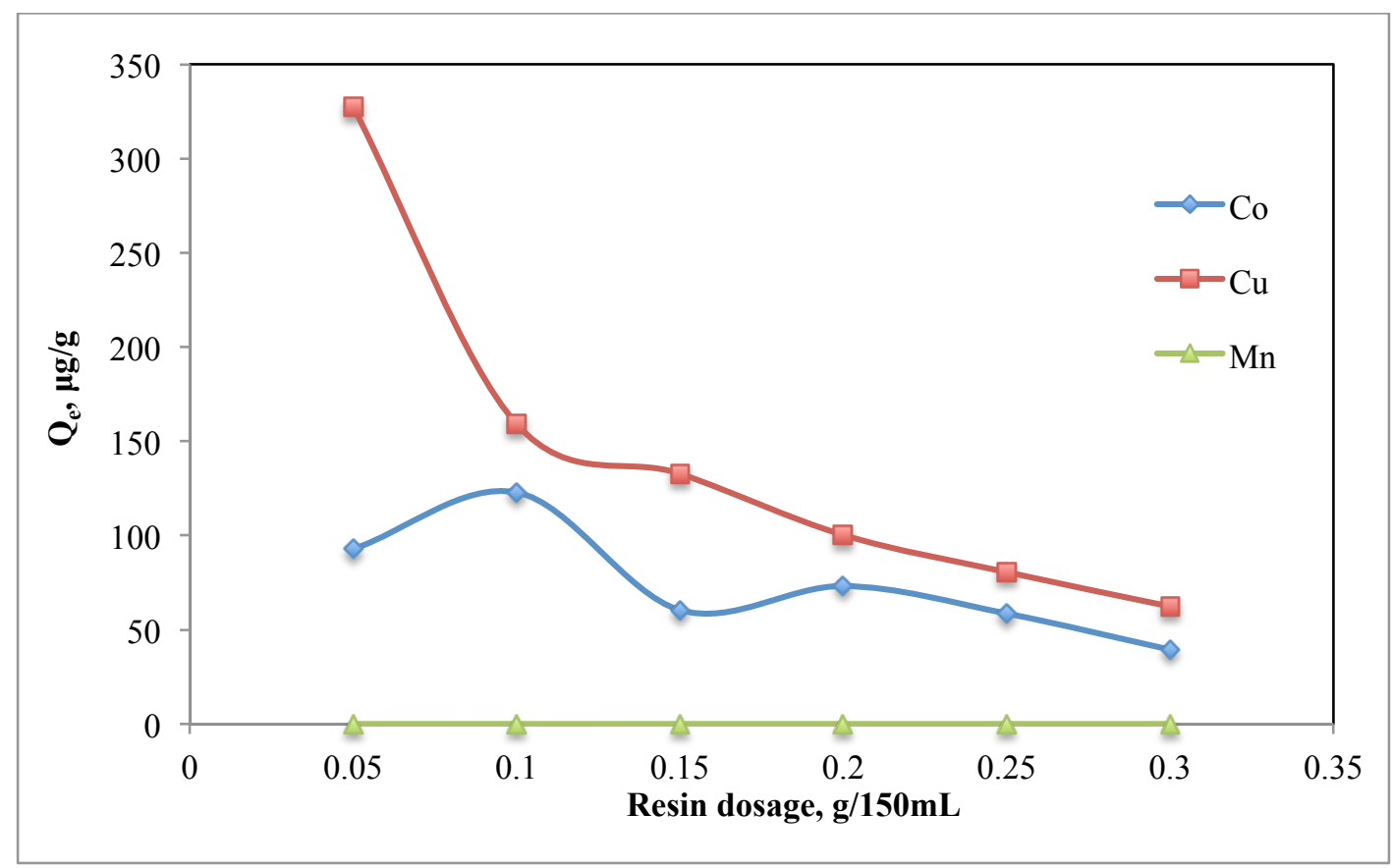

Figure 4.11 Purolite S930Plus resin dosage effect on the metal ions adsorption ( $\mathrm{pH}$ 5, agitation period $20 \mathrm{~h}$ ) 
Figure 4.8 suggests that TP220 resin had a strong selectivity for $\mathrm{Cu}^{2+}, \mathrm{Ni}^{2+}, \mathrm{Cd}^{2+}, \mathrm{Zn}^{2+}$, and $\mathrm{Co}^{2+}$, and it had no effect to $\mathrm{Mn}^{2+}$. For $\mathrm{Cd}^{2+}$, the removal rate was low when the resin dosage was at $0.05 \mathrm{~g}$. It increased significantly when the resin dosage reached $0.15 \mathrm{~g}$. From figure 4.9 , the apparent sequence of affinity of metals was $\mathrm{Cu}>\mathrm{Co}>\mathrm{Mn}$ for the Purolite S930Plus resin. The curve clearly demonstrated the strong selectivity of the resin for copper over the other metals present in the solution. From Figure 4.8 and Figure 4.9, it was found that when the resin dosages were above $0.15 \mathrm{~g}$, the removal rates increased slightly. As shown in Figure 4.10 and Figure 4.11, it is clear that by increasing the resin dosage from 0.05 to $0.3 \mathrm{~g}$, the sorption capacity, the amount of metallic ions adsorbed per unit mass decreases while the removal percentage of ions increases. This is because by increasing the resin dosage the number of available adsorption binding sites increases so as to increase the removal extent[79]. On the other hand, the decrease in resin sorption capacity with an increase in the resin dosage is reported to be due to the unsaturation of adsorption sites during the adsorption process[80]. The decrease in the number of metal molecules available for each active site with an increase in the amount of resin results in a reduction in the concentration gradient between the bulk of the solution and the surface of the resin.

\subsection{Column Studies}

A synthetic loading electrolyte solution at $\mathrm{pH} 5$ was prepared, and the resulting solution had a typical composition of $150 \mu \mathrm{g} / \mathrm{L} \mathrm{Cd}, 230 \mu \mathrm{g} / \mathrm{L} \mathrm{Cu}, 391 \mu \mathrm{g} / \mathrm{L} \mathrm{Ni}, 300 \mu \mathrm{g} / \mathrm{L} \mathrm{Co}, 344 \mu \mathrm{g} / \mathrm{L}$ Zn, and $110 \mathrm{~g} / \mathrm{L} \mathrm{Mn}$. The procedure is described as follows: 
- For each experiment, resin was placed in a Plexiglas column, $400 \mathrm{~mm}$ long, and $8 \mathrm{~mm}$ in diameter, with a bed height of $150 \mathrm{~mm}$. The resin was rinsed with $2 \mathrm{~mol} / \mathrm{L} \mathrm{HCl}$ solution and deionized water before separation tests in order to remove organic and inorganic contamination during the manufacturing process.

- The loading solution was pumped at a flow rate of approximately $1 \mathrm{~mL} / \mathrm{min}$ down through the ion exchange resin, with a Masterflex \#14 L/S peristaltic pump.

- $\mathrm{A} \mathrm{pH}$ probe with temperature compensation was calibrated using $\mathrm{pH}$ buffers 7 and 4 . The test solution was adjusted to 5 by adding dilute hydrochloric acid or ammonium hydroxide drops.

- The treated solution was collected from the outlet of the column at different time intervals and analyzed by Inductively Couple Plasma Mass Spectrometry (ICP-MS) by $5 \mathrm{~N}$ PLUS. For the manganese (II) concentration, the potentiometric titration of manganous ion with permanganate ion in pyrophosphate solution was used.

A photograph of the experimental equipment used for the batch tests is illustrated in Figure 4.12. 


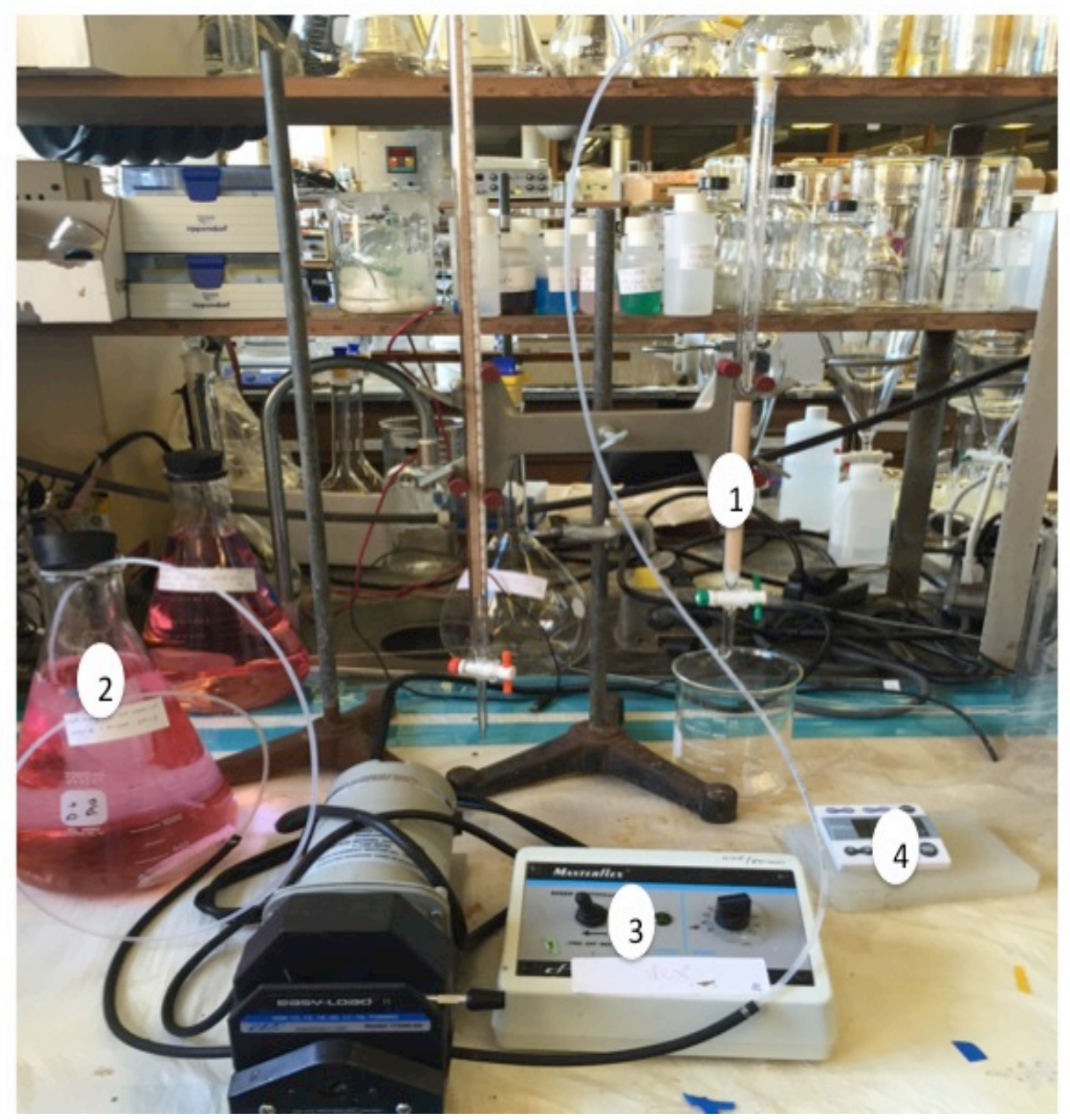

Figure 4.12 Column Loading Study Experimental Equipment

(1-Test Column, 2-Test solution, 3-Peristaltic pump, 4-Timer)

\subsubsection{Effect of Resin Quantity}

The breakthrough curves for metal ions sorption on Lewatit ${ }^{\circledR}$ MDS TP220 and Purolite S930Plus resin were recorded for various resin quantities ranged between 1 and $3 \mathrm{~g}$ (various bed heights, from 6 to $18 \mathrm{~cm})$, at a flow rate of $1 \mathrm{~mL} / \mathrm{min}(\mathrm{pH}=5)$. The obtained results, based on the effluent concentration (C) at the sampling bed volume, are presented in Figure 4.13, Figure 
4.14 and Figure 4.15 for the Lewatit ${ }^{\circledR}$ MDS TP220 resin and Purolite S930Plus resin. The concentration of an element in the final solution (C), divided by the concentration of that element in the initial solution $\left(\mathrm{C}_{0}\right)$ is plotted against the bed volume. $\mathrm{A} C / \mathrm{C}_{0}$ value equal to one would indicate that there is no interaction of the element with the resin. If an element loads onto the resin, then the $\mathrm{C} / \mathrm{C}_{0}$ value would be less than one. Similarly, if an element was displaced from the resin, then the $\mathrm{C} / \mathrm{C}_{0}$ value would be greater than unity. Therefore, a resin is considered to have a higher selectivity for elements that appear lower on the table (i.e. lower $\mathrm{C} / \mathrm{C}_{0}$ values). The experimental conditions for the resin quantities effect column studies are shown in Table 4.7.

Table 4.7 Experimental conditions for the resin quantities effect column studies

\begin{tabular}{|l|c|}
\hline Resin type & TP220, S930Plus \\
\hline Resin quantity & $1 \mathrm{~g}$, and $3 \mathrm{~g}$ for TP220; $\mathrm{g}$ for S930Plus \\
\hline Flow rate & $1 \mathrm{~mL} / \mathrm{min}$ \\
\hline $\begin{array}{l}\text { Composition of } \\
\text { solutions }\end{array}$ & $2.0 \mathrm{M} \mathrm{MnCl}_{2}+2.0 \mathrm{M} \mathrm{NH}{ }_{4} \mathrm{Cl}+200 \mathrm{ppb}$ impurities \\
\hline Temperature & Room temperature \\
\hline Reaction time & $1 \mathrm{~g}$ TP220 for 24 hours, $3 \mathrm{~g}$ TP220 for 48 hours; $3 \mathrm{~g}$ S930Plus for 26 \\
$\mathrm{pH}$ & 5 \\
\hline
\end{tabular}




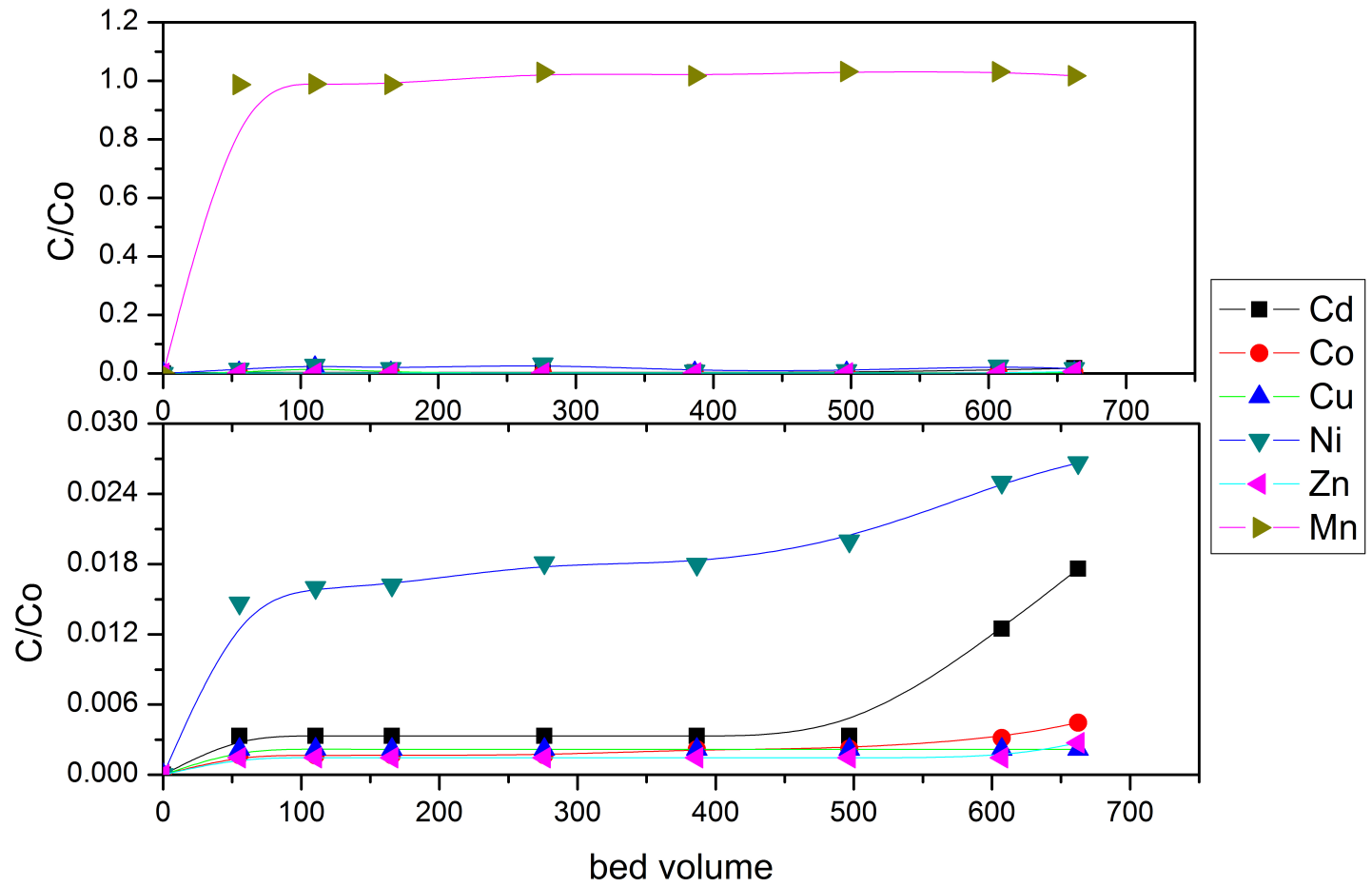

Figure 4.13 Breakthrough curves of $\mathrm{Cu}^{2+}, \mathrm{Ni}^{2+}, \mathrm{Cd}^{2+}, \mathrm{Zn}^{2+}, \mathrm{Co}^{2+}$ and $\mathrm{Mn}^{2+}$ from a flow-through column test with manganese chloride solution by 3 g TP220 resin

(Bed volume $=4.3 \mathrm{~mL}$; flow rate $=1 \mathrm{~mL} / \mathrm{min}(13.8 \mathrm{BV} / \mathrm{h}), \mathrm{TP220}$ resin quantity $3 \mathrm{~g}) . \mathrm{C}$ denotes the concentration of each metal in the final effluent, $C_{0}$ the concentration in the feed. 


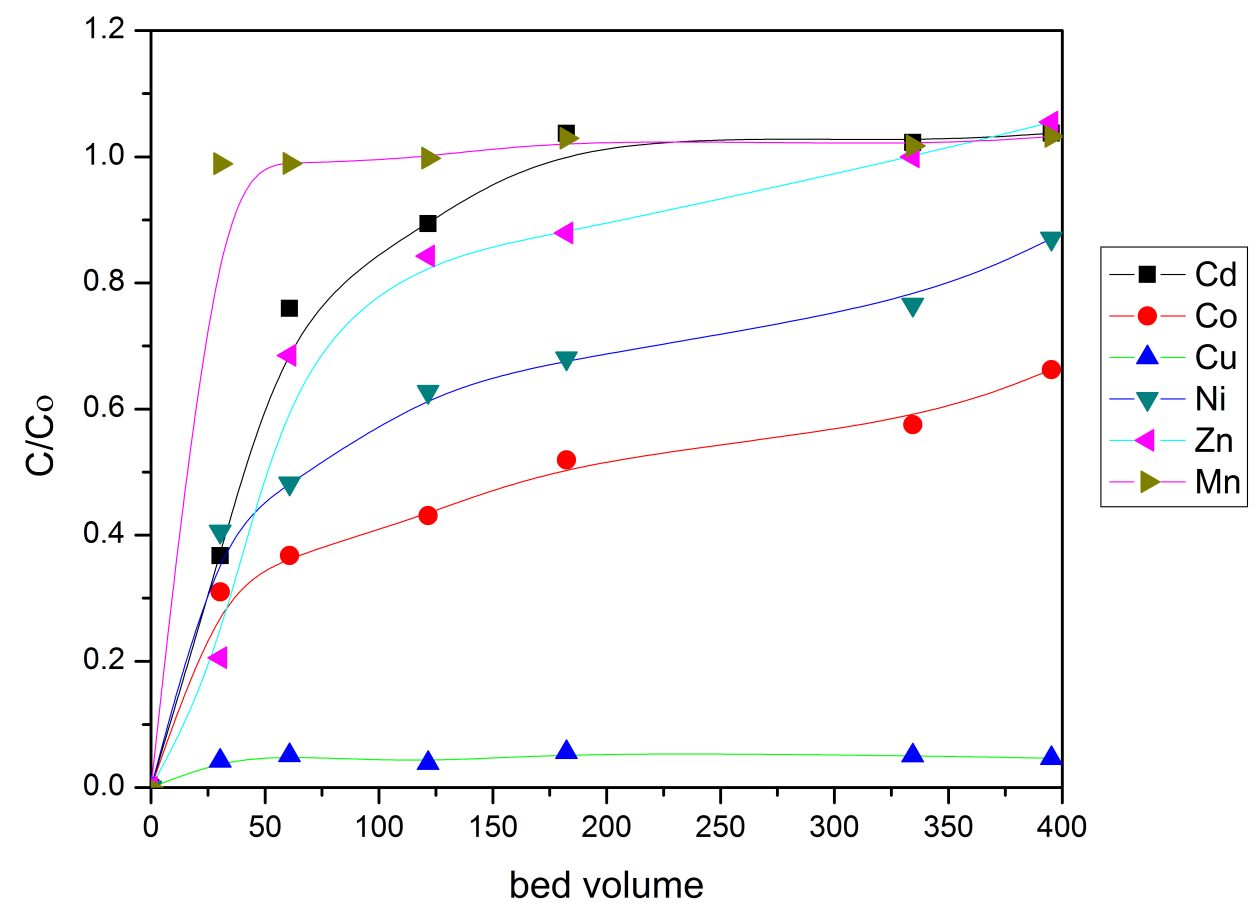

Figure 4.14 Breakthrough curves of $\mathrm{Cu}^{2+}, \mathrm{Ni}^{2+}, \mathrm{Cd}^{2+}, \mathrm{Zn}^{2+}, \mathrm{Co}^{2+}$ and $\mathrm{Mn}^{2+}$ from a flow-through column test with manganese chloride solution by 3 g S930Plus resin

(Bed volume $=3.95 \mathrm{~mL}$; flow rate $=1 \mathrm{~mL} / \mathrm{min}(15.2 \mathrm{BV} / \mathrm{h}), \mathrm{S930Plus}$ resin quantity $3 \mathrm{~g}) . \mathrm{C}$ denotes the concentration of each metal in the final effluent, $C_{0}$ the concentration in the feed. 


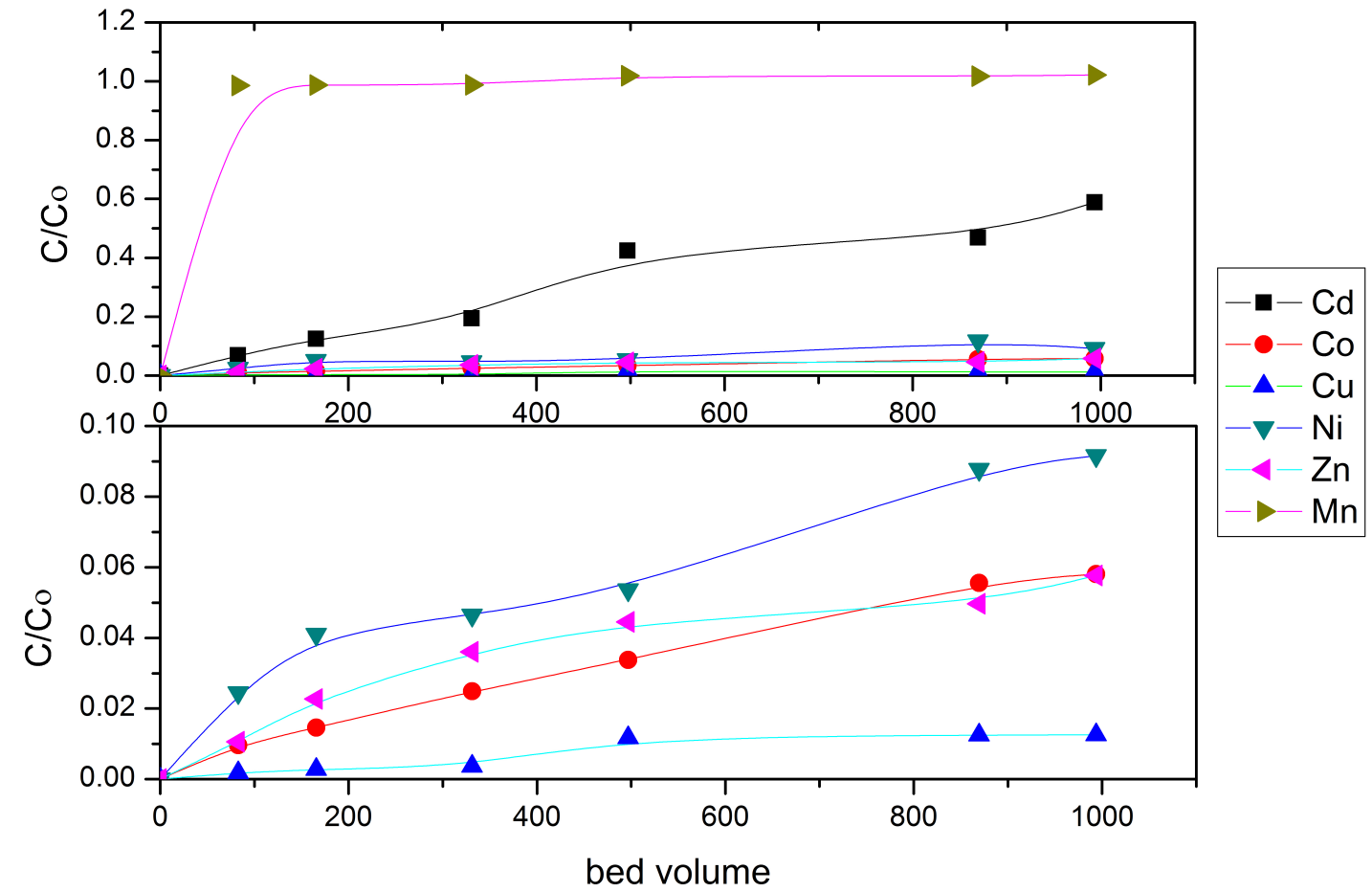

Figure 4.15 Breakthrough curves of $\mathrm{Cu}^{2+}, \mathrm{Ni}^{2+}, \mathrm{Cd}^{2+}, \mathrm{Zn}^{2+}, \mathrm{Co}^{2+}$ and $\mathrm{Mn}^{2+}$ from a flow-through column test with manganese chloride solution by $1 \mathrm{~g}$ TP220 resin

(Bed volume $=1.43 \mathrm{~mL}$; flow rate $=1 \mathrm{~mL} / \mathrm{min}(41.4 \mathrm{BV} / \mathrm{h})$, TP220 resin quantity $1 \mathrm{~g}) . \mathrm{C}$ denotes the concentration of each metal in the final effluent, $C_{0}$ the concentration in the feed.

For the column test, the flow rate was kept constant at $1 \mathrm{ml} / \mathrm{min}$. So the bed volume of the test would be different because of the resin quantity. From Figure 4.13, it was observed that the curves clearly demonstrated the strong selectivity of the resin for $\mathrm{Cu}^{2+}, \mathrm{Ni}^{2+}, \mathrm{Cd}^{2+}, \mathrm{Zn}^{2+}$ and $\mathrm{Co}^{2+}$ over the other metals present in the solution in these conditions; after $662 \mathrm{BV}$, these ions had still not broken through the column. Manganese broke through the column shortly after feed was supplied, due to its low affinity for the resin, and its high concentration in the feed. The 
concentration of manganese in the effluent reached that in the feed $\left(\mathrm{C} / \mathrm{C}_{0}=1\right)$ at approximately $50 \mathrm{BV}$, then remained constant, suggesting that manganese was subsequently neither taken up nor released in significant quantities. The initial decrease in the manganese concentration was partially due to the dilution as the column was initially filled with water.

From Figure 4.14, the apparent sequence of affinity of metals is $\mathrm{Cu}>\mathrm{Co}>\mathrm{Ni}>\mathrm{Zn}>\mathrm{Cd}>\mathrm{Mn}$. This was consistent with the batch tests. The curves clearly demonstrated the strong selectivity of the resin for copper over the other metals present in the solution; after $395 \mathrm{BV}$, copper had still not broken through the column. Cadmium, zinc, nickel and cobalt broke through below $20 \mathrm{BV} . \mathrm{C} / \mathrm{C}_{0}$ reached unity at approximately $25 \mathrm{BV}$ for manganese, at $160 \mathrm{BV}$ for cadmium, and at $300 \mathrm{BV}$ for zinc. For cadmium and zinc, $\mathrm{C} / \mathrm{C}_{0}$ then increased above unity, due to displacement from the resin by ions with a stronger affinity for the resin, especially copper. In reality, it is probable that after saturation of the resin, manganese would have been displaced from the resin by other metal ions, as seen for cadmium and zinc. However, the concentration of manganese was so much higher than that of the other metals present that the resulting change in manganese concentration would have been imperceptible[31]. According to the obtained results, it can be concluded that Purolite S930Plus resin is a good ionic exchanger for copper removal from diluted aqueous solutions. But it could just remove the entire $\mathrm{Cu}^{2+}$ and partly remove the $\mathrm{Co}^{2+}$ and $\mathrm{Ni}^{2+}$. It is not suitable for the purification for a large amount and range of impurities to get the high purity solution for electrorefining.

From Figure 4.15, the descending order of selectivity on the TP220 resin was $\mathrm{Cu}>\mathrm{Co} \sim \mathrm{Zn}>\mathrm{Ni}$ $>\mathrm{Cd}>\mathrm{Mn}$, which was consistent with the batch test results. All the ions in the figure except $\mathrm{Mn}^{2+}$ 
and $\mathrm{Cd}^{2+}$ had still not broken through the column after $1000 \mathrm{BV}$. Cadmium broke through at around $100 \mathrm{BV}$. Manganese broke through the column shortly after feed was supplied, due to its low affinity for the resin, and its high concentration in the feed. $\mathrm{C} / \mathrm{C}_{0}$ reached unity for manganese at approximately $100 \mathrm{BV}$.

Comparing the Figure 4.13 and Figure 4.15, the breakthrough time increased by increasing the resin quantity (from 1 to $3 \mathrm{~g}$ ), which can be attributed to the increase of binding sites numbers, and broadening the mass transfer zone[81]. It was found that when the TP220 resin quantity was at $1 \mathrm{~g}$, the cadmium broke through at around $100 \mathrm{BV}(143 \mathrm{ml}$ of solution). But when increasing it to $3 \mathrm{~g}$, cadmium had still not broken through after $662 \mathrm{BV}$ (2847 $\mathrm{ml}$ of solution).

\subsection{Summary}

The following points can be summarized from this work:

(1) For the cementation tests by manganese powder, the descending order of selectivity on the manganese powder is: $\mathrm{Cu}>\mathrm{Cd}>\mathrm{Ni}>\mathrm{Co}>\mathrm{Cr}>\mathrm{Zn}$. It is better to control the $\mathrm{pH}$ at 5.5 and reaction time at $30 \sim 45$ minutes for a higher removal rate for the impurities. But it is not suitable to get high purity manganese, as there are still plenty of impurities in the solution after purification.

(2) $\mathrm{pH}$ and resin dosages can both affect the equilibrium test results for these two resins. Lewatit ${ }^{\circledR}$ MDS TP220 showed a superior performance in comparison to Purolite S930Plus in removing the ionic impurities from synthetic solutions. 
(3) For the column tests, heavy metals, such as copper, nickel, cobalt, zinc and cadmium can be effectively and selectively removed from a manganese chloride solution using the chelating resin Lewatit ${ }^{\circledR}$ MDS TP220, and the descending order of selectivity on the chelating resin is $\mathrm{Cu}>\mathrm{Co} \sim \mathrm{Zn}>\mathrm{Ni}>\mathrm{Cd}>\mathrm{Mn}$. The obtained results for TP220 resin revealed a classic behavior, showing that the increase of the used resin quantity and, implicitly, of the bed height results in an increase of the breakthrough time. But for the Purolite S930Plus resin, it was only effective for copper removal. 


\section{Chapter 5: Electrorefining of Manganese}

\subsection{Introduction}

There is scarce literature in the field of fundamental study on manganese electrolysis from manganese chloride electrolyte, while there is vast literature on sulfate media. However, the sulfate media are not suitable for the production of high-purity manganese as sulfate will contaminate the refined metal with sulfur. Accordingly, one promising method for the production of high-purity manganese is electrodeposition from halide media. But there are some limitations such as the removal of chlorine from the anolyte and consumption of ammonia in electrowinning. These issues are not of a concern if electrorefining is used to refine manganese. In this case, manganese is dissolved from an impure manganese anode and deposited on a cathode. The predominant electrochemical reactions at the electrodes are as follows:

Cathode:

$$
\begin{gathered}
\mathrm{Mn}^{2+}+2 \mathrm{e}^{-}=\mathrm{Mn} \\
2 \mathrm{H}_{2} \mathrm{O}+2 \mathrm{e}^{-}=\mathrm{H}_{2}+2 \mathrm{OH}^{-}
\end{gathered}
$$

Reaction 5.1

Reaction 5.2

Anode:

$$
M n=M n^{2+}+2 e^{-}
$$

Reaction 5.3

In this study, the effects of the different concentrations of selected impurities added into the synthetic electrolyte feed solutions were first determined with respect to cathode purity (See Section 5.3). In addition, the synthetic electrolyte feed solutions after ion exchange were used to 
get the high purity manganese under different current density and electrolysis time (See Section 5.4); finally, some conclusions are given (See Section 5.5).

\subsection{Experimental}

\subsubsection{Materials and Solutions}

The synthetic electrolyte feed solutions for electrorefining were synthesized from manganese chloride and ammonium chloride solution as described in Section 4.2. The solution used in each test was prepared from analytical grade chemicals and Milli-Q water. The anolyte feed solution was $2 \mathrm{~mol} / \mathrm{L}$ manganese chloride and $2 \mathrm{~mol} / \mathrm{L}$ ammonium chloride solution at $\mathrm{pH} 5.5$. The catholyte feed solution was $1 \mathrm{~mol} / \mathrm{L}$ manganese chloride and $2 \mathrm{~mol} / \mathrm{L}$ ammonium chloride solution at $\mathrm{pH}$ 5.5. The anion exchange membrane was AMI-7001S, bought from Membranes International INC. in USA. Before use, the membrane was equilibrated with sodium chloride solution for one night and then rinsed with deionized water.

\subsubsection{Apparatus and Procedure}

The electrolytic membrane reactor and original methodology were developed previously by Dr. Jianming $\mathrm{Lu}$ to optimize conditions for manganese electrorefining. The electrorefining apparatus used during this study provided controlled conditions for manganese electrorefining. The apparatus is shown in Figure 5.1 and the schematic view of the electrolytic membrane reactor is shown in Figure 5.2. 
The electrolytic membrane reactor was made out of PVDF. PVDF is a specialty plastic used in applications requiring the highest purity, as well as resistance to solvents, acids and bases. The system featured an electrolytic membrane reactor and an adjustable DC power supply. The distance between the cathode and anode was kept constant $(30 \pm 1 \mathrm{~mm})$ through fixing the electrode position with the polypropylene holder. The anode was made of manganese flakes with specific dimensions of $2.00 \mathrm{~cm} \times 1.00 \mathrm{~cm} \times 0.25 \mathrm{~cm}$ and the cathode was made of 316 stainless steel with the dimensions of $7.5 \mathrm{~cm} \times 1.00 \mathrm{~cm} \times 0.2 \mathrm{~cm}$. However, the real deposit area on the cathode was kept $2 \mathrm{~cm}^{2}$ by framing the edges of cathode using electroplaters marking tape. A thermostatted water bath was filled with water and ethylene glycol, covered with plastic foams and film to avoid loss of heat and water vapour. The temperature was kept at $-10{ }^{\circ} \mathrm{C}$. A constant $\mathrm{pH}$ in the test solution was obtained in the standard $\mathrm{pH}$-stat method with a $\mathrm{pH}$ electrode and controller for adding hydrochloric acid. In order to maintain the constant $\mathrm{pH}$ in the test solution for the entire time of the experiment an alpha pH560 controller was used. This $\mathrm{pH}$-controller device was attached to a single motor drive with one mounted Masterflex L/S 13 pumpheads. The controller maintained the $\mathrm{pH}$ of the solution in a way that if the $\mathrm{pH}$ increased above 6.1 , the controller would turn on a motor drive to deliver the stock solution of hydrochloric acid via the pumphead. The motor would turn off once the solution $\mathrm{pH}$ reached below 6.1. With the use of two overhead stirrers, both catholyte and anolyte were circulated from their cathode and anode compartment tops to their mixing reservoirs, and finally back to the cathode and anode compartments at the bottom of each compartment respectively. The experimental procedure consisted of the following steps: 
- SS316 cathodes were sandblasted to improve the manganese deposit-cathode adhesion before use.

- Before each experiment, the cathode was first washed with ethyl alcohol, deionized water, and then was dried at room temperature.

- The dried cathode was first weighed and then framed by electroplating tape. The depositing area was $2 \mathrm{~cm}^{2}(1 \times 2 \mathrm{~cm})$.

- The current through the electrorefining cell was pre-determined by calculation based on the deposit area and desired current density, and then measured with a multimeter.

- Electrolyte of about $500 \mathrm{~mL}$ (catholyte and anolyte feed solution each) was freshly prepared in a volumetric flask before each experiment: impurities were added according to the test compositions.

- The feed solution reservoirs containing electrolytes were placed in the water bath to equilibrate. Catholyte and anolyte solutions $(50 \mathrm{ml}$ each) and $\mathrm{pH}$ probes were also placed in the $\mathrm{pH}$ control reservoirs. Two $\mathrm{pH}$ probes with temperature compensation calibrated using $\mathrm{pH}$ buffers 7 and 4 ahead of the time.

- When the desired temperature $\left(-10^{\circ} \mathrm{C}\right)$ in the electrolyte was reached, the electrorefining process was started. The process time was recorded with a timer. The acid consumption was recorded with a balance.

- During the 24-hour duration, voltage measurements were once per hour using multimeter and the mean value was used to calculate the specific energy consumption.

- When each electrorefining test was done, the cathode and anode were taken out of the electrolyte and washed using Milli-Q water. Nitrogen gas and soft tissues were used to 
blow off and absorb the water remaining on the cathode surface. The cathode with deposited manganese and the anode were weighed and recorded until the value did not change any more. Manganese electrodeposits and the catholyte were analyzed by ICPMS by 5NPLUS.

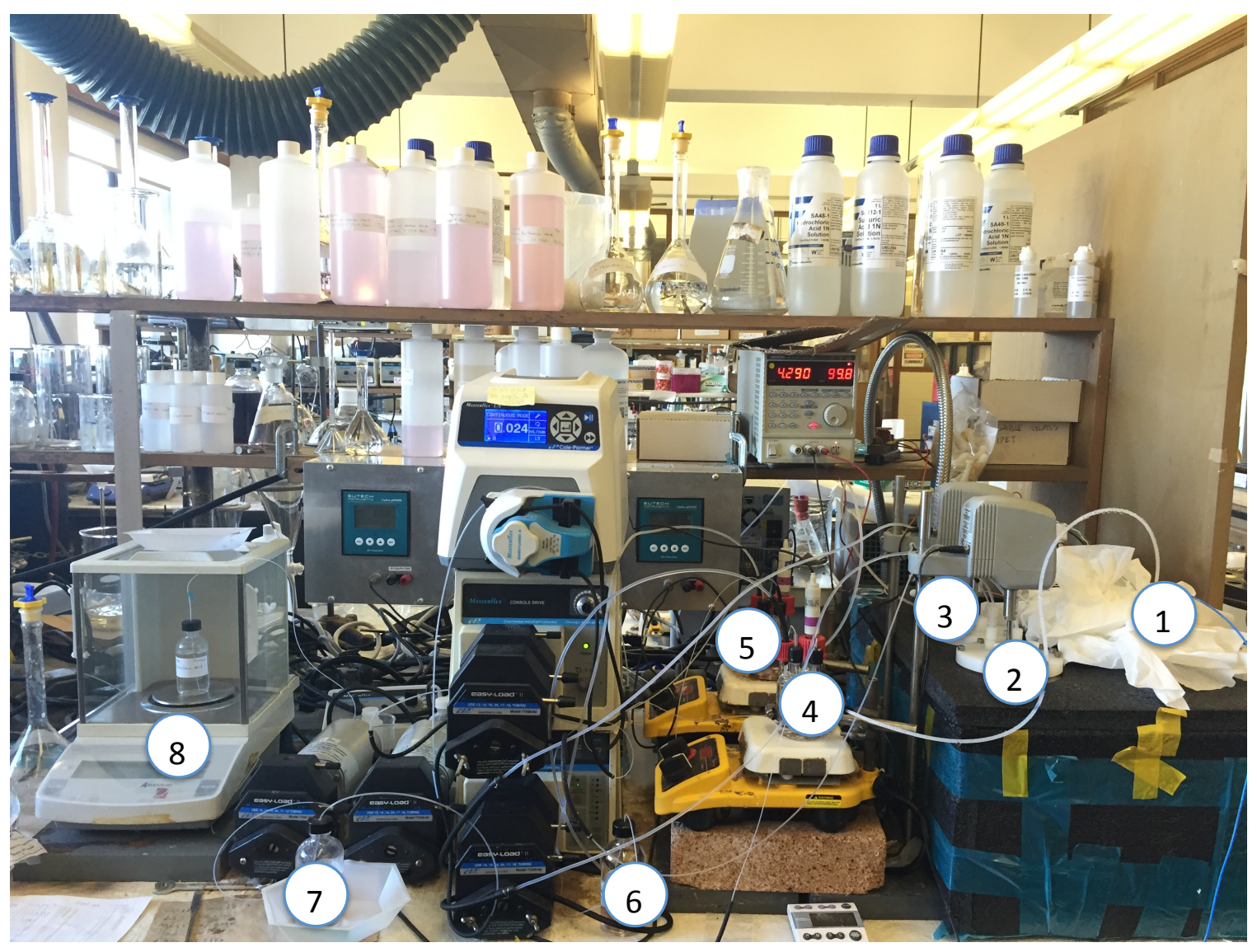

Figure 5.1 Experimental apparatus for electrorefining tests

(1-Reactor, 2-Catholyte feed solution reservoir, 3-Anolyte feed solution reservoir, 4-Catholyte pH control reservoir, 5-Anolyte pH control reservoir, 6-Catholyte feed solution supply container, 7-Excess anolyte solution container, 8Catholyte acid consumption) 


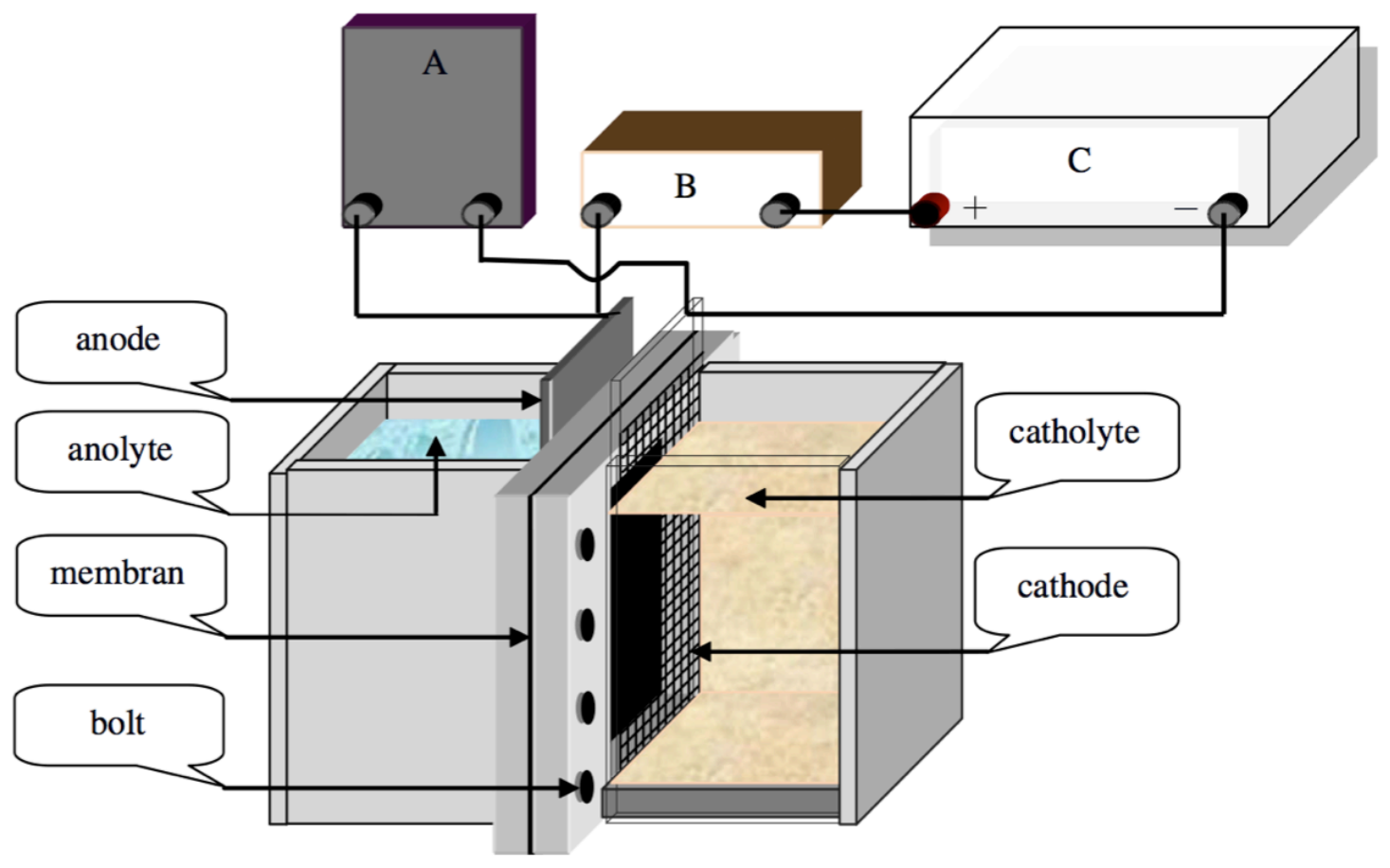

Figure 5.2 Schematic view of the electrolytic membrane reactor[69]

(A-Voltmeter, B-Ammeter, $C$-DC power supply)

\subsubsection{Evaluation Factors and Analytical Methods}

There are some key factors to evaluate the electrorefining process, in particular Cathodic Current Efficiency (CCE) and Specific Energy Consumption (SEC). To determine the cathodic current efficiency related to the manganese deposit, Equation 5.4 was used, and Equation 5.5 for the specific energy consumption (unit manganese quantity on the cathode) calculation was also necessary[69].

$$
\eta_{c}=\frac{p}{E_{M n} I_{c} A_{c}}\left(\frac{\Delta M c}{\Delta t}\right)
$$




$$
W_{M n}=\frac{C V \times 1000}{E_{M n} \times \eta_{c}}
$$

In Equation 5.4 and 5.5, $\eta_{c}$ is the cathodic current efficiency is expressed as a percentage, and $\frac{\Delta M c}{\Delta t}(\mathrm{~g} / \mathrm{h})$ is the weight gain of the cathode mass over the time interval $\Delta t . A_{c}$ is the effective cathode area $\left(\mathrm{m}^{2}\right)$, and $I_{c}$ is the applied apparent current density $\left(\mathrm{A} / \mathrm{m}^{2}\right) \cdot p$ is the purity of the deposited manganese. $E_{M n}$ is the electrochemical equivalent and its value is $1.025 \mathrm{~g} /(\mathrm{A} \cdot \mathrm{h}) . W_{M n}$ is the specific energy consumption as $\mathrm{KWh} / \mathrm{t}$ for the metallic manganese, and $\mathrm{CV}$ is the cell voltage $(\mathrm{V})$.

Deposit morphology is also a key factor to evaluate the quality of deposited manganese. The micro-morphology of manganese deposit was observed by Scanning Electronic (SEM) and X-ray Diffraction.

\subsection{Effect of Impurities}

The individual and synergistic uses of impurities in catholyte solutions and the electrorefining conditions of the experiments were organized as shown in Table 5.1. The impurities tested were $\mathrm{Cu}^{2+}, \mathrm{Ni}^{2+}, \mathrm{Cd}^{2+}, \mathrm{Zn}^{2+}$, and $\mathrm{Co}^{2+}$ in the chloride forms. During the tests, other conditions such as the current density, $\mathrm{pH}$ and temperature were kept constant. 
Table 5.1 Experimental conditions for the effect of impurities

\begin{tabular}{|l|l|}
\hline Anode & Manganese flakes \\
\hline Cathode & Sandblasted SS316 stainless steel \\
\hline Anolyte solution & $2 \mathrm{M} \mathrm{MnCl}_{2}+2 \mathrm{M} \mathrm{NH}_{4} \mathrm{Cl}$ \\
\hline Catholyte solution & $1 \mathrm{M} \mathrm{MnCl}{ }_{2}+2 \mathrm{M} \mathrm{NH}_{4} \mathrm{Cl}+0 \mathrm{ppb} / 50 \mathrm{ppb} / 100 \mathrm{ppb} / 150 \mathrm{ppb} / 200 \mathrm{ppb}$ \\
& $/ 200 \mathrm{ppb} \mathrm{Zn}{ }^{2+}$ impurities \\
\hline Current density & $500 \mathrm{~A} / \mathrm{m}^{2}$ \\
\hline Batch temperature & $-10^{\circ} \mathrm{C}$ \\
\hline Time of deposition & $24 \mathrm{~h}$ \\
\hline
\end{tabular}

The cathodic and anodic current efficiencies, specific energy consumption and manganese deposit purity for each manganese electrorefining test were first evaluated. The results are shown in Table 5.2. As can been seen from the results, the addition of the impurities in the electrolyte changed the manganese purity compared to the additives-free test. When increasing the impurities levels, the purity of the manganese deposit decreased. However, for the cathodic current efficiency (CCE), the addition of the impurities caused a considerable decrease firstly but then an increase when the impurities concentration was over 100 ppb. However, the anodic current efficiency (ACE) and specific energy consumption increased firstly and then decreased. The hydrogen overpotential on zinc is greater than that on manganese and the zinc ions increase the overpotential. An addition of $0.15-5.0 \mathrm{mg} / 1$ of $\mathrm{Zn}^{2+}$ to the catholyte in the manganese deposition cell has been reported to increase the cathode current efficiency [56] and decrease the minimum current density necessary for manganese deposition on the cathodes. In order to test the effect of the $\mathrm{Zn}^{2+}$ for the cathodic current efficiency, only $200 \mathrm{ppb} \mathrm{Zn}^{2+}$ was added to the feed solution for the electrorefining test. The cathodic current efficiency was $82.77 \%$, almost the same values as the impurities concentrations over $100 \mathrm{ppb}$. So an addition of $0.15-5.0 \mathrm{mg} / 1 \mathrm{Zn}^{2+}$ in the catholyte in the manganese deposition cell does increase the cathodic current efficiency. 
Table 5.2 Experimental data for impurities use

\begin{tabular}{|c|c|c|c|c|}
\hline Sample \# & $\mathrm{ACE}(\%)$ & $\mathrm{CCE}(\%)$ & $\mathrm{SEC}(\mathrm{KWh} / \mathrm{t})$ & Mn purity $(\%)$ \\
\hline Feed solution & 105.12 & 77.35 & 5360 & 99.9959 \\
\hline Feed solution $+50 \mathrm{ppb}$ & 105.80 & 74.82 & 5555 & 99.9908 \\
\hline Feed solution $+100 \mathrm{ppb}$ & 104.56 & 82.65 & 5004 & 99.9899 \\
\hline Feed solution $+150 \mathrm{ppb}$ & 104.43 & 83.04 & 5005 & 99.9873 \\
\hline Feed solution $+200 \mathrm{ppb}$ & 104.61 & 82.18 & 5045 & 99.9821 \\
\hline Feed solution $+200 \mathrm{ppb} \mathrm{Zn}^{2+}$ (f) & 106.37 & 82.77 & 5009 & 99.9941 \\
\hline
\end{tabular}

For the catholyte solution, the $\mathrm{Cu}^{2+}, \mathrm{Ni}^{2+}, \mathrm{Cd}^{2+}, \mathrm{Zn}^{2+}$, and $\mathrm{Co}^{2+}$ in the chloride forms were added. The concentrations of them in the feed solution and the deposit manganese were also evaluated by ICP-MS (See Figure 5.3).

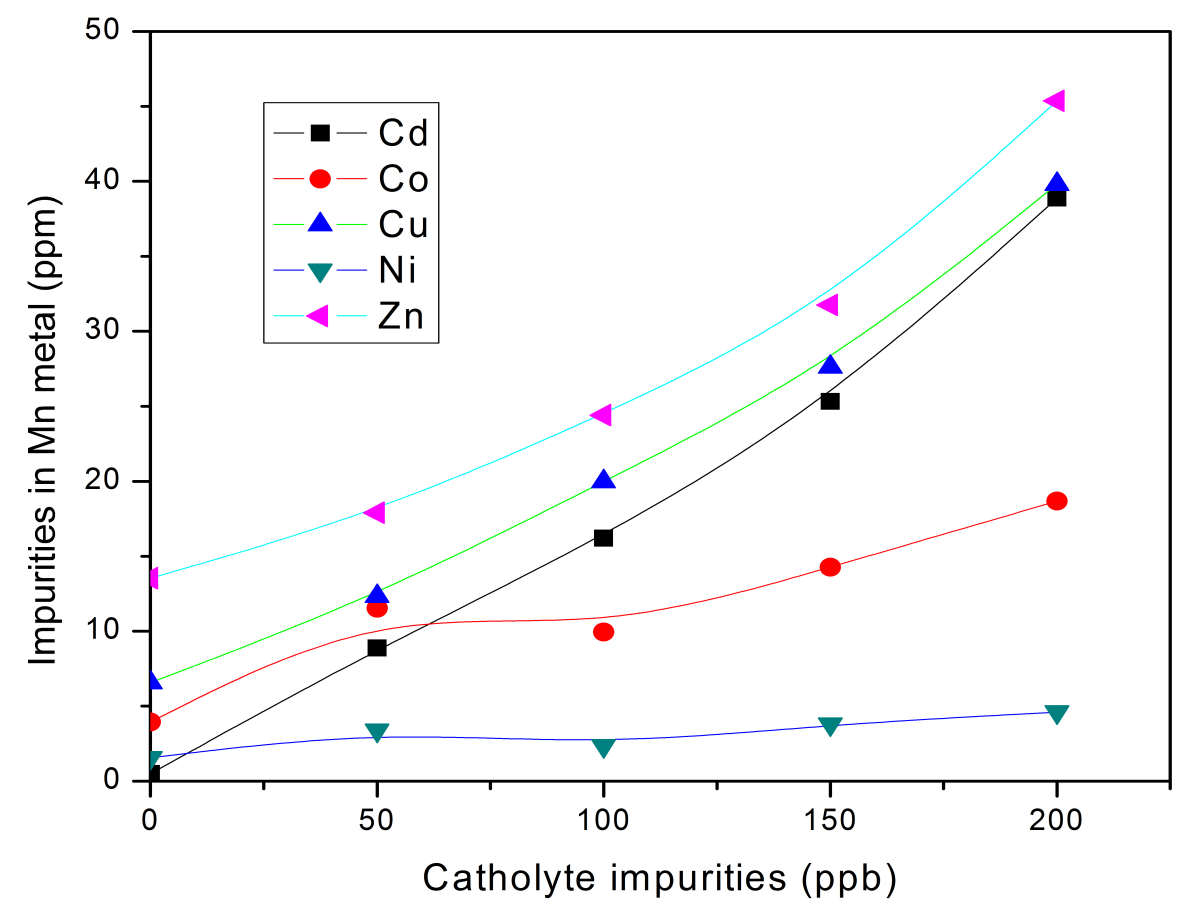

Figure 5.3 Effect of impurities on manganese electrorefining 
As shown in Figure 5.3, the impurity contamination increased with increasing the impurity concentrations in the catholyte. Contamination was found to be least in the case of $\mathrm{Ni}^{2+}$ and greatest in the case of $\mathrm{Zn}^{2+}$. The contamination might be due to precipitation of the respective hydroxides or basic salts at the surface and subsequent adsorption or codeposition along with manganese. It was found that the increasing rate of $\mathrm{Cd}^{2+}$ was the highest, and the next was $\mathrm{Cu}^{2+}$ and $\mathrm{Zn}^{2+}$. As expected, the $\mathrm{Zn}^{2+}, \mathrm{Cd}^{2+}$ and $\mathrm{Cu}^{2+}$ should be removed from the catholyte solution before electrorefining in order to get the high purity manganese metal.

The macro-morphologies of manganese deposits plated at various concentrations of additives were observed, as shown in Figure 5.4. At a low temperature $-10^{\circ} \mathrm{C}$, the manganese deposits were light gray, smooth and fined-grained. In electrolyte with impurities added, the dendritic deposits were weakly adherent to the substrate and easy to peel off. Large isolated manganese crystals were formed especially on the edges of depositing area. With increasing the impurities concentration from $0 \mathrm{ppb}$ to $200 \mathrm{ppb}$, the deposit became rough and uneven. The morphology became worse as some fine cavities presented on the deposits. 


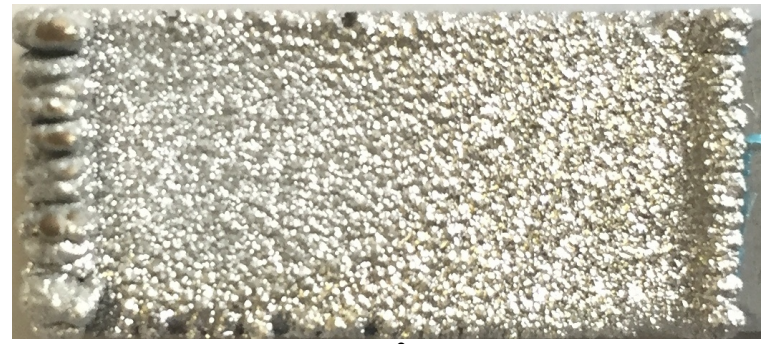

(a) Feed solution, $500 \mathrm{~A} / \mathrm{m}^{2}, 24 \mathrm{~h},-10{ }^{\circ} \mathrm{C}$

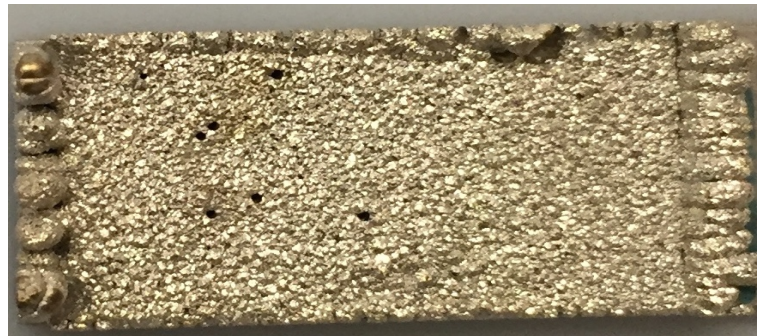

(c) Feed solution $+100 \mathrm{ppb}, 500 \mathrm{~A} / \mathrm{m}^{2}, 24 \mathrm{~h},-10{ }^{\circ} \mathrm{C}$

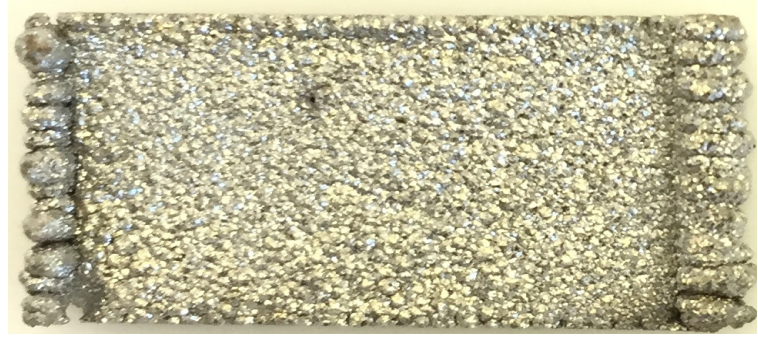

(e) Feed solution+200 ppb, $500 \mathrm{~A} / \mathrm{m}^{2}, 24 \mathrm{~h},-10{ }^{\circ} \mathrm{C}$

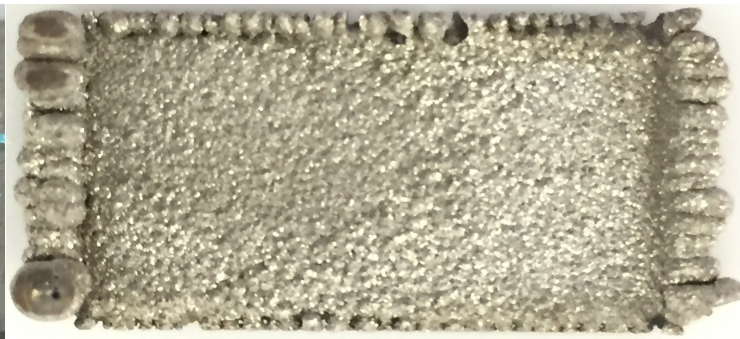

(b) Feed solution $+50 \mathrm{ppb}, 500 \mathrm{~A} / \mathrm{m}^{2}, 24 \mathrm{~h},-10{ }^{\circ} \mathrm{C}$

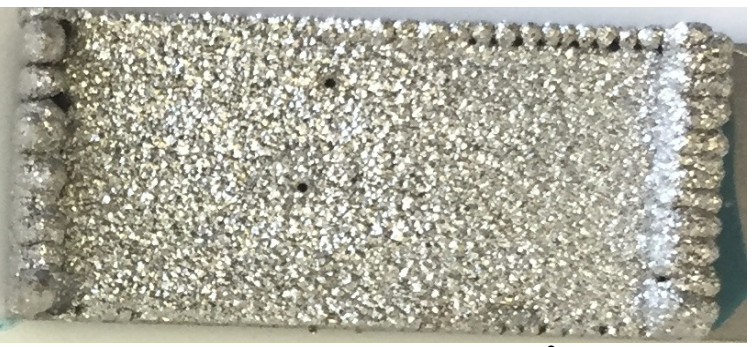

(d) Feed solution+150 ppb, $500 \mathrm{~A} / \mathrm{m}^{2}, 24 \mathrm{~h},-10{ }^{\circ} \mathrm{C}$

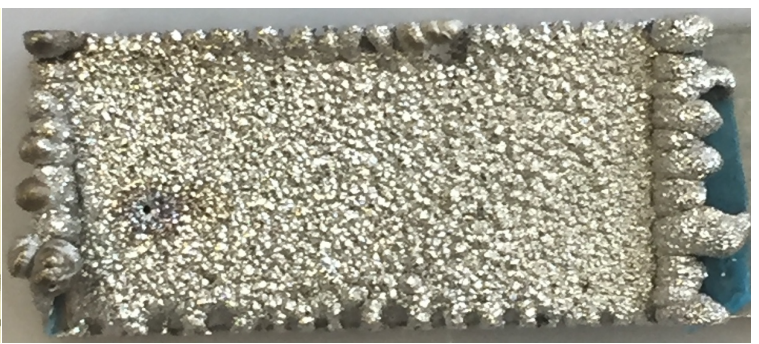

(f) Feed solution+200 ppb Zn ${ }^{2+}, 500 \mathrm{~A} / \mathrm{m}^{2}, 24 \mathrm{~h},-10{ }^{\circ} \mathrm{C}$

Figure 5.4 Manganese deposits produced from the solutions with different amount of impurities at $-10{ }^{\circ} \mathrm{C}$, $500 \mathrm{~A} / \mathrm{m}^{2}, 24$ hours of deposition.

Samples (b), (c), (d), (e): $\mathrm{Cu}^{2+}, \mathrm{Ni}^{2+}, \mathrm{Cd}^{2+}, \mathrm{Zn}^{2+}$, and $\mathrm{Co}^{2+}$ in the chloride forms were added into tested solutions

Some manganese deposits with good morphology were sent for SEM and XRD tests for more detailed analysis of the micro-structure (See Figure 5.5 Figure 5.8). Figure 5.5 and Figure 5.6 showed the SEM photographs of a typical surface of deposited manganese. It was found that the numerous fine crystals grew into large and well-defined pyramids after 24 hours and some micro-cracks between the manganese crystals were present in the figures. Figure 5.5 shows the 
morphology of electrodeposited manganese from an additive-free solution where randomly oriented, fine-shaped crystallites were located in the form of close-packed colonies. When increasing the impurities levels, it benefited the crystal growth, which made the surface relatively coarse and uneven. The manganese deposits were confirmed to be the metallic $\alpha$-Mn phase when comparing the Figure 5.7 and 5.8 with the standard patterns.

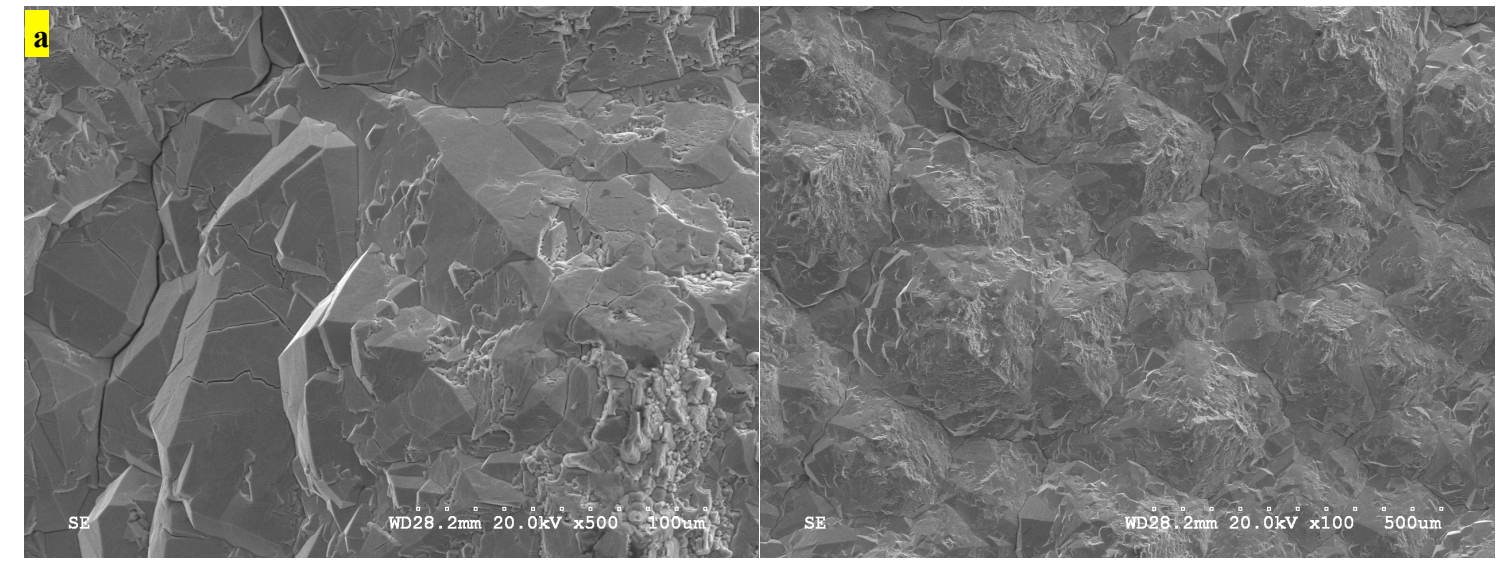

Figure 5.5 Scanning electron microscope (SEM) diagrams for sample a (Feed solution)

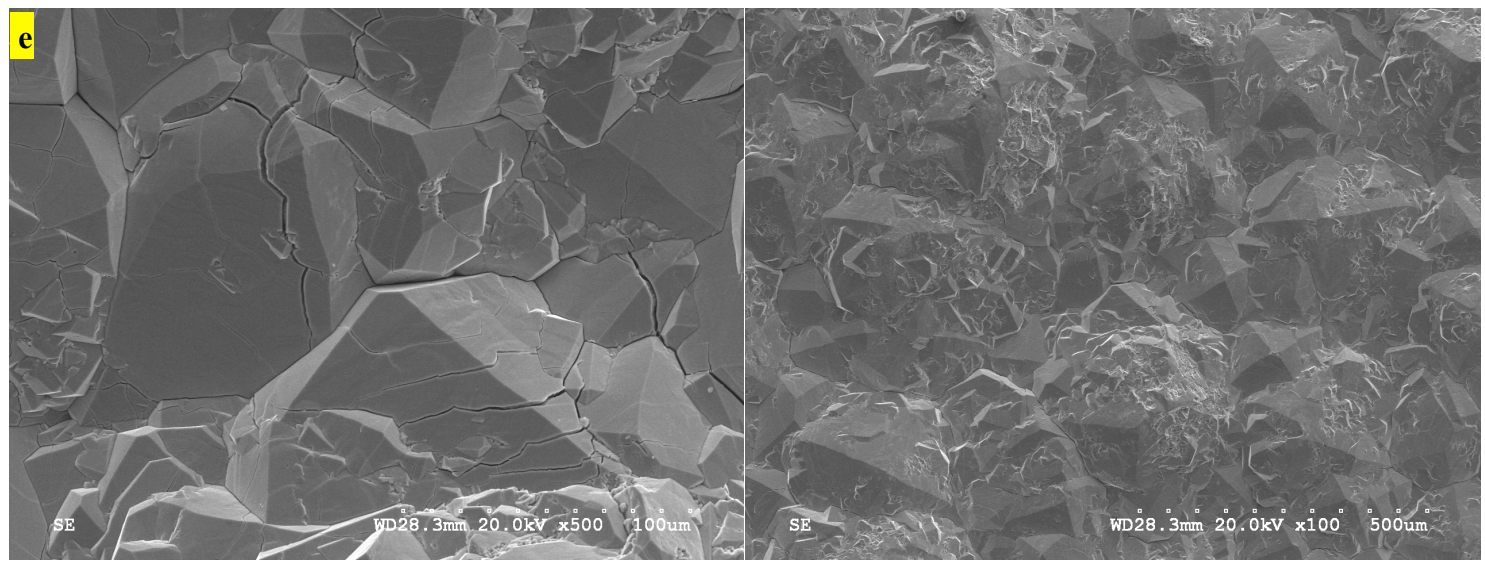

Figure 5.6 Scanning electron microscope (SEM) diagrams for sample e (Feed solution+200 ppb) 

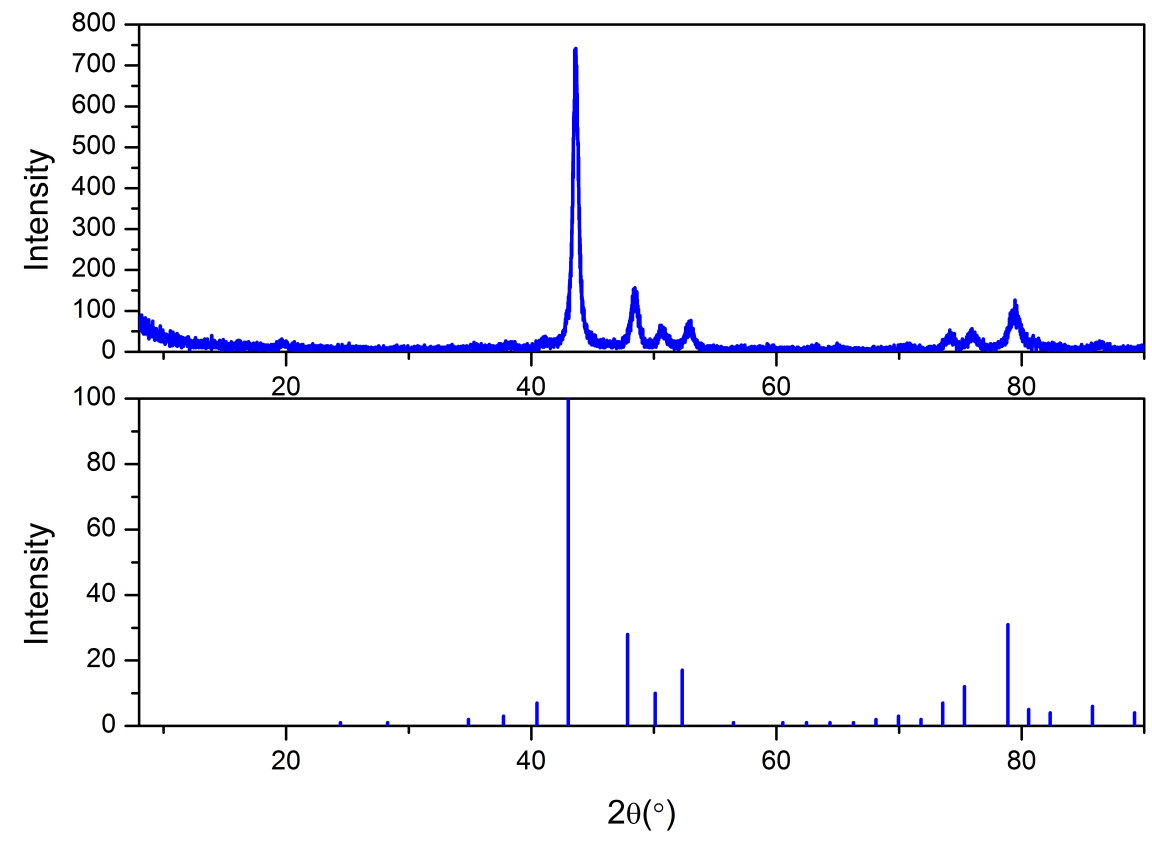

Figure 5.7 XRD diagram for sample a (Feed solution)

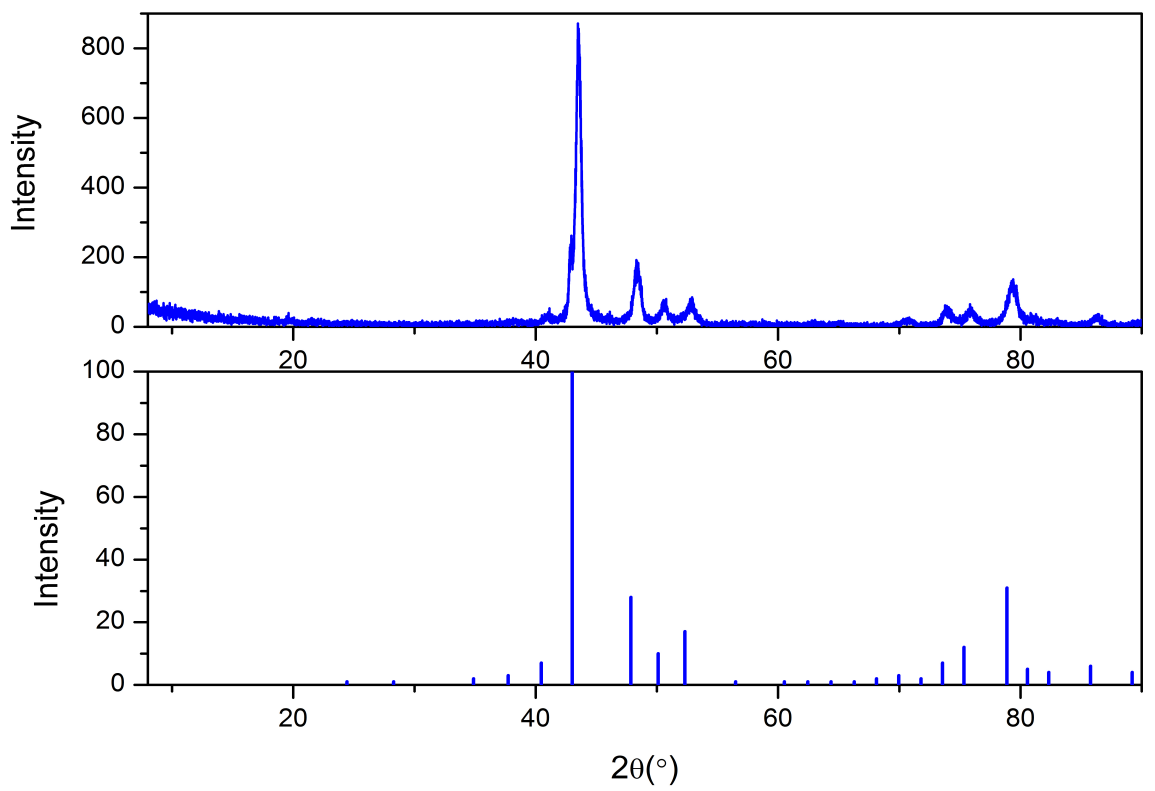

Figure 5.8 XRD diagram for sample e (Feed solution+200 ppb) 


\subsection{Effect of Operation Conditions}

The solution for the test was the synthetic feed solution after ion exchange. The composition for the purified catholyte solution was: $\left.110 \mathrm{~g} / \mathrm{L} \mathrm{Mn} \mathrm{(as} \mathrm{MnCl}_{2}\right), 1 \mathrm{mg} / \mathrm{L} \mathrm{Si}$ and trace amount $(<10$ $\mu \mathrm{g} / \mathrm{L})$ of metal impurities $\left(\mathrm{Cu}^{2+}, \mathrm{Ni}^{2+}, \mathrm{Cd}^{2+}, \mathrm{Zn}^{2+}\right.$, and $\left.\mathrm{Co}^{2+}\right)$. The operating parameters in this section were organized as shown in Table 5.3.

Table 5.3 Experimental conditions for the effect of operation conditions

\begin{tabular}{|l|l|}
\hline Anode & Manganese flakes \\
\hline Cathode & SS316 stainless steel \\
\hline Anolyte solution & $2 \mathrm{M} \mathrm{MnCl}_{2}+2 \mathrm{M} \mathrm{NH}_{4} \mathrm{Cl}$ after Ion Exchange \\
\hline Catholyte solution & $1 \mathrm{M} \mathrm{MnCl}_{2}+2 \mathrm{M} \mathrm{NH}_{4} \mathrm{Cl}$ after Ion Exchange \\
\hline Current density & $250 / 400 / 500 / 750 / 1000 \mathrm{~A} / \mathrm{m}^{2}$ \\
\hline Batch temperature & $-10^{\circ} \mathrm{C}$ \\
\hline Cathode & Sandblasted/Repeated use without being sandblasted again \\
\hline
\end{tabular}

The cathodic and anodic current efficiencies, specific energy consumption and manganese purity for each electrorefining test were first evaluated. The results are organized and shown in Table 5.4. The manganese purity for all tested parameters was over 99.99\% (See Table 5.4). The various parameters showed only a slight influence on the manganese purity in the electrorefining process. 
Table 5.4 Experimental data for optimizing operation conditions

\begin{tabular}{|c|c|c|c|c|c|c|}
\hline $\begin{array}{c}\text { Current density } \\
\left(\mathrm{A} / \mathrm{m}^{2}\right)\end{array}$ & $\begin{array}{c}\text { Electrolysis } \\
\text { time }(\mathrm{h})\end{array}$ & $\begin{array}{c}\text { Cathode usage } \\
\text { frequency }\end{array}$ & ACE $(\%)$ & CCE $(\%)$ & $\begin{array}{c}\text { SEC } \\
(\mathrm{KWh} / \mathrm{t})\end{array}$ & $\begin{array}{c}\text { Mn purity } \\
(\%)\end{array}$ \\
\hline $250(\mathrm{~g})$ & 48.0 & First time & 107.42 & 67.52 & 3077 & 99.9975 \\
\hline $400(\mathrm{~h})$ & 30.0 & First time & 106.11 & 78.15 & 4244 & 99.9972 \\
\hline $500(\mathrm{i})$ & 24.0 & First time & 106.28 & 79.38 & 5223 & 99.9984 \\
\hline $750(\mathrm{j})$ & 16.0 & First time & 103.77 & 79.98 & 7782 & 99.9974 \\
\hline $1000(\mathrm{k})$ & 12.0 & First time & 102.87 & 79.59 & 10419 & 99.9967 \\
\hline $500(\mathrm{l})$ & 48.0 & First time & 105.28 & 72.66 & 5706 & 99.9975 \\
\hline $500(\mathrm{~m})$ & 24.0 & $2^{\text {nd }}$ time untreated & 104.79 & 77.65 & 5339 & 99.9905 \\
\hline $500(\mathrm{n})$ & 24.0 & $3^{\text {rd }}$ time untreated & 104.16 & 72.74 & 5699 & 99.9985 \\
\hline
\end{tabular}

Current density has a remarkable and significant influence on declining energy consumption. In order to keep the same thickness of the manganese deposit, the electrolysis time was varied with different current densities. As can been seen from the results (See Figure 5.9), the manganese cathodic current efficiency first increased with increasing current density, reached a maximum value and then decreased. It is known that at lower current densities, the efficiency of manganese deposition is affected by self-dissolution of the manganese electrodeposited. As both water electrolysis and manganese dissolution contribute to hydrogen evolution, the hydrogen evolution rate is high, and the manganese deposition rate appears to be low[55], [69]. The anodic current efficiency first decreased and then increased when the current density was over $750 \mathrm{~A} / \mathrm{m}^{2}$. But the anodic current efficiencies were over $100 \%$ due to the manganese self-dissolution. When the current density increased from $750 \mathrm{~A} / \mathrm{m}^{2}$ to $1000 \mathrm{~A} / \mathrm{m}^{2}$, the evolution of hydrogen increased on the cathode, and the efficiencies of manganese deposition fell accordingly. With increasing current density from $250 \mathrm{~A} / \mathrm{m}^{2}$ to $1000 \mathrm{~A} / \mathrm{m}^{2}$, the increasing cell voltage resulted in the increase of specific energy consumption. The specific energy consumption increased from 3077 to $10419 \mathrm{KWh} / \mathrm{t}$ when the current density was increased from 250 to $1000 \mathrm{~A} / \mathrm{m}^{2}$. This result was 
consistent with the observed changes in the current efficiency and cell voltage. Thus, the optimum current density region in the $\mathrm{MnCl}_{2}-\mathrm{NH}_{4} \mathrm{Cl}$ system appears to be between $400-750$ $\mathrm{A} / \mathrm{m}^{2}$.

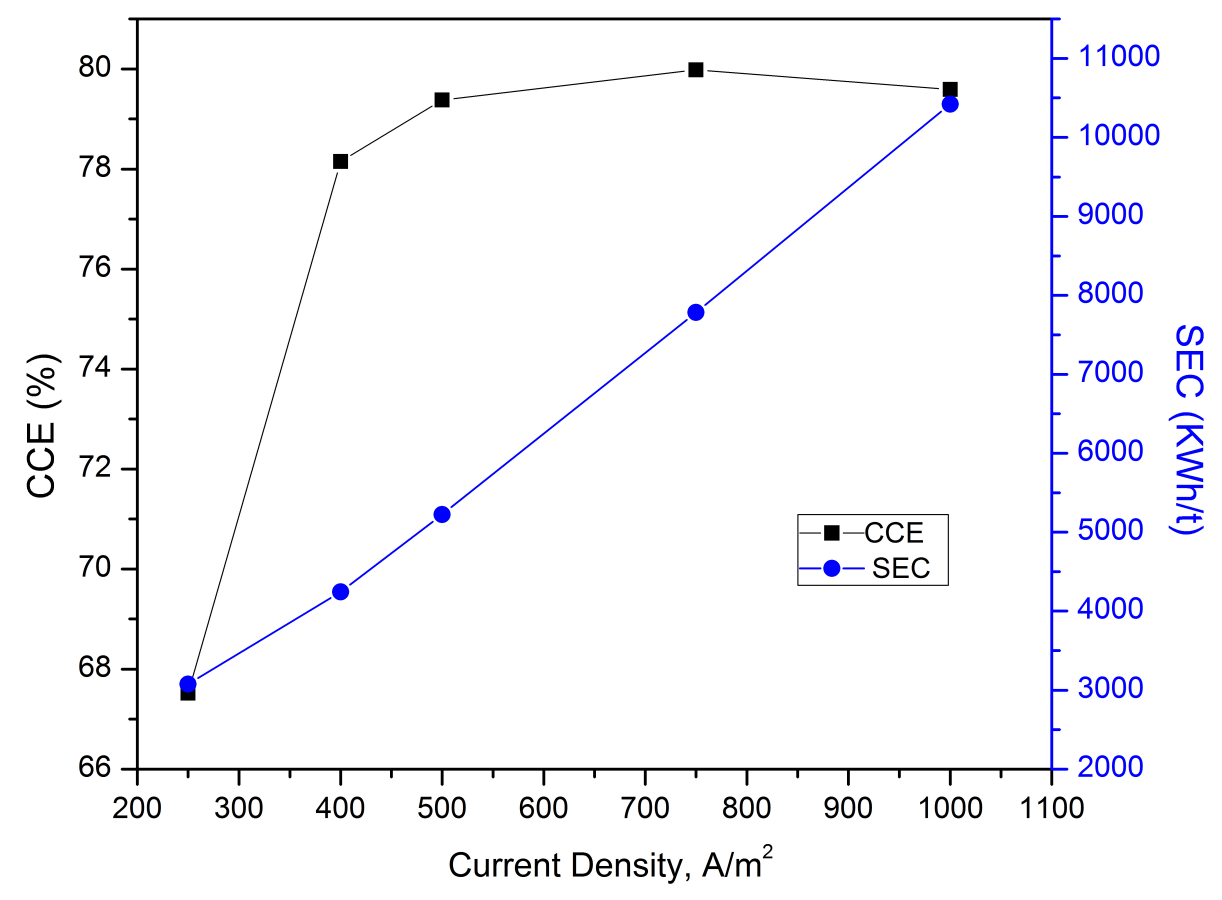

Figure 5.9 Effect of current density on the current efficiency and specific energy consumption

With increasing deposition time from 24 hours to 48 hours, the manganese current efficiency decreased and the deposit became more dendritic when the current density was kept at $500 \mathrm{~A} / \mathrm{m}^{2}$. A short deposition time may be used at a high current density while a long deposition time should be used at a low current density. The effects of cathode usage frequency on the current efficiency and manganese purity in the chloride system were also studied under the conditions (See Table 5.4 and Figure 5.10). Before each test, the cathode was sandblasted to improve the 
manganese deposit-cathode adhesion. But for the repeated use tests, the cathode was reused without being sandblasted again. It was found that the cathodic current efficiency decreased slowly for the second time use and decreased rapidly with an increase in the number of times the cathode used when the current density was kept at $500 \mathrm{~A} / \mathrm{m}^{2}$ and the electrolysis time was kept at 24 hours. The more times the cathode was used, the lower the current efficiency, which indicated that the lifetime of the cathode for manganese electrorefining was short. This is probably due to the fact that after the cathode was used, the surface condition of it was changed to a lower deposit-cathode adhesion. So manganese re-dissolved in some local areas due to the loss of cathodic protection accompanied by hydrogen evolution.

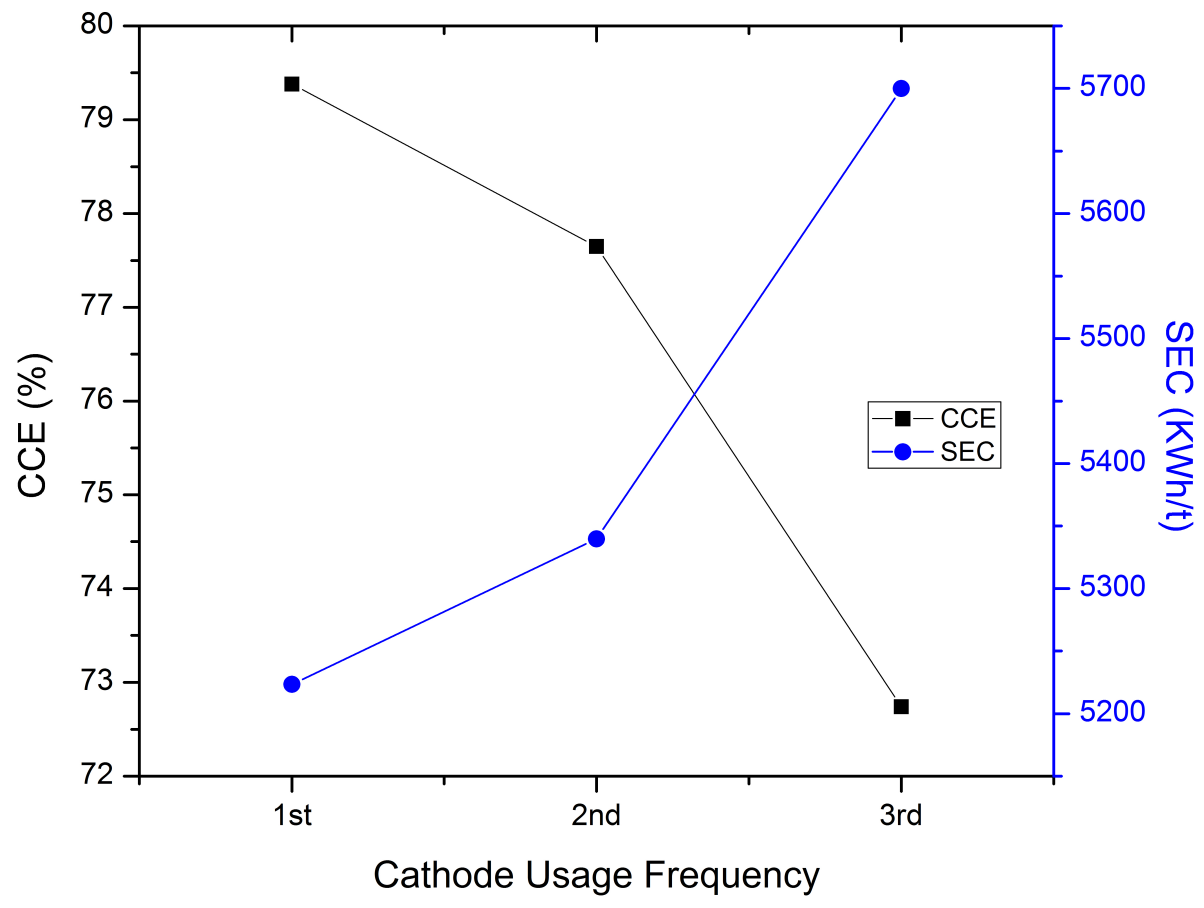

Figure 5.10 Effect of cathode usage frequency on the current efficiency and specific energy consumption 
In electrowinning and electrorefining of metals, a cell with two equal parallel-plane electrodes represents the elementary cell of electrode arrangement. If the electrode edges do not touch the sidewalls of the cell, the current density is higher at the edges than that at the center of the electrode since the current passes partially in the region outside the gap between the two electrodes. In some cases the deposit in the central part of the cathode is compact and flat while dendrites are produced at the edges[82]. The Figure 5.11 displays the influence of operating parameters on the morphologies of manganese deposit. The low temperature resulted in smoother surfaces. At different current densities, after deposition, homogeneous and silvery bright $\mathrm{Mn}$ deposits were obtained on all samples. It is clear that there was no significant difference in surface morphology of the Mn deposit when the current density was in the range of 250-500 A/m $\mathrm{m}^{2}$. However, when current densities exceeded $750 \mathrm{~A} / \mathrm{m}^{2}$, a lower current efficiency was obtained and black deposits formed at the edges of the samples. These black films were amorphous and contained oxyhydroxides that are known to greatly inhibit crystal growth, which decreases the current efficiency[55].

With increasing deposition time, manganese deposits gradually became rougher, and nodules grew up and outward, forming cauliflower-like dendritic structures or even "trees", resulting in trapping of electrolyte in electrolytic manganese, difficulty stripping of manganese deposits from cathodes, and even difficulty in removing cathodes from cells.

For the untreated cathode, there was no significant difference in surface morphology of the Mn deposit compared with the treated cathode. Some SEM images were taken for manganese deposits obtained under different operation parameters (See Figure 5.12 Figure 5.19). From the 
figures, it was found that some micro-cracks between the manganese crystals were present. When increasing the current density from 250 to $1000 \mathrm{~A} / \mathrm{m}^{2}$ (See Figure 5.12 Figure 5.16), it benefited the crystal growth, which made the surface relatively coarse and uneven.

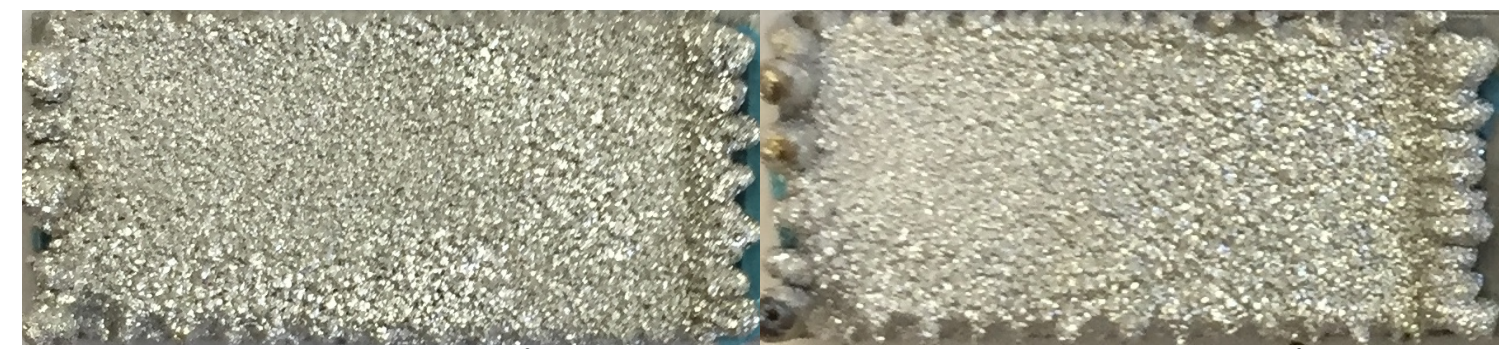

(g) Feed solution after IX, $250 \mathrm{~A} / \mathrm{m}^{2}, 48 \mathrm{~h},-10{ }^{\circ} \mathrm{C}$

(h) Feed solution after IX, $400 \mathrm{~A} / \mathrm{m}^{2}, 30 \mathrm{~h},-10{ }^{\circ} \mathrm{C}$

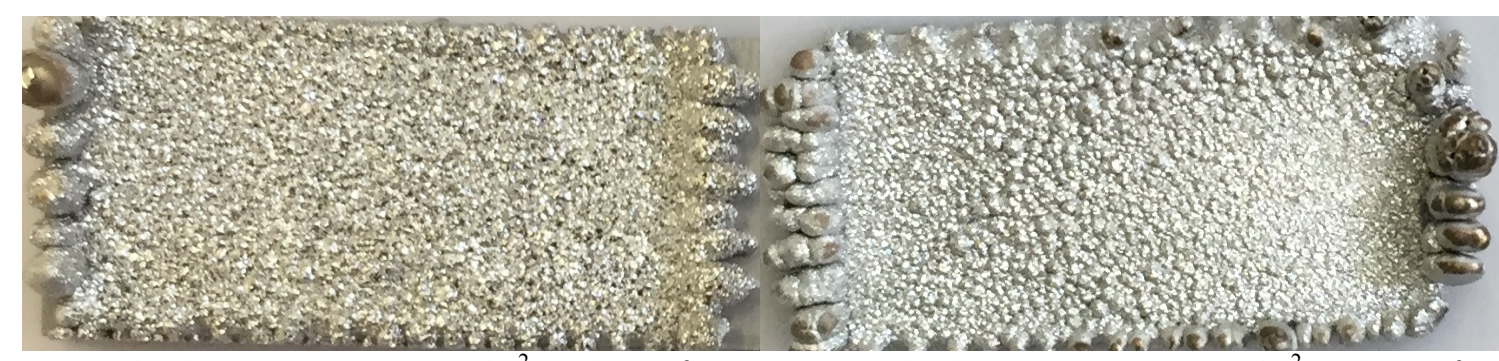

(i) Feed solution after IX, $500 \mathrm{~A} / \mathrm{m}^{2}, 24 \mathrm{~h},-10{ }^{\circ} \mathrm{C}$

(j) Feed solution after IX, $750 \mathrm{~A} / \mathrm{m}^{2}, 16 \mathrm{~h},-10{ }^{\circ} \mathrm{C}$

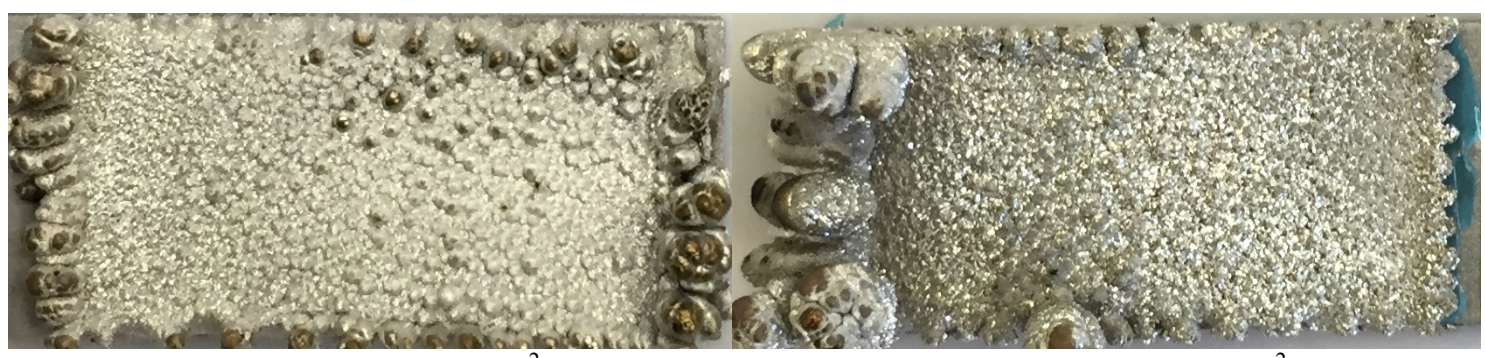

(k) Feed solution after IX, $1000 \mathrm{~A} / \mathrm{m}^{2}, 12 \mathrm{~h},-10{ }^{\circ} \mathrm{C}$

(1) Feed solution after IX, $500 \mathrm{~A} / \mathrm{m}^{2}, 48 \mathrm{~h},-10{ }^{\circ} \mathrm{C}$

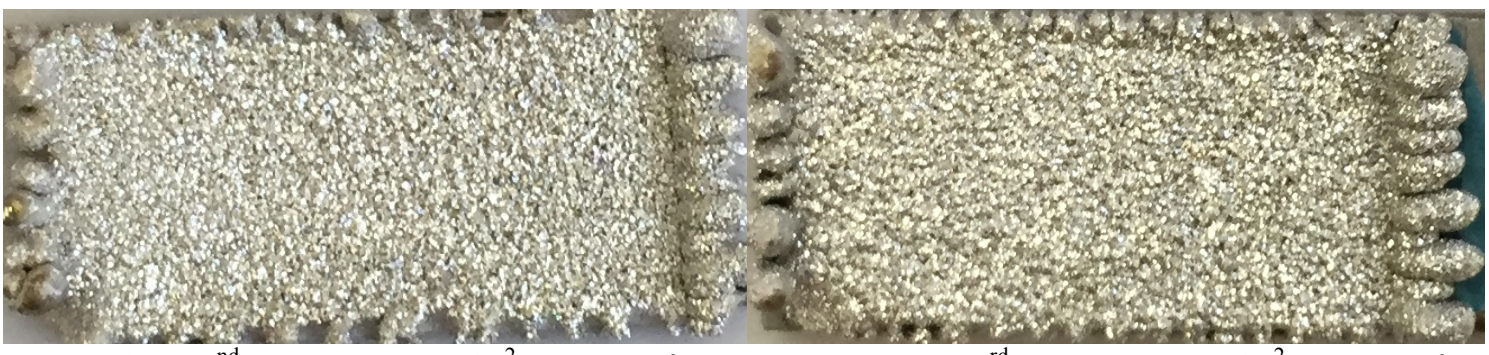

(m) Cathode $2^{\text {nd }}$ time use, $500 \mathrm{~A} / \mathrm{m}^{2}, 24 \mathrm{~h},-10{ }^{\circ} \mathrm{C}$

(n) Cathode $3^{\text {rd }}$ time use, $500 \mathrm{~A} / \mathrm{m}^{2}, 24 \mathrm{~h},-10{ }^{\circ} \mathrm{C}$

Figure 5.11 Manganese deposits produced from solutions with different operation conditions at $-10{ }^{\circ} \mathrm{C}$ 


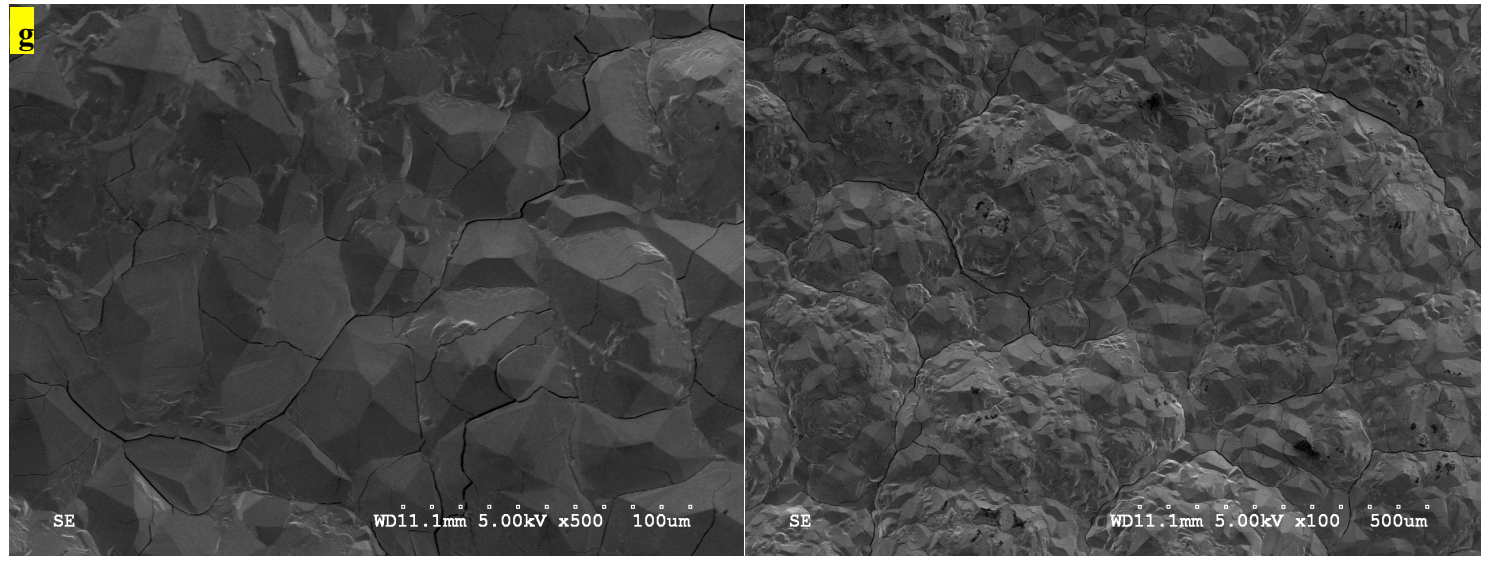

Figure 5.12 Scanning electron microscope diagrams for sample g (Current density at $250 \mathrm{~A} / \mathrm{m}^{2}, 48 \mathrm{~h}$ )

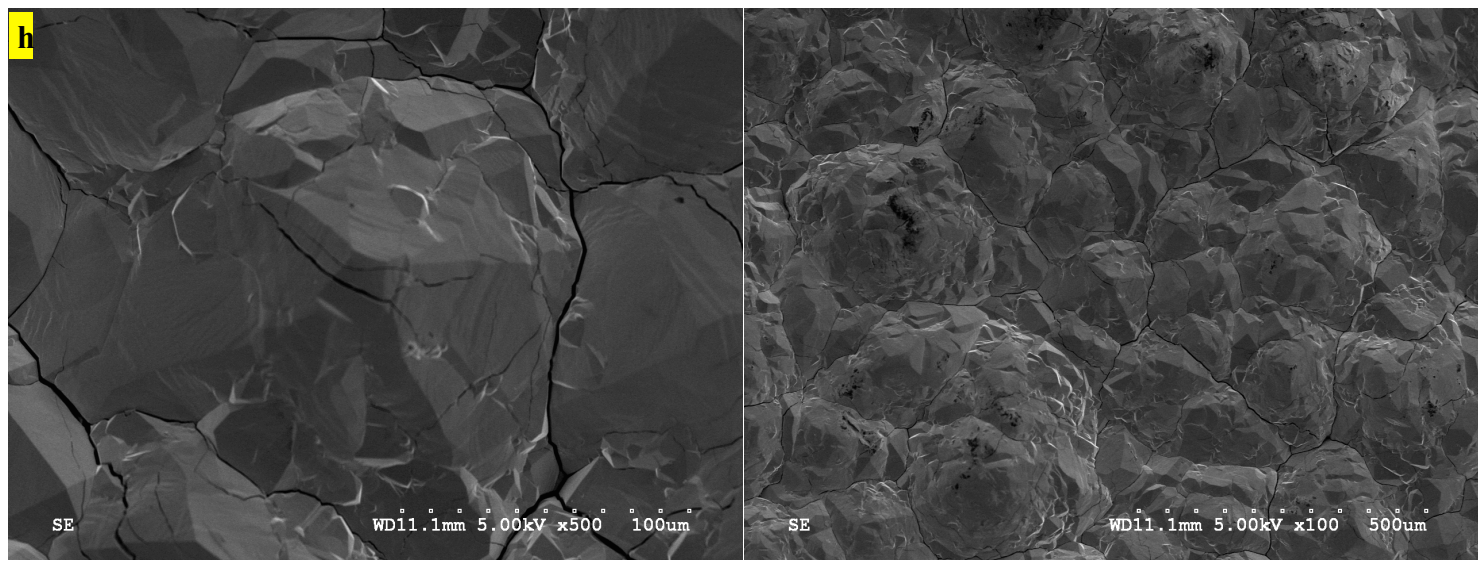

Figure 5.13 Scanning electron microscope diagrams for sample $h$ (Current density at $400 \mathrm{~A} / \mathrm{m}^{2}, 30 \mathrm{~h}$ )

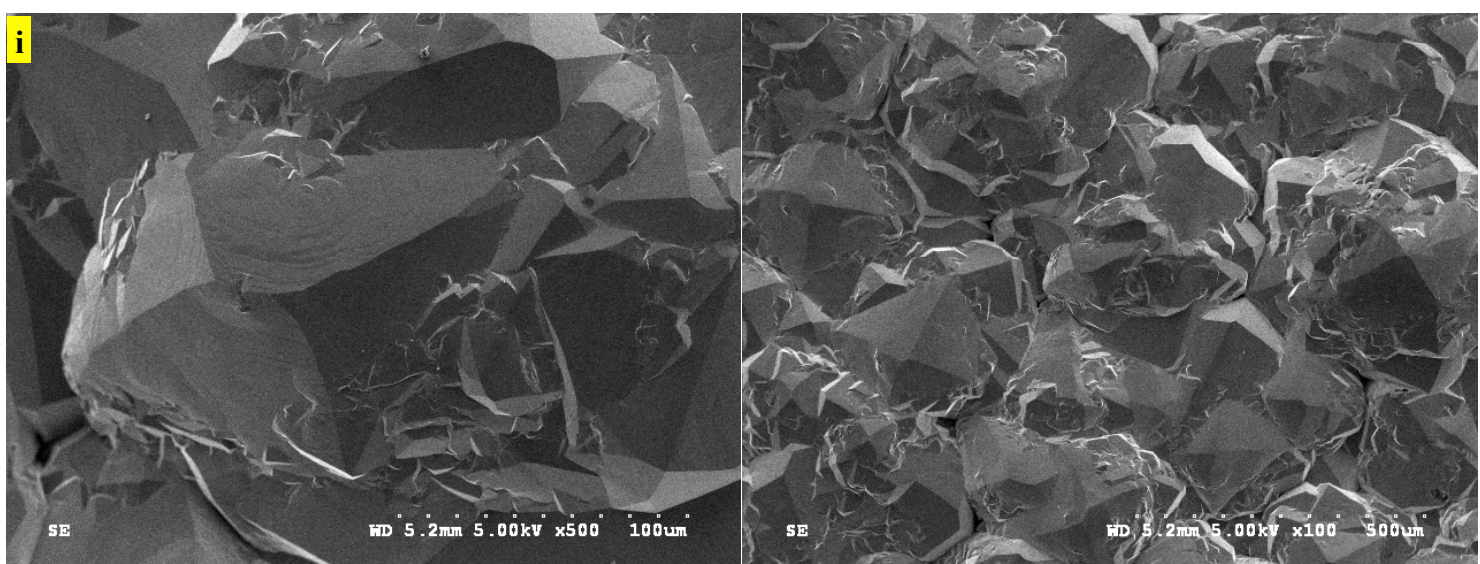

Figure 5.14 Scanning electron microscope diagrams for sample i (Current density at $500 \mathrm{~A} / \mathrm{m}^{2}, 24 \mathrm{~h}$ ) 


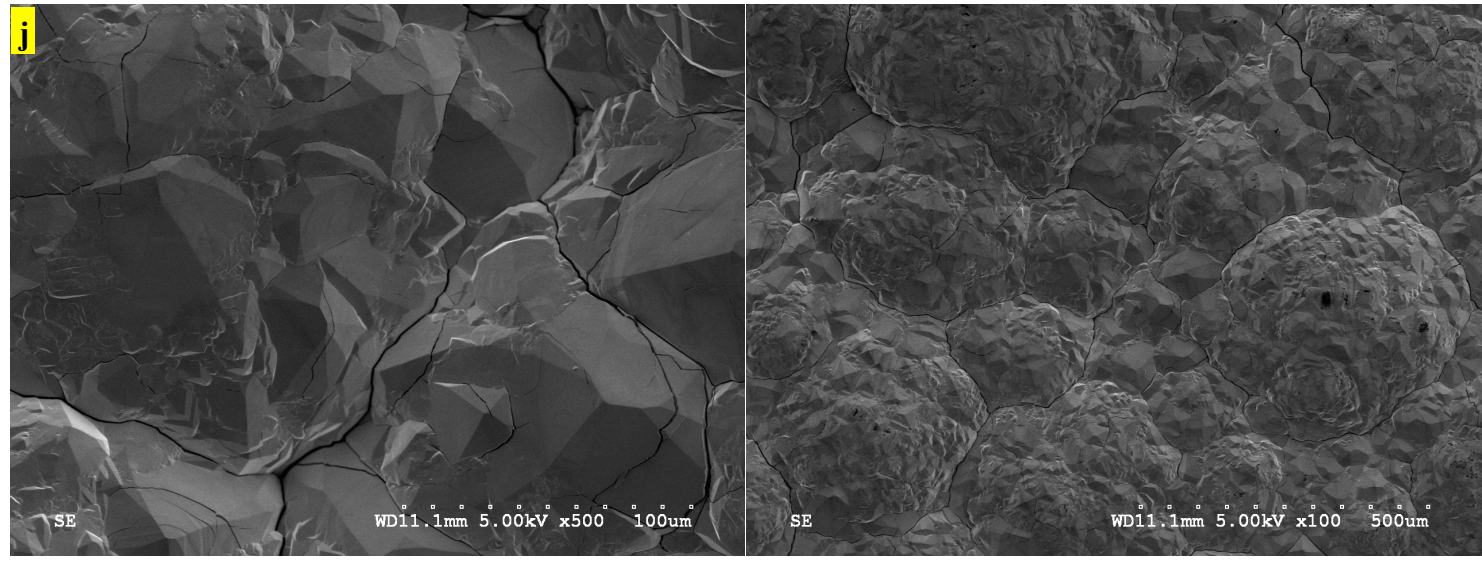

Figure 5.15 Scanning electron microscope diagrams for sample j (Current density at $750 \mathrm{~A} / \mathrm{m}^{2}, 16 \mathrm{~h}$ )

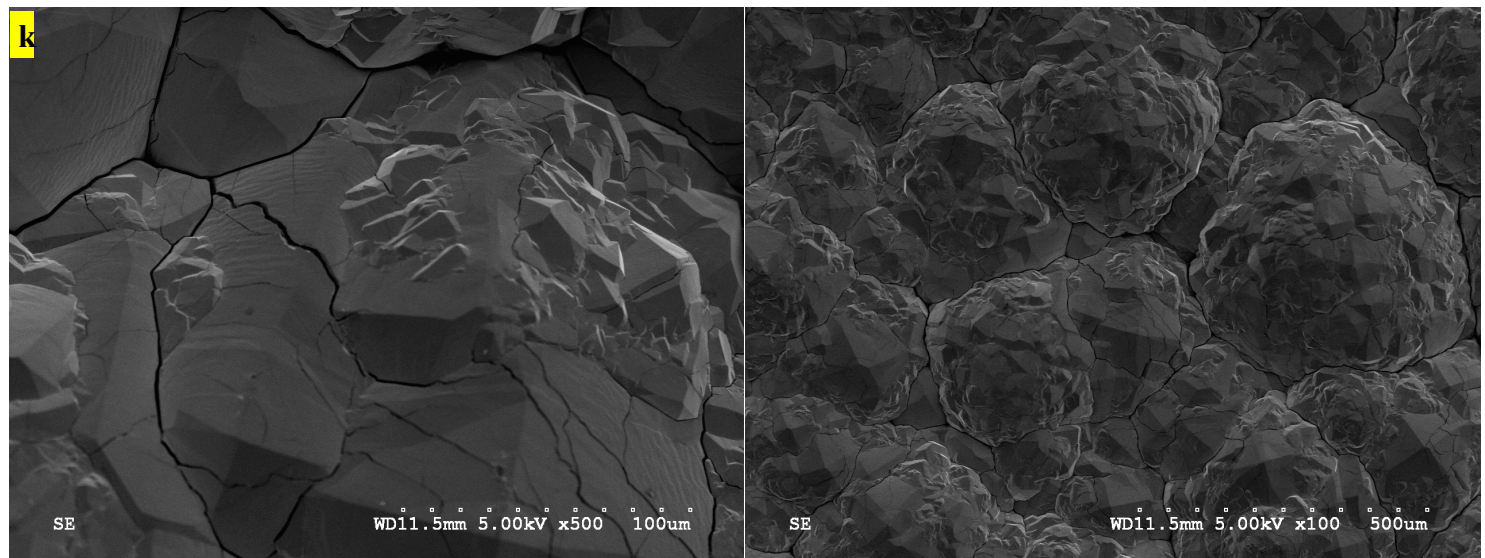

Figure 5.16 Scanning electron microscope diagrams for sample $k$ (Current density at $1000 \mathrm{~A} / \mathrm{m}^{2}, 12 \mathrm{~h}$ )

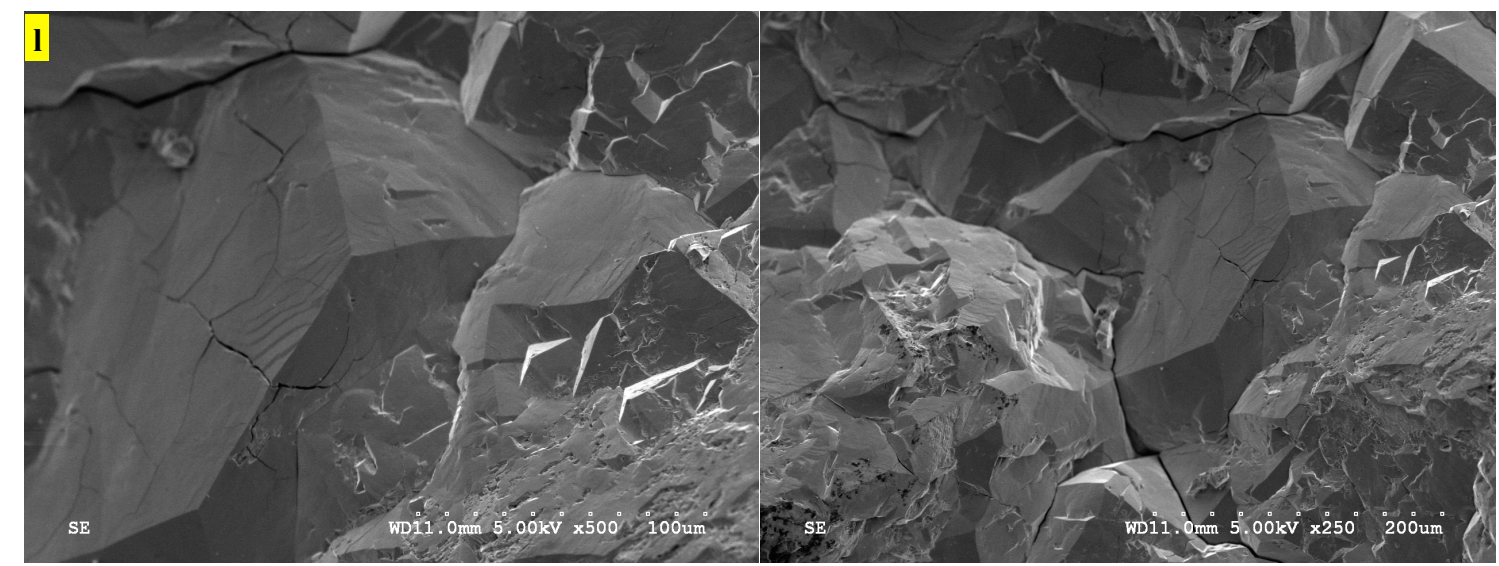

Figure 5.17 Scanning electron microscope diagrams for sample I (Current density at $500 \mathrm{~A} / \mathrm{m}^{2}, 48 \mathrm{~h}$ ) 


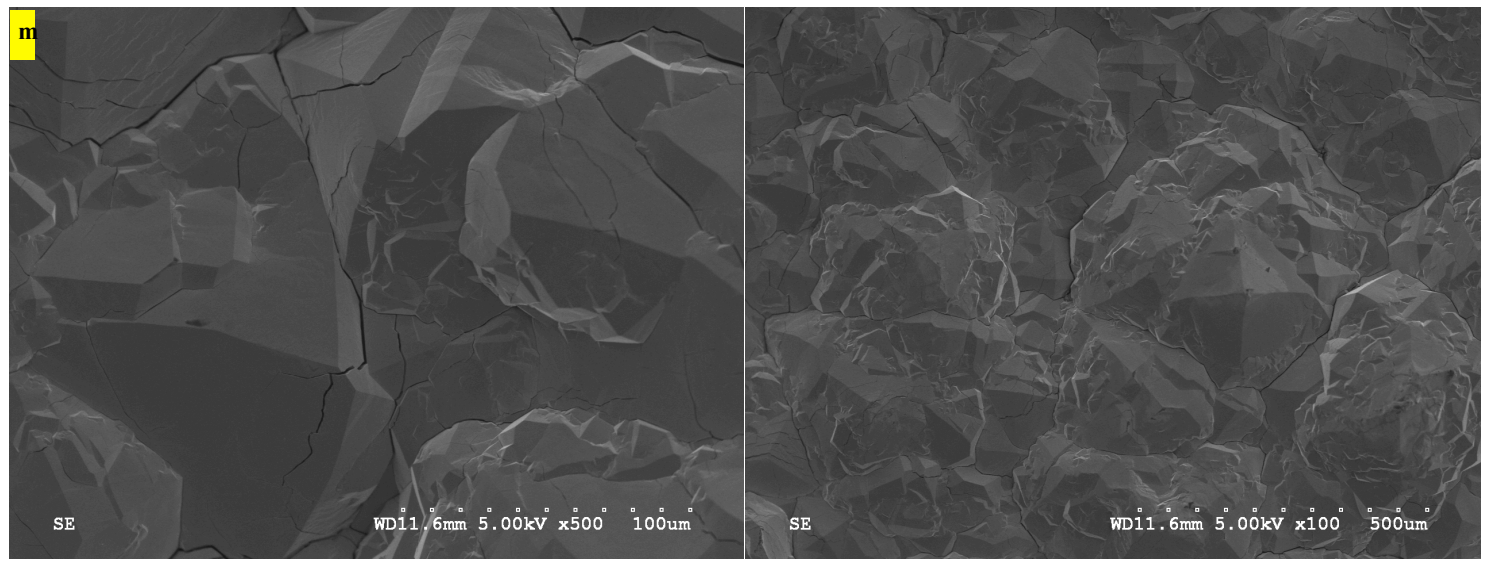

Figure 5.18 Scanning electron microscope diagrams for sample m (Current density at $500 \mathrm{~A} / \mathrm{m}^{2}, 24 \mathrm{~h}$, cathode $2^{\text {nd }}$ time use)

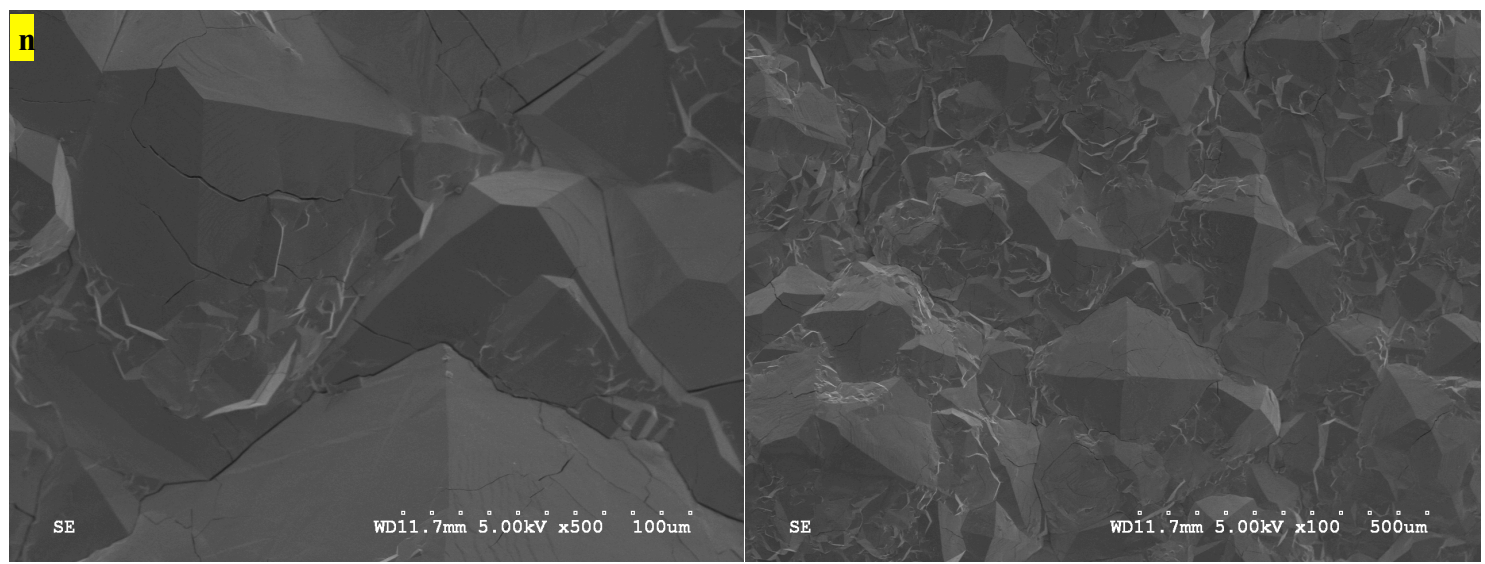

Figure 5.19 Scanning electron microscope diagrams for sample n (Current density at $500 \mathrm{~A} / \mathrm{m}^{2}, 24 \mathrm{~h}$, cathode $3^{\text {rd }}$ time use)

\subsection{Summary}

The following points can be summarized from this work:

(1) The purity of manganese deposit did not change significantly in the presence of the impurities and an addition of $0.15-5.0 \mathrm{mg} / 1 \mathrm{Zn}^{2+}$ in the catholyte in the manganese deposition cell increases the cathodic current efficiency. 
(2) The manganese deposits were confirmed to be the $\alpha$-Mn metal phase. The quality and the purity of the deposited manganese decreased as the impurity concentration increased. The surface morphology also varied with the impurity concentration.

(3) The impurity contamination increased with increase in the impurity concentrations in the catholyte. Contamination was found to be least in the case of $\mathrm{Ni}^{2+}$ and greatest in the case of $\mathrm{Zn}^{2+}$. The increasing rate of $\mathrm{Cd}^{2+}$ deposition in the manganese deposit was the highest of the impurities tested.

(4) Current density, deposition time and cathode usage frequency could affect the current efficiency, specific energy consumption and surface morphology. With increasing the current density, the cathodic current efficiency first increased, reached a maximum value and then decreased. With increasing deposition time from 24 hours to 48 hours, the manganese current efficiency decreased and the deposit became more dendritic. The more times the cathode was used, the lower the current efficiency, which indicated that the lifetime of the cathode for manganese electrorefining was short. 


\section{Chapter 6: Conclusions and Recommendations}

The three objectives defined for this research program have been accomplished. The conclusions from this study and how they correspond to the research objectives will be discussed in this chapter. The conclusions will be continued by recommendations for future work.

\subsection{Conclusions}

The following overall conclusions can be summarized from this work:

(1) For the physical properties of the electrolyte, the density increases when increasing the concentrations of the ammonium chloride and manganese chloride at room temperature. The maximum electrical conductivity is obtained with high concentrations of ammonium chloride and high temperature. Viscosity is minimized by high temperature and by low concentrations of manganese chloride concentration. In general, electrorefining should be carried out under conditions of high electrical conductivity and low viscosity.

(2) For the cementation tests by manganese powder, the descending order of selectivity on the manganese powder is: $\mathrm{Cu}>\mathrm{Cd}>\mathrm{Ni}>\mathrm{Co}>\mathrm{Cr}>\mathrm{Zn}$. It is better to control the $\mathrm{pH}$ at 5.5 and reaction time at 30 45 minutes for higher removal rates for the impurities. But it is not suitable to get high purity manganese, as there are still plenty of impurities in the solution after purification.

(3) $\mathrm{pH}$ and resin dosages can both affect the equilibrium test results for these two resins. Lewatit ${ }^{\circ}$ MDS TP220 showed a superior performance in comparison to Purolite S930Plus in removing the ionic impurities from synthetic solutions. 
(4) For the column tests, heavy metals, such as copper, nickel, cobalt, zinc and cadmium can be effectively and selectively removed from an acidic manganese chloride solution using the chelating resin Lewatit ${ }^{\circledR}$ MDS TP220, and the descending order of selectivity on the chelating resin is $\mathrm{Cu}>\mathrm{Co} \sim \mathrm{Zn}>\mathrm{Ni}>\mathrm{Cd}>\mathrm{Mn}$. The obtained results for $\mathrm{TP} 220$ resin revealed a classic behavior, showing that the increase of the used resin quantity and, implicitly, of the bead height results in an increase of the breakthrough time. But for the Purolite S930Plus resin, it was only effective for copper removal.

(5) The purity of manganese deposit did not change significantly in the presence of the impurities and an addition of $0.15-5.0 \mathrm{mg} / 1 \mathrm{Zn}^{2+}$ in the catholyte in the manganese deposition cell increases the cathodic current efficiency.

(6) The manganese deposits were confirmed to be the $\alpha$-Mn metal phase. The quality and the purity of the deposited manganese decreased as the impurity concentration increased. The surface morphology also varied with the impurity concentration.

(7) The impurity contamination increased with increase in the impurity concentrations in the catholyte. Contamination was found to be least in the case of $\mathrm{Ni}^{2+}$ and greatest in the case of $\mathrm{Zn}^{2+}$. The increasing rate of $\mathrm{Cd}^{2+}$ deposition in the manganese deposit was the highest of the impurities tested.

(8) Current density, deposition time and cathode usage frequency could affect the current efficiency, specific energy consumption and surface morphology. With increasing the current density, the cathodic current efficiency first increased, reached a maximum value and then decreased. With increasing deposition time from 24 hours to 48 hours, the manganese current efficiency decreased and the deposit became more dendritic. The 
more times the cathode was used, the lower the current efficiency, which indicated that the lifetime of the cathode for manganese electrorefining was short.

\subsection{Recommendations for Future Work}

(1) The column size and the flow rate of the solution are also one of the important parameters to obtain the quantitative uptake of metal ion. All the tests performed in this thesis used an electrolyte-loading rate of $1 \mathrm{~mL} / \mathrm{min}$. The effect of column size and flow rate on the separation efficiency should be investigated further.

(2) Elution is required in developing a commercial process for separating heavy metals from acidic manganese chloride solutions. So the elution studies should be examined in the future work.

(3) Fundamental kinetics of electrochemical reduction of manganese (II) in the chloride system should be investigated to elucidate the characteristics and mechanisms.

(4) Different cathode materials and anion membranes should be selected and tested to improve the current efficiency and manganese purity.

(5) The surface condition of the cathode after repeated use should be investigated to determine the reason for its short lifetime. Better treatment methods should be explored to improve the behavior of used cathode. 


\section{Bibliography}

[1] M. P. D. Howe, H. M. Malcolm, and D. S. Dobson, "Manganese and Its Compound: Environmental Aspect," World Heal. Organ. Geneva, 2004.

[2] A. A. Baba, L. Ibrahim, F. A. Adekola, R. B. Bale, M. K. Ghosh, A. R. Sheik, S. R. Pradhan, O. S. Ayanda, I. O. Folorunsho, and A. A. Baba, "Hydrometallurgical Processing of Manganese Ores: A Review," J. Miner. Mater. Charact. Eng., vol. 2, pp. 230-247, 2014.

[3] S. Tajima, N. Baba, and T. Midorikawa, "Electrodeposition of high purity manganese from low temperature chloride electrolyte," J. Appl. Electrochem., vol. 6, no. 3, pp. 243$250,1976$.

[4] J. Lu, D. Dreisinger, and T. Glück, "Manganese electrodeposition - A literature review," Hydrometallurgy, vol. 141. pp. 105-116, 2014.

[5] J. H. Jacobs and P. E. Churchward, "Electrowinning of Manganese from Chloride Electrolytes," J. Electrochem. Soc., vol. 94, no. 3, p. 108, 1948.

[6] L. Kozin, F. Manilevich, and N. Mashkova, "Electrochemical refining of manganese to high purity," Russ. J. Appl. Chem., vol. 71, no. 3, 1998.

[7] J. L. Huisman, G. Schouten, and C. Schultz, "Biologically produced sulphide for purification of process streams, effluent treatment and recovery of metals in the metal and mining industry," Hydrometallurgy, vol. 83, no. 1-4, pp. 106-113, 2006. 
[8] A. E. Lewis, "Review of metal sulphide precipitation," Hydrometallurgy, vol. 104, no. 2, pp. 222-234, 2010.

[9] N. (1985) Holleman, Arnold F.; Wiberg, Egon; Wiberg, "Mangan\&quot;. Lehrbuch der Anorganischen Chemie (in German) (91-100 ed.)," Walter Gruyter. pp. 1110-1117.

[10] W. M. Haynes, "CRC Handbook of Chemistry and Physics."

[11] K. Lohbeck, H. Haferkorn, W. Fuhrmann, and N. Fedtke, "Manganese and Manganese Alloys," Ullmann's Encycl. Ind. Chem., no. group 12, pp. 413-454, 2005.

[12] R. B. Temple and G. W. Thickett, "The formation of manganese in molten sodium nitrite."

[13] J. G. Kaufman, “Aluminum Alloys,” in Handbook of Materials Selection, 2007, pp. 89134.

[14] K. Hagelstein, "Globally sustainable manganese metal production and use," J. Environ. Manage., vol. 90, no. 12, pp. 3736-3740, 2009.

[15] M. Uchikoshi, K. Kawai, M. Sasagaki, K. Mimura, and M. Isshiki, "Purification of Manganese Chloride with Chelating Resin Containing Iminodiacetate Groups in Ammonium Chloride Solution," Mater. Trans., vol. 49, no. 2, pp. 284-288, 2008.

[16] L. A. Corathers, “2013 Minerals Yearbook manganese,” 2016.

[17] W. Zhang and C. Y. Cheng, "Manganese metallurgy review . Part II : Manganese 109 
separation and recovery from solution," vol. 89, pp. 160-177, 2007.

[18] M. Isshiki, K. Mimura, and M. Uchikoshi, "Preparation of high purity metals for advanced devices," Thin Solid Films, vol. 519, no. 24, pp. 8451-8455, 2011.

[19] J. Jandová, K. Lisá, H. Vu, and F. Vranka, "Separation of copper and cobalt-nickel sulphide concentrates during processing of manganese deep ocean nodules."

[20] a. H. M. Veeken, S. de Vries, a. van der Mark, and W. H. Rulkens, "Selective Precipitation of Heavy Metals as Controlled by a Sulfide-Selective Electrode,” Sep. Sci. Technol., vol. 38, no. 1, pp. 1-19, 2003.

[21] F. Fu and Q. Wang, "Removal of heavy metal ions from wastewaters: A review," $J$. Environ. Manage., vol. 92, no. 3, pp. 407-418, 2011.

[22] W. Zhang, C. Y. Cheng, and Y. Pranolo, "Investigation of methods for removal and recovery of manganese in hydrometallurgical processes," Hydrometallurgy, vol. 101, no. 1, pp. 58-63, 2010.

[23] Z. I. K. S.J. Clark *, J.D. Donaldson, "Heavy metals in the environment. Part VI: Recovery of cobalt values from spent cobalt/manganese bromide oxidation catalysts," Hydrometallurgy, pp. 381-392, 1996.

[24] N. KONGSRICHAROERN and C. POLPRASERT, "Electrochemical precipitation of chromium (Cr) from an electroplating wastewater," Water Sci. Technol., vol. 31, no. 9, pp. 109-117, 1995. 
[25] Geetha Varma.V1, Dr.Ram Karan Singh2, and and Vaishali Sahu3, "A comparative study on the removal of heavy metals by adsorption using fly ash and sludge: A review," Int. J. Appl. or Innov. Eng. Manag.

[26] A. Bhatnagar and A. K. Minocha, "Conventional and non-conventional adsorbents for removal of pollutants from water - A review," Indian J. Chem. Technol., vol. 13, pp. 203217, 2006.

[27] S. Iijima, "Helical microtubules of graphitic carbon," Nature, vol. 354, no. 6348, pp. 5658, Nov. 1991.

[28] M. Bansal, D. Singh, and V. K. Garg, "A comparative study for the removal of hexavalent chromium from aqueous solution by agriculture wastes' carbons," J. Hazard. Mater., vol. 171, no. 1, pp. 83-92, 2009.

[29] S. Y. Kang, J. U. Lee, S. H. Moon, and K. W. Kim, "Competitive adsorption characteristics of $\mathrm{Co} 2+, \mathrm{Ni} 2+$, and $\mathrm{Cr} 3+$ by IRN-77 cation exchange resin in synthesized wastewater," Chemosphere, vol. 56, no. 2, pp. 141-147, 2004.

[30] a Yuchi, T. Sato, Y. Morimoto, H. Mizuno, and H. Wada, "Adsorption mechanism of trivalent metal ions on chelating resins containing iminodiacetic Acid groups with reference to selectivity.," Anal. Chem., vol. 69, no. 15, pp. 2941-4, 1997.

[31] C. V. Diniz, V. S. T. Ciminelli, and F. M. Doyle, "The use of the chelating resin Dowex M-4195 in the adsorption of selected heavy metal ions from manganese solutions," 
Hydrometallurgy, vol. 78, no. 3-4, pp. 147-155, Aug. 2005.

[32] F. D. Mendes and A. H. Martins, "Selective sorption of nickel and cobalt from sulphate solutions using chelating resins," Int. J. Miner. Process., vol. 74, no. 1-4, pp. 359-371, Nov. 2004.

[33] V. I. Kuz'min and D. V. Kuz'min, "Sorption of nickel and copper from leach pulps of low-grade sulfide ores using Purolite S930 chelating resin," Hydrometallurgy, vol. 141, pp. 76-81, Jan. 2014.

[34] A. Wołowicz and Z. Hubicki, "The use of the chelating resin of a new generation Lewatit MonoPlus TP-220 with the bis-picolylamine functional groups in the removal of selected metal ions from acidic solutions," Chem. Eng. J., vol. 197, pp. 493-508, 2012.

[35] V. I. Kuz’Min and D. V. Kuz’Min, “Sorption of nickel and copper from leach pulps of low-grade sulfide ores using Purolite S930 chelating resin," Hydrometallurgy, vol. 141, pp. 76-81, 2014.

[36] P. Littlejohn and J. Vaughan, "Selectivity of commercial and novel mixed functionality cation exchange resins in mildly acidic sulfate and mixed sulfate-chloride solution," Hydrometallurgy, vol. 121-124, pp. 90-99, Jun. 2012.

[37] K. C. Nathsarma and N. Devi, "Separation of $\mathrm{Zn}(\mathrm{II})$ and $\mathrm{Mn}$ (II) from sulphate solutions using sodium salts of D2EHPA, PC88A and Cyanex 272," Hydrometallurgy, vol. 84, no. 3-4, pp. 149-154, 2006. 
[38] C. Y. Cheng, "Purification of synthetic laterite leach solution by solvent extraction using D2EHPA," Hydrometallurgy, vol. 56, no. 3, pp. 369-386, 2000.

[39] R. K. Biswas, M. A. Hanif, and M. F. Bari, "Kinetics of forward extraction of manganese(II) from acidic chloride medium by D2EHPA in kerosene using the single drop technique," Hydrometallurgy, vol. 42, no. 3, pp. 399-409, Oct. 1996.

[40] H.-Z. Long, L.-Y. Chai, W.-Q. Qin, and S.-H. Tang, "Solvent extraction of zinc from zinc sulfate solution," J. Cent. South Univ. Technol, vol. 17, pp. 760-764, 2010.

[41] B. K. Tait, "Cobalt-nickel separation: the extraction of cobalt(II) and nickel(II) by Cyanex 301, Cyanex 302 and Cyanex 272," Hydrometallurgy, vol. 32, no. 3, pp. 365-372, Apr. 1993.

[42] N. B. Devi, K. C. Nathsarma, and V. Chakravortty, "Extraction and separation of Mn(II) and $\mathrm{Zn}(\mathrm{II})$ from sulphate solutions by sodium salt of Cyanex 272," Hydrometallurgy, vol. 45, no. 1-2, pp. 169-179, May 1997.

[43] A. L. Salgado, A. M. . Veloso, D. D. Pereira, G. S. Gontijo, A. Salum, and M. B. Mansur, "Recovery of zinc and manganese from spent alkaline batteries by liquid-liquid extraction with Cyanex 272,” J. Power Sources, vol. 115, no. 2, pp. 367-373, 2003.

[44] P. . Cole, "The introduction of solvent-extraction steps during upgrading of a cobalt refinery," Hydrometallurgy, vol. 64, no. 1, pp. 69-77, Apr. 2002.

[45] N. Begum, F. Bari, S. Baharin Jamaludin, and K. Hussin, "Solvent extraction of copper, 
nickel and zinc by Cyanex 272," Int. J. Phys. Sci., vol. 7, no. 22, pp. 2905-2910, 2012.

[46] N. V Thakur, D. V Jayawant, N. S. Iyer, and K. S. Koppiker, "Separation of neodymium from lighter rare earths using alkyl phosphonic acid, PC 88A," Hydrometallurgy, vol. 34, pp. 99-108, 1993.

[47] M.-S. Lee, G.-S. Lee, J.-Y. Lee, S.-D. Kim, and J.-S. Kim, "Solvent Extraction of Sm from Chloride Solution with PC88A and Saponified PC88A."

[48] N. V. Thakur, "Extraction studies of base metals ( $\mathrm{Mn}, \mathrm{Cu}, \mathrm{Co}$ and $\mathrm{Ni}$ ) using the extractant 2-ethylhexyl 2-ethylhexyl phosphonic acid, PC 88A," Hydrometallurgy, vol. 48, no. 1, pp. 125-131, Mar. 1998.

[49] B. R. Reddy, C. Parija, and P. V. R. B. Sarma, "Processing of solutions containing nickel and ammonium sulphate through solvent extraction using PC-88A," Hydrometallurgy, vol. 53, pp. 11-17, 1999.

[50] D. B. Dreisinger and W. C. Cooper, "The solvent extraction separation of cobalt and nickel using 2-ethylhexylphosphonic acid mono-2-ethylhexyl ester," Hydrometallurgy, vol. 12, no. 1, pp. 1-20, Feb. 1984.

[51] J. E. Lewis, P. H. Scaife, and D. A. J. Swinkels, "Electrolytic manganese metal from chloride electrolytes. I. Study of deposition conditions," J. Appl. Electrochem., vol. 6, no. 3, pp. 199-209, May 1976.

[52] R. M. Freitas, T. A. G. Perilli, A. C. Q. Ladeira, R. M. Freitas, T. A. G. Perilli, and A. C. 
Q. Ladeira, "Oxidative Precipitation of Manganese from Acid Mine Drainage by Potassium Permanganate," J. Chem., vol. 2013, pp. 1-8, 2013.

[53] W. Zhang and C. Y. Cheng, "Manganese metallurgy review. Part I: Leaching of ores/secondary materials and recovery of electrolytic/chemical manganese dioxide," Hydrometallurgy, vol. 89, pp. 137-159, 2007.

[54] M. Harris, D. M. Meyer, and Auerswald K., "The production of electrolytic manganese in South Africa," South. African Inst. Min. Metall., vol. 77, no. 7, pp. 137-142, 1977.

[55] P. Wei, O. E. Hileman, M. R. Bateni, X. Deng, and A. Petric, "Manganese deposition without additives," Surf. Coatings Technol., vol. 201, no. 18, pp. 7739-7745, 2007.

[56] C. . Mantell, “Anodes for the electrowinning of Mn. US Patent No. 2340400.” 15-Jul1969.

[57] M. C. L. Ferment George R, “Electrowinning manganese,” US3455799 A, 1969.

[58] V. de F. C. L. José Antonio Mendonça de Araujoa, Maria das Mercês Reis de Castrob, "Reuse of furnace fines of ferro alloy in the electrolytic manganese production," Hydrometallurgy, vol. 84, no. 3-4, pp. 204-210, 2006.

[59] V. N. Zosimovich, D.P., Shvab, N.A., Belinskii, "Electrodeposition of manganese on a rotating electrode in the presence of impurities," Sov. J. Electrochem., vol. 3, pp. 13331335. 
[60] P. Ilea, I.-C. Popescu, M. Urdă, and L. Oniciu, "The electrodeposition of manganese from aqueous solutions of MnSO4. IV: Electrowinning by galvanostatic electrolysis," Hydrometallurgy, vol. 46, no. 1-2, pp. 149-156, 1997.

[61] R.S. Dean, "Electrolytic Manganese and Its Alloy,” Ronald Press. New York.

[62] I. E. Lewis, P. H. Scaife, and D. A. J. Swinkels, "Electrolytic manganese metal from chloride electrolytes. II. Effect of additives," J. Appl. Electrochem., vol. 6, no. 5, pp. 453$462,1976$.

[63] B. B. Yanitskii, I.V., Stul'Pinas, "Electrodeposition of manganese with increased current efficiency," J. Appl. Chem. USSR (English Transl. Ed., vol. 31, pp. 243-247.

[64] P. Wei, O. E. Hileman, M.-R. Bateni, X. Deng, and A. Petric, "Manganese deposition without additives," Surf. Coatings Technol., vol. 201, no. 18, pp. 7739-7745, 2007.

[65] 1984. Coleman, T., Griffin, R., "Method for electrodepositing metallic manganese," US Pat. No. 4478697.

[66] 1 Subrat Kumar Padhy, 1,2B. C. Tripathy, 1 I.N. Bhattacharya, and B.K. Mishra, "Electrowinning of manganese from sulphate solutions in the presence of organic additives," Hydro2014 - 7th Int. Symp., 2014.

[67] R. G. K. J.H. Jacobs, J.W. Hunter, W.H. Yaroll, P.E. Churchward, "Operations of electrolytic manganese pilot plant at Boulder City," Tech. Rep. 463, United States Dep. Inter. Bur. Mines, Boulder City, USA. 
[68] L. F. Kozin, N. V Mashkova, F. D. Manilevich, and B. I. Danil 'tsev, "Electrochemical Behavior of Manganese in ChlorideBromideAmmonium Electrolytes," ISSN Russ. J. Appl. Chem. Orig. Russ. Text +I. Danil'tsev Zhurnal Prikl. Khimii, vol. 80, no. 5, pp. $1070-4272,2007$.

[69] Q. Wei, X. Ren, J. Du, S. Wei, and S. Hu, "Study of the electrodeposition conditions of metallic manganese in an electrolytic membrane reactor," Miner. Eng., vol. 23, no. 7, pp. $578-586,2010$.

[70] A. Sulcius, E. Griskonis, K. Kantminiene, and N. Zmuidzinaviciene, "Influence of different electrolysis parameters on electrodeposition of $\gamma$ - and $\alpha$-Mn from pure electrolytes - a review with special reference to Russian language literature," Hydrometallurgy, vol. 137, pp. 33-37, 2013.

[71] R. Priestner and a. C. Steel, “Technical note,” Met. Technol., vol. 3, no. 1, pp. 580-580, 1976.

[72] D. C. Price and W. G. Davenport, "Densities, electrical conductivities and viscosities of $\mathrm{CuSO} 4 / \mathrm{H} 2 \mathrm{SO} 4$ solutions in the range of modern electrorefining and electrowinning electrolytes," Metall. Trans. B, vol. 11, no. 1, pp. 159-163, Mar. 1980.

[73] A. Solutions and B. Fluids, "Concentrative properties of aqueous solutions: density, refractive index, freezing point depression, and vicosity," pp. 1-27.

[74] R. Flüssigkeiten, "International critical tables: viscosity and fluidity." 
[75] a. Deepatana, J. a. Tang, and M. Valix, "Comparative study of chelating ion exchange resins for metal recovery from bioleaching of nickel laterite ores," Miner. Eng., vol. 19, no. 12, pp. 1280-1289, Sep. 2006.

[76] J. J. Lingane and R. Karplus, "New Method for Determination of Manganese," Ind. Eng. Chem. Anal. Ed., vol. 18, no. 3, pp. 191-194, Mar. 1946.

[77] B. Y. R S Mcbride, “The standardization of potassium permanganate solution by sodium oxalate," J. Am. Chem. Soc. 191234 (4), 393-416.

[78] R. W. Lew, "The removal of cobalt from zinc sulphate electrolyte using the copperantimony process," no. January, 1994.

[79] A. B. Pérez-Marín, V. M. Zapata, J. F. Ortuño, M. Aguilar, J. Sáez, and M. Lloréns, "Removal of cadmium from aqueous solutions by adsorption onto orange waste," $J$. Hazard. Mater., vol. 139, no. 1, pp. 122-131, 2007.

[80] H. K. Boparai, M. Joseph, and D. M. O'Carroll, "Cadmium (Cd2+) removal by nano zerovalent iron: surface analysis, effects of solution chemistry and surface complexation modeling," Environ. Sci. Pollut. Res., vol. 20, no. 9, pp. 6210-6221, Sep. 2013.

[81] IRINA BLEOTUa, "Removal of copper from diluted aqueous solutions using an iminodiacetic acid chelating ion-exchange resin in a fixed-bed column," Stud. Univ. Babes-Bolyai Ser. Chem., vol. 2015, no. 3, pp. 163-172, 2015.

[82] J. Lu, D. Dreisinger, and T. Glück, "Electrolytic manganese metal production from 
manganese carbonate precipitate," Hydrometallurgy, vol. 161, pp. 45-53, 2016. 


\section{Appendices}

\section{Appendix A Calibrations for Conductivity Meter and Viscometer}

\section{Conductivity meter}

The measured conductivity values for the standard solutions at different temperatures are shown in Table A.1. For the $1413 \mu \mathrm{S} / \mathrm{cm}$ standard solution, the manufacturer's values printed on the bottle label were compared with the experimental values. It was found that the deviation is very small and the measured values are slightly higher than the reported one. This is probably due to the experimental error.

Table A.1 Conductivity values for the standard solutions at different temperatures

\begin{tabular}{|c|c|c|c|}
\hline & Measured $(\boldsymbol{\mu S} / \mathbf{c m})$ & Reported( $\boldsymbol{\mu S} / \mathbf{c m})$ & Error(\%) \\
\hline $25^{\circ} \mathrm{C}$ & 1420 & 1413 & 0.495 \\
\hline $20^{\circ} \mathrm{C}$ & 1278 & 1273 & 0.393 \\
\hline $15^{\circ} \mathrm{C}$ & 1145 & 1141 & 0.592 \\
\hline $10^{\circ} \mathrm{C}$ & 1020 & 1014 & 0.786 \\
\hline $5^{\circ} \mathrm{C}$ & 898 & 891 & 0.906 \\
\hline 0
\end{tabular}

\section{Viscometer}


For the viscometer, the model is LVDV-III. It was calibrated with the standard fluid 5000 (viscosity at $5040 \mathrm{cp}$ ) at the $25^{\circ} \mathrm{C}$. Low speed rate $5 \mathrm{rpm}$ was chosen due to the relatively high standard solution viscosity.

Full scale viscosity range $(\mathrm{cp})=\mathrm{TK} * \mathrm{SMC} *(1000 / \mathrm{RPM})$

$$
=0.09373 * 32 *(1000 / 5)=5998.72 \mathrm{cp}
$$

(1) The viscosity is accurate to (+/-) $59.9872 \mathrm{cp}$

(2) The viscosity standard fluid is $5040 \mathrm{cp}$. Its accuracy is (+/-) $1 \%$ of $5040 \mathrm{cp}$ or (+/-) $50.40 \mathrm{cp}$

(3) The total allowable error is $59.9872+50.4=(+/-) 110.3872 \mathrm{cp}$

(4) The range for the accuracy is $(4930,5150) \mathrm{cp}$

When the value was stable, it was recorded. The viscosity for the standard fluid is 5110 cp and the torque is $85.2 \%$. It was in the range of the accuracy.

\section{Appendix B XRD Patterns}




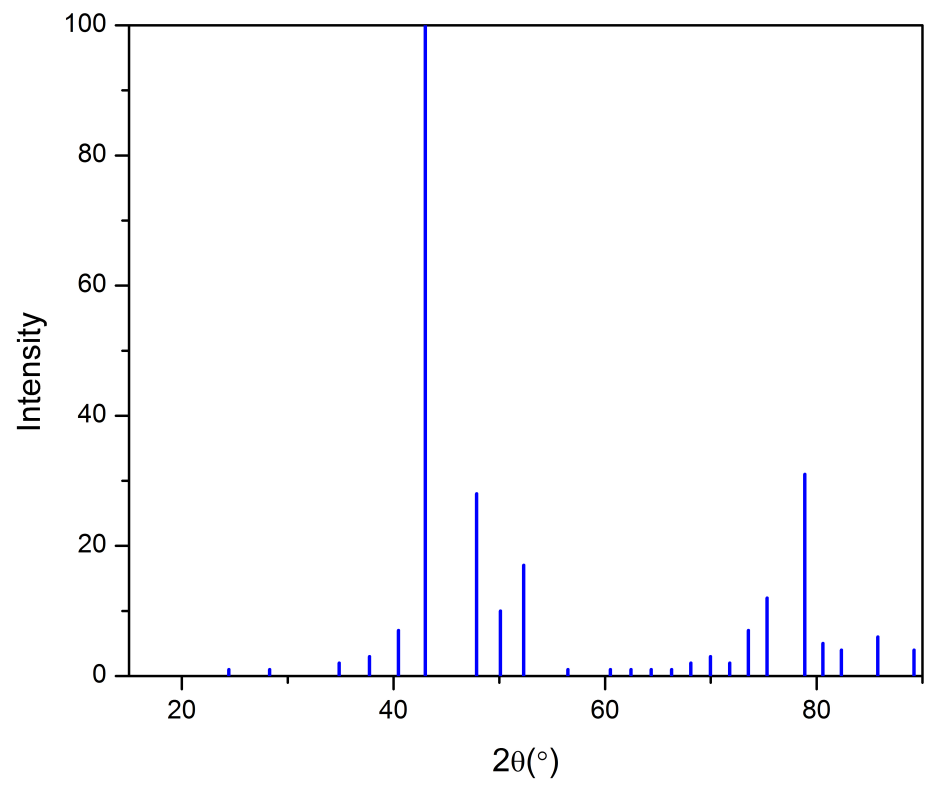

Figure B.1 XRD pattern of metallic $\alpha-M n$

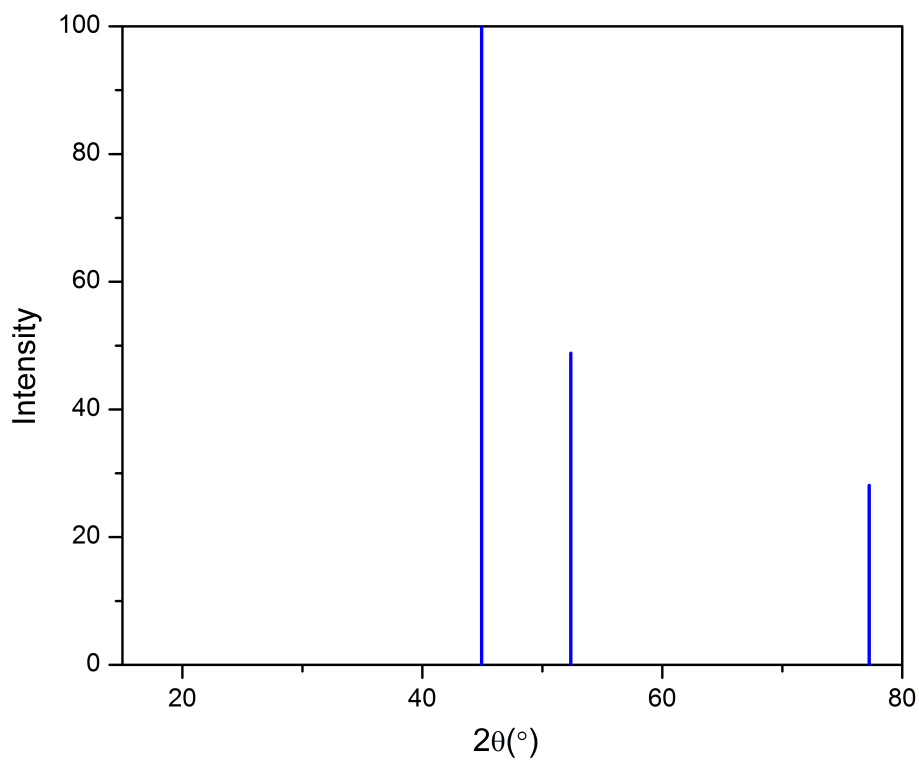

Figure B.2 XRD pattern of metallic $\gamma$-Mn 